\title{
Enhanced Component Performance Study: Turbine-Driven Pumps 1998-2018
}

Zhegang Ma

September 2019

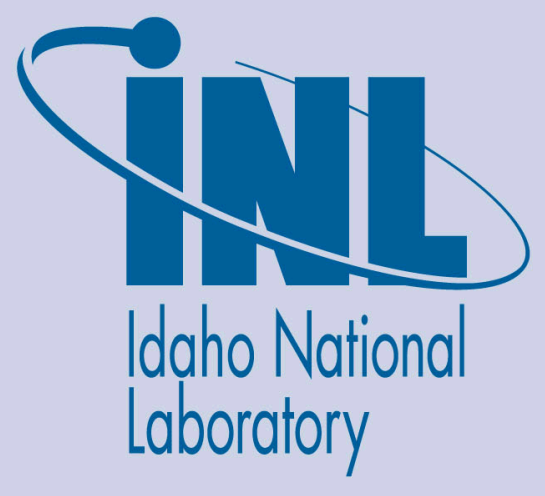

The INL is a U.S. Department of Energy National Laboratory operated by Battelle Energy Alliance 
NOTICE

This information was prepared as an account of work sponsored by an agency of the U.S. Government. Neither the U.S. Government nor any agency thereof, nor any of their employees, makes any warranty, express or implied, or assumes any legal liability or responsibility for any third party's use, or the results of such use, of any information, apparatus, product, or process disclosed herein, or represents that its use by such third party would not infringe privately owned rights. The views expressed herein are not necessarily those of the U.S. Nuclear Regulatory Commission. 


\title{
Enhanced Component Performance Study: Turbine-Driven Pumps 1998-2018
}

\author{
Zhegang Ma
}

Update Completed September 2019

Idaho National Laboratory

Risk Assessment and Management Services Department Idaho Falls, Idaho 83415

http://www.inl.gov

Prepared for the Division of Risk Assessment Office of Nuclear Regulatory Research U.S. Nuclear Regulatory Commission NRC Agreement Number NRC-HQ-60-14-D-0018 



\begin{abstract}
This report presents an enhanced performance evaluation of turbine-driven pumps (TDPs) at U.S. commercial nuclear power plants. The data used in this study are based on the operating experience failure reports from calendar year 1998 through 2018 as reported in the Institute of Nuclear Power Operations (INPO) Consolidated Events Database (ICES). The TDP failure modes considered for standby systems are failure to start (FTS), failure to run less than or equal to one hour $(\mathrm{FTR} \leq 1 \mathrm{H})$, failure to run more than one hour $(\mathrm{FTR}>1 \mathrm{H})$, and for normally running systems FTS and failure to run (FTR). An eight-hour unreliability estimate is also calculated and trended. The component reliability estimates and the reliability data are trended for the most recent 10-year period while yearly estimates for reliability are provided for the entire study period.
\end{abstract}

A highly statistically significant decreasing trend was identified in the standby TDP unavailability estimates. 
Enhanced Component Performance Study 


\section{CONTENTS}

ABSTRACT .iii

ACRONYMS ix

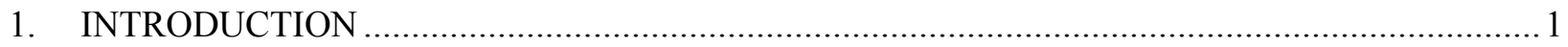

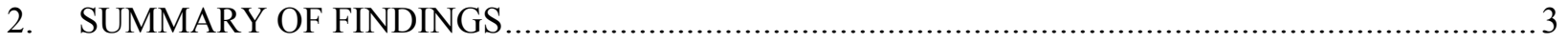

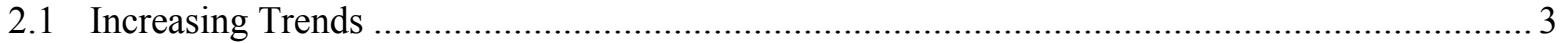

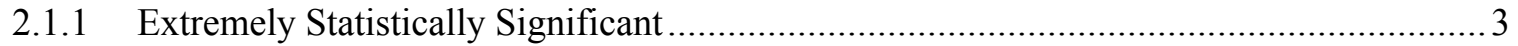

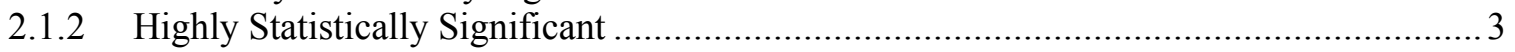

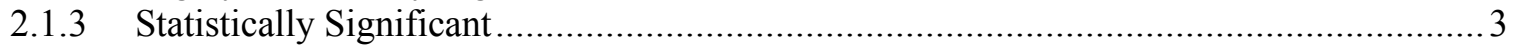

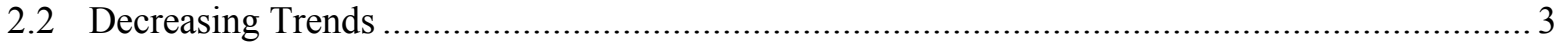

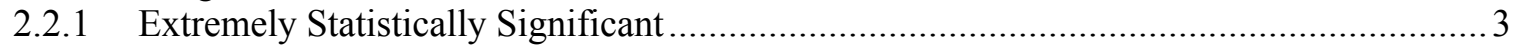

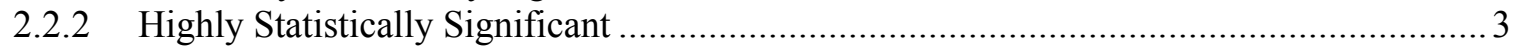

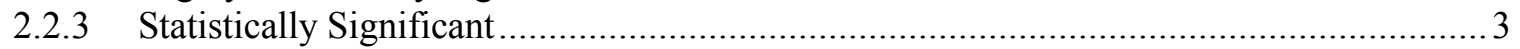

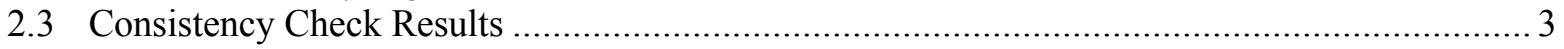

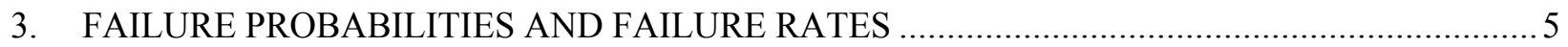

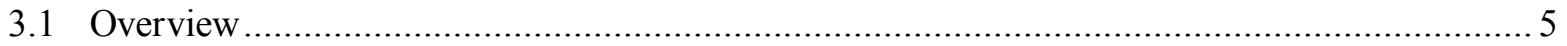

3.2 TDP Failure Probability and Failure Rate Trends .......................................................... 5

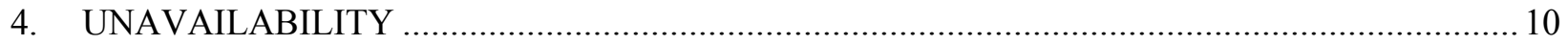

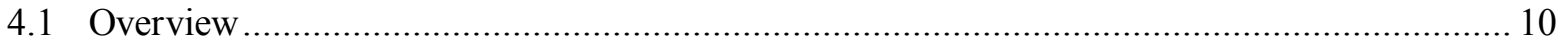

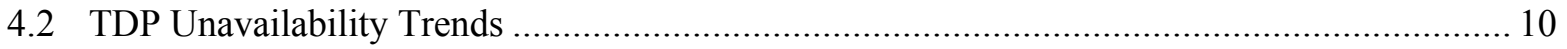

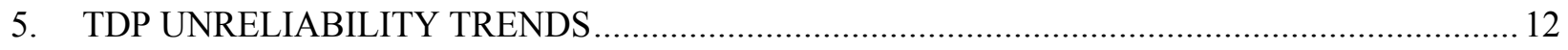

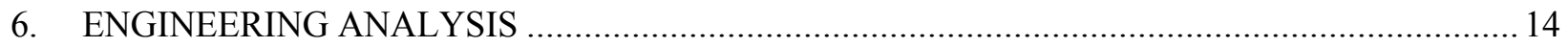

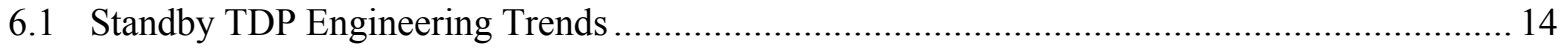

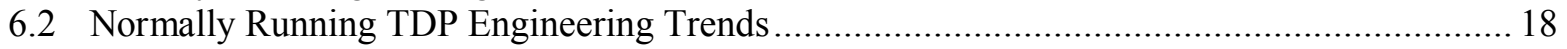

6.3 Comparison of ICES TDP Unplanned Demand Results with Industry Results ...................... 21

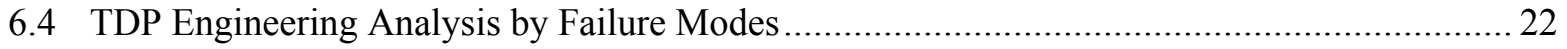

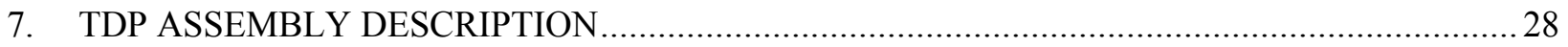

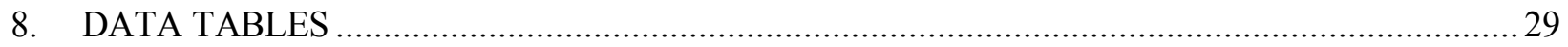

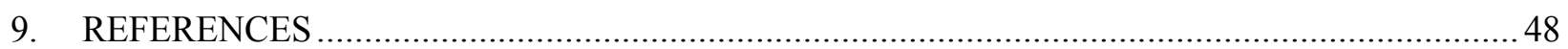




\section{FIGURES}

Figure 1. Failure probability estimate trend for standby TDP FTS................................................ 7

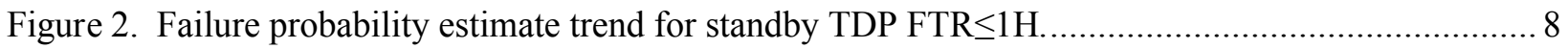

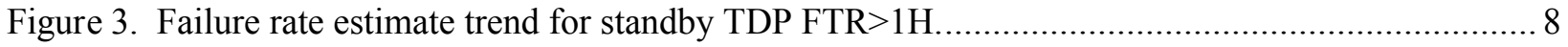

Figure 4. Failure probability estimate trend for normally running TDP FTS. .................................... 9

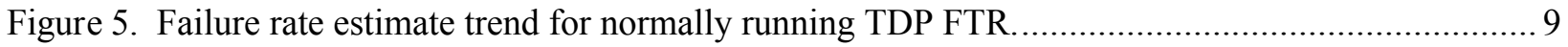

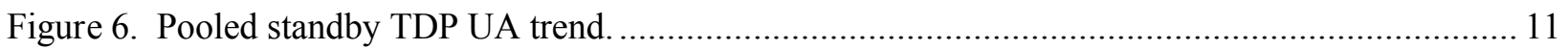

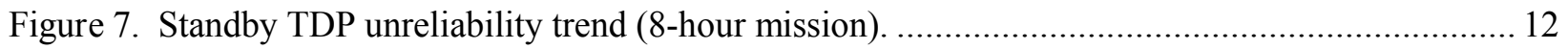

Figure 8. Normally running TDP unreliability trend (8-hour mission). ........................................... 13

Figure 9. Frequency of start demands (demands per reactor year) for standby TDPs.......................... 15

Figure 10. Frequency of run $\leq 1 \mathrm{H}$ hours (hours per reactor year) trend for standby TDPs................... 15

Figure 11. Frequency of run $>1 \mathrm{H}$ hours (hours per reactor year) trend for standby TDPs................... 16

Figure 12. Frequency of FTS events (events per reactor year) trend for standby TDPs....................... 16

Figure 13. Frequency of $\mathrm{FTR} \leq 1 \mathrm{H}$ events (events per reactor year) trend for standby TDPs. ................ 17

Figure 14. Frequency of FTR $>1 \mathrm{H}$ events (events per reactor year) trend for standby TDPs. ................ 17

Figure 15. Frequency of start demands (demands per reactor year) trend for normally running TDPs.

Figure 16. Frequency of run hours (hours per reactor year) trend for normally running TDPs.............. 19

Figure 17. Frequency of FTS events (events per reactor year) trend for normally running TDPs........... 20

Figure 18. Frequency of FTR events (events per reactor year) trend for normally running TDPs. .......... 20

Figure 19. TDP failure event breakdown by subcomponent, failure mode, and operational status. ......... 24

Figure 20. TDP failure event breakdown by cause group, failure mode, and operational status............. 25

Figure 21. TDP failure event breakdown by failure detection method, failure mode, and operational status.

Figure 22. TDP failure event breakdown by recoverability determination, failure mode, and operational status. 


\section{TABLES}

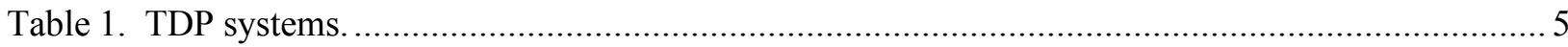

Table 2. Industry-wide distributions of $\mathrm{p}$ (failure probability) and $\lambda$ (hourly rate) for TDPs................... 5

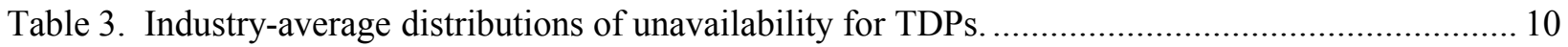

Table 4. Summary of TDP failure counts for the FTS failure mode over time by system. .................... 18

Table 5. Summary of TDP failure counts for the FTR $\leq 1 \mathrm{H}$ failure mode over time by system. .............. 18

Table 6. Summary of TDP failure counts for the FTR $>1 \mathrm{H}$ and FTR failure mode over time by

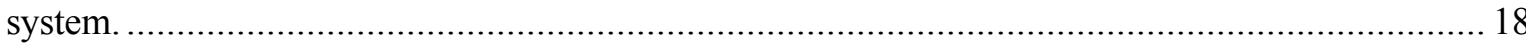

Table 7. Standby TDP unplanned demand performance comparison with industry-average performance.

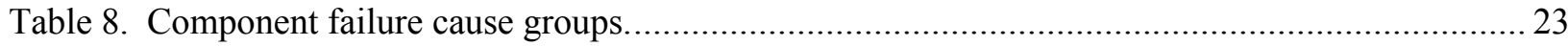

Table 9. Plot data for Figure 1, failure probability estimate trend for standby TDP FTS...................... 30

Table 10. Plot data for Figure 2, failure probability estimate trend for standby TDP FTR $\leq 1 \mathrm{H} . \ldots \ldots \ldots \ldots . . . .31$

Table 11. Plot data for Figure 3, failure rate estimate trend for standby TDP FTR $>1 \mathrm{H}$...................... 32

Table 12. Plot data for Figure 4, failure probability estimate trend for normally running TDP FTS.

Table 13. Plot data for Figure 5, failure rate estimate trend for normally running TDP FTR. 34

Table 14. Plot data for Figure 6, pooled standby TDP UA trend. 35

Table 15. Plot data for Figure 7, standby TDP unreliability trend (8-hour mission). 36

Table 16. Plot data for Figure 8, normally running TDP unreliability trend (8-hour mission). 37

Table 17. Plot data for Figure 9, frequency of start demands (demands per reactor year) trend for standby TDPs.

Table 18. Plot data for Figure 10, frequency of run $\leq 1 \mathrm{H}$ hours (hours per reactor year) trend for standby TDPs.

Table 19. Plot data for Figure 11, frequency of run $>1 \mathrm{H}$ hours (hours per reactor year) trend for standby TDPs.

Table 20. Plot data for Figure 12, frequency of FTS events (events per reactor year) trend for standby TDPs.

Table 21. Plot data for Figure 13, frequency of FTR $\leq 1 \mathrm{H}$ events (events per reactor year) trend for standby TDPs. 
Table 22. Plot data for Figure 14, frequency of FTR $>1 \mathrm{H}$ events (events per reactor year) trend for standby TDPs.

Table 23. Plot data for Figure 15, frequency of start demands (demands per reactor year) trend for normally running TDPs.

Table 24. Plot data for Figure 16, frequency of run hours (hours per reactor year) trend for normally running TDPs.

Table 25. Plot data for Figure 17, frequency of FTS events (events per reactor year) trend for normally running TDPs.

Table 26. Plot data for Figure 18, frequency of FTR events (events per reactor year) trend for normally running TDPs. 


\section{ACRONYMS}

\begin{tabular}{|c|c|}
\hline $\begin{array}{l}\text { AFW } \\
\text { AOV }\end{array}$ & $\begin{array}{l}\text { auxiliary feed water } \\
\text { air-operated valve }\end{array}$ \\
\hline $\begin{array}{l}\text { CNID } \\
\text { CY }\end{array}$ & $\begin{array}{l}\text { constrained non-informative prior distribution } \\
\text { calendar year }\end{array}$ \\
\hline $\begin{array}{l}\text { EDG } \\
\text { EPIX } \\
\text { EPS } \\
\text { ESF }\end{array}$ & $\begin{array}{l}\text { emergency diesel generator } \\
\text { Equipment Performance and Information Exchange } \\
\text { emergency power supply } \\
\text { engineered safety feature }\end{array}$ \\
\hline $\begin{array}{l}\text { FTR } \leq 1 \mathrm{H} \\
\text { FTR }>1 \mathrm{H} \\
\text { FTR } \\
\text { FTS } \\
\text { FY }\end{array}$ & $\begin{array}{l}\text { failure to run less than or equal to one hour } \\
\text { failure to run greater than one hour } \\
\text { failure to run } \\
\text { failure to start } \\
\text { fiscal year }\end{array}$ \\
\hline $\begin{array}{l}\text { HPCI } \\
\text { HPCS }\end{array}$ & $\begin{array}{l}\text { high-pressure coolant injection } \\
\text { high-pressure core spray }\end{array}$ \\
\hline $\begin{array}{l}\text { ICES } \\
\text { INL } \\
\text { INPO } \\
\text { IRIS }\end{array}$ & $\begin{array}{l}\text { INPO Consolidated Events Database } \\
\text { Idaho National Laboratory } \\
\text { Institute of Nuclear Power Operations } \\
\text { Industry Reporting and Information System }\end{array}$ \\
\hline $\begin{array}{l}\text { MDP } \\
\text { MFW } \\
\text { MOV } \\
\text { MSPI }\end{array}$ & $\begin{array}{l}\text { motor-driven pump } \\
\text { main feed water } \\
\text { motor-operated valve } \\
\text { Mitigating Systems Performance Index }\end{array}$ \\
\hline NPRDS & Nuclear Plant Reliability Data System \\
\hline OLS & ordinary least squares \\
\hline PRA & probabilistic risk assessment \\
\hline $\mathrm{RCIC}$ & reactor core isolation cooling \\
\hline TDP & turbine-driven pump \\
\hline UA & unavailability \\
\hline
\end{tabular}




\section{Enhanced Component Performance Study: Turbine-Driven Pumps 1998-2018}

\section{INTRODUCTION}

This report presents an enhanced performance evaluation of turbine-driven pumps (TDPs) at U.S. commercial nuclear power plants from 1998 through 2018. The objective of each updated component performance study is to obtain annual performance trends of failure rates and probabilities and to present an analysis of factors that could influence the component trends. This year's update continues with the two changes implemented in the 2016 update that are different from earlier updates: (1) the update results are based on calendar year (CY) instead of the federal fiscal year (FY), and (2) The failure events included in the update are "hard" failures, i.e., the p-values indicating the likelihood the component would have failed during a 24-hour mission are 1.0. Previous updates (2015 and before) include lesser p-values indicating a degraded condition that probably would have caused failure during a 24-hour mission but were not quite hard failures at their outset.

The enhanced component performance studies are conducted for the following component types: airoperated valves (AOVs), emergency diesel generators (EDGs), motor-driven pumps (MDPs), motoroperated valves (MOVs), and TDPs. The TDP performance analysis was originally published as NUREG1715, Volume 1 in April 2000 [1] and then updated annually in a series of reports, with the last one being documented in INL/EXT-17-441163, Enhanced Component Performance Study: Turbine-Driven Pumps 1998-2016 [2]. The Nuclear Regulatory Commission (NRC) Reactor Operational Experience Results and Databases web page provides the links to the historical and current results of component performance studies (http://nrcoe.inl.gov/resultsdb/CompPerf). An overview of the trending methods, glossary of terms, and abbreviations is documented in the paper Overview and Reference [3] that can also be found on that web page.

The data used in this study are based on the operating experience failure reports from Institute of Nuclear Power Operations (INPO) Consolidated Events Database (ICES) [4], formerly the Equipment Performance and Information Exchange Database (EPIX) and now upgraded again to IRIS, the Industry Reporting and Information System. Maintenance unavailability (UA) performance data came from the Reactor Oversight Process program's Mitigating Systems Performance Index (MSPI) program [5] and ICES. Previously, the study relied on operating experience obtained from licensee event reports, Nuclear Plant Reliability Data System (NPRDS), and ICES. The ICES database, now IRIS, (which includes the MSPI designated devices as a subset) has matured to the point where both component availability and reliability can be estimated with a high degree of accuracy. In addition, the population of data in current ICES database is much larger than the population available in the previous study.

TDPs are categorized as either standby or normally running. The TDP failure modes considered for standby systems are: failure to start (FTS), failure to run less than or equal to one hour $(\mathrm{FTR} \leq 1 \mathrm{H})$, and failure to run greater than one hour $(\mathrm{FTR}>1 \mathrm{H})$. The TDP failure modes considered for normally running systems are: FTS and failure-to-run (FTR). Annual failure probabilities (failures per demand) are provided for FTS and FTR $\leq 1 \mathrm{H}$ events. Annual failure rates (failures per run hour) are provided for FTR $>$ $1 \mathrm{H}$ and FTR events. TDP train maintenance unavailability probabilities are also considered. In addition to the presentation of the component failure mode data and the UA data, an 8-hour total unreliability is calculated and trended. Each of the estimates is trended for the most recent 10-year period while yearly estimates are provided for the entire study period.

While this report provides an overview of operational data and evaluates component performance over time, it makes no attempt to estimate values for use in probabilistic risk assessments (PRAs). The 
2015 Component Reliability Update [6], is an update to NUREG/CR-6928, Industry-Average

Performance for Components and Initiating Events at U.S Commercial Nuclear Power Plants [7], and reports the TDP unreliability estimates for probabilistic risk assessments. Estimates from that report are included herein, for comparison. Those estimates are labelled "2015 Update" (or "Update 2015") in the associated tables and figures.

Section 2 of this report presents the summary of findings from the study, with particular interest in the existence of any statistically significant increasing or decreasing trends in component performances. Section 3 provides annual estimates of failure probabilities and rates related to TDPs as well as the trending of the estimates. Section 4 provides TDP train UA estimates and their trends. Section 5 estimates the annual total unreliability and the trends for TDP. Section 6 presents various engineering analyses performed for TDP such as the trend for demands/run hours per plant reactor year, the trend for failures per plant reactor year, and the breakdown of TDP failures by sub-components, failure causes, detection methods, and recovery possibility, etc. A comparison of ICES TDP unplanned demand results with the 2015 Update industry-average results for standby TDPs is also conducted in Section 6 in order to determine whether the current data are consistent with the estimated values used in PRA. Section 7 provides the TDP assembly information. Section 8 presents the plot data for various figures in previous sections. 


\section{SUMMARY OF FINDINGS}

The results of this study are summarized in this section. Of particular interest is the existence of any statistically significant ${ }^{\mathrm{a}}$ increasing trends.

\subsection{Increasing Trends}

\subsubsection{Extremely Statistically Significant}

- None.

\subsubsection{Highly Statistically Significant}

- None.

\subsubsection{Statistically Significant}

- None.

\subsection{Decreasing Trends}

\subsubsection{Extremely Statistically Significant}

- None.

\subsubsection{Highly Statistically Significant}

- A highly statistically significant decreasing trend in the standby TDP unavailability estimates was identified with a p-value of 0.0058 (see Figure 6). This is a new trend that was not observed in the 2016 TDP update study [2].

\subsubsection{Statistically Significant}

- None.

\subsection{Consistency Check Results}

An ongoing concern in the industry is whether industry average failure estimates adequately predict standby component performance during unplanned (ESF) demands. Section 6.3 provides the results of a consistency check that compare failure predictions obtained via simulation test on industry-average parameters from the 2015 Update against operational failure counts obtained from actual TDP performance with ESF demands. These consistency checks show that the FTS and FTR $>1 \mathrm{H}$ failure observations in the non-test, operational ESF demand data lie within their corresponding industry-average failure estimate distributions, provided in the 2015 Update (Table 2), that were based on both test and non-test operational ESF demands. However, the FTR $\leq 1 \mathrm{H}$ failure observations are not consistent with the

a. Statistically significant is defined in terms of the 'p-value.' A p-value is a probability indicating whether to accept or reject the null hypothesis that there is no trend in the data. P-values of less than or equal to 0.05 indicate that we are $95 \%$ confident that there is a trend in the data (reject the null hypothesis of no trend.) By convention, we use the "Michelin Guide" scale: p-value $<0.05$ (statistically significant), p-value $<0.01$ (highly statistically significant); p-value $<0.001$ (extremely statistically significant). 
industry-average failure estimate distributions, which means that the TDP performs worse on a non-test, operational ESF demand than on a test demand. 


\section{FAILURE PROBABILITIES AND FAILURE RATES}

\subsection{Overview}

TDPs are categorized as either standby or normally running. The industry-wide failure probabilities and failure rates have been calculated from the operating experience for standby pump FTS, FTR $\leq 1 \mathrm{H}$, and FTR $>1 \mathrm{H}$, and for normally running pumps FTS and FTR. The TDP data set obtained from ICES includes TDPs in the systems listed in Table 1. This report follows the definition of these categories in NUREG/CR-6823 [8], which determines the status by evaluating the number of run-hours per demand. The pumps with low run-hours per demand $(\leq 360)$ are considered standby while those with higher runhours per demand $(>360)$ are considered normally running.

Table 2 shows industry-wide failure probability and failure rate results for the TDP from Reference [6], or the 2015 Update. The 2015 Update results are provided for comparison purposes and are important because they are intended for use in PRA. The results in this section demonstrate the extent to which the 2015 Update results remain suitable estimates for use in PRA.

The TDPs are assumed to operate both when the reactor is critical and during shutdown periods with sufficient steam pressure. The number of TDPs in operation is the number that have been in operation at some time during the study period. So new devices put in service during the period are included, as are devices that were in service at one time but have since been removed from service. All demand types are considered - testing, non-testing, and, as applicable, ESF demands.

Table 1. TDP systems.

\begin{tabular}{llccc}
\hline System & \multicolumn{1}{c}{ Description } & Total & Normally Running & Standby \\
\hline AFW & Auxiliary feed water & 74 & & 74 \\
HPCl & High pressure coolant injection & 28 & & 28 \\
MFW & Main feed water & 43 & 43 & \\
RCIC & Reactor core isolation cooling & 31 & & 31 \\
& Total & 176 & 43 & 133 \\
\hline
\end{tabular}

Table 2. 2015 Update industry-wide distributions of $p$ (failure probability) and $\lambda$ (hourly rate) for TDPs.

\begin{tabular}{|c|c|c|c|c|c|c|c|c|}
\hline \multirow[b]{2}{*}{ Operation } & \multirow{2}{*}{$\begin{array}{c}\text { Failure } \\
\text { Mode }\end{array}$} & \multirow[b]{2}{*}{$5 \%$} & \multirow[b]{2}{*}{ Median } & \multirow[b]{2}{*}{ Mean } & \multirow[b]{2}{*}{$95 \%$} & \multicolumn{3}{|c|}{ Distribution } \\
\hline & & & & & & Type & $\alpha$ & $\beta$ \\
\hline \multirow[t]{3}{*}{ Standby } & FTS & $5.35 \mathrm{E}-4$ & $4.51 \mathrm{E}-3$ & $5.93 \mathrm{E}-3$ & $1.62 \mathrm{E}-2$ & Beta & 1.29 & $2.16 \mathrm{E}+02$ \\
\hline & $\mathrm{FTR} \leq 1 \mathrm{H}$ & $1.51 \mathrm{E}-4$ & $2.48 \mathrm{E}-3$ & $3.71 \mathrm{E}-3$ & $1.15 \mathrm{E}-2$ & Gamma & 0.91 & $2.46 \mathrm{E}+02$ \\
\hline & $\mathrm{FTR}>1 \mathrm{H}$ & $1.51 \mathrm{E}-3$ & 2.17E-3 & $2.20 \mathrm{E}-3$ & $2.99 \mathrm{E}-3$ & Gamma & 23.50 & $1.07 E+04$ \\
\hline \multirow{2}{*}{$\begin{array}{l}\text { Running/ } \\
\text { Alternating }\end{array}$} & FTS & $4.01 \mathrm{E}-4$ & $6.20 \mathrm{E}-3$ & $9.16 \mathrm{E}-3$ & $2.78 \mathrm{E}-2$ & Beta & 0.94 & $1.02 E+02$ \\
\hline & FTR & $1.52 \mathrm{E}-6$ & $8.68 \mathrm{E}-6$ & $1.07 \mathrm{E}-5$ & $2.67 \mathrm{E}-5$ & Gamma & 1.70 & $1.59 \mathrm{E}+05$ \\
\hline
\end{tabular}

\subsection{TDP Failure Probability and Failure Rate Trends}

This section estimates industry-wide annual failure probabilities and failure rates for standby and normally running TDPs in the entire study period which covers 1998 through 2018 . The estimates are trended for the most recent 10-year period.

The failure probability and failure rate estimates in this section were obtained from a Bayesian update process. The means from the posterior distributions were plotted for each year. The 5 th and 95 th 
percentiles from the posterior distributions are also provided and give an indication of the relative uncertainty in the estimated parameters from year to year. When there are no failures, the interval is larger than the interval for years when there are one or more failures because of the form of the posterior variance. Each update utilizes a relatively "flat" constrained non-informative prior distribution (CNID), which has wide bounds [3, 8]. CNID is a compromise between an informative prior and the Jeffreys noninformative prior. The mean of the CNID uses prior belief and is based on a pooling of the component or event type data for the years going into the plot (i.e., the most recent 10-year period), but the dispersion is defined to correspond to little information (i.e., relatively flat by set) so that the prior distributions did not create large changes in the data.

For failure rates or Poisson data, the CNID is a gamma distribution, with the mean $(\mu)$ given by prior belief and calculated as:

$$
\mu=\frac{\sum f_{i}+0.5}{\sum T_{i}}
$$

where $f_{i}$ and $T_{i}$ are the failures and operating/standby time for the $\mathrm{i}^{\text {th }}$ year, respectively. The CNID shape parameter $=0.5$. The posterior distribution mean for the $\mathrm{i}^{\text {th }}$ year $\left(\mu_{i}\right)$ can be calculated as:

$$
\mu_{i}=\frac{f_{i}+0.5}{\frac{0.5}{\mu}+T_{i}}
$$

For failure probabilities or binomial data, the CNID is a beta approximation, with the mean given by prior belief and calculated as:

$$
\mu=\frac{\sum f_{i}+0.5}{\sum D_{i}+1}
$$

where $f_{i}$ and $D_{i}$ are the failures and demands for the $\mathrm{i}^{\text {th }}$ year, respectively. The CNID shape parameter $(\alpha)$ is a number between 0.3 and 0.5 based on the mean $\mu$ (see Table C.8 of [8]). The posterior distribution mean for the $\mathrm{i}^{\text {th }}$ year $\left(\mu_{i}\right)$ can be calculated as:

$$
\mu_{i}=\frac{f_{i}+\alpha}{\frac{\alpha}{\mu}+D_{i}}
$$

The horizontal curves plotted around the regression lines in the graphs form $90 \%$ simultaneous confidence bands for the fitted lines. The bounds are larger than ordinary confidence bands for the individual coefficients because they form a confidence band for the entire line. In the lower left hand corner of the trend figures, the regression p-values are reported. They come from a statistical test to assess evidence against the slope of the regression line being zero. Low $p$-values indicate strong evidence that the slopes are not zero, and suggest a trend does exist. P-values of less than or equal to 0.05 indicate that we are $95 \%$ confident that there is a trend in the data (reject the null hypothesis of no trend.) By convention, this study uses the "Michelin Guide" scale: p-value $<0.05$ (statistically significant), p-value $<$ 0.01 (highly statistically significant); $p$-value $<0.001$ (extremely statistically significant).

The regression methods are all based on "ordinary least squares" (OLS), which minimizes the residuals, or the square of the vertical distance between the annual data points and the fitted regression line. The p-values assume normal distributions for the residuals, with the same variability in the residuals across the years. In the case where the data involve failure counts, the iterative reweighted least squares is used to account for the fact that count data are not expected to have a constant variance (for example, the variance for Poisson-distributed counts is equal to the expected number of counts, which is expected to vary proportionally to the expected number of counts). Further information on the trending methods is provided in Section 2 of the Overview and Reference document [3]. 
A final feature of the trend graphs is that the 2015 Update baseline industry values from Table 2 are shown for comparison.

Figure 1 to Figure 5 provide the plots for industry-wide failure probabilities/rates of standby and normally running TDPs. The data for these plots are provided in Section 8.

- Figure 1 shows the failure probability estimate trends for standby TDP FTS.

- Figure 2 shows the failure probability estimate trends for standby TDP FTR $\leq 1 \mathrm{H}$.

- Figure 3 shows the failure rate estimate trends for standby TDP FTR $>1 \mathrm{H}$.

- Figure 4 shows the failure probability estimate trends for normally running TDP FTS.

- Figure 5 shows the failure rate estimate trends for normally running TDP FTR.

No trends were identified for TDP failure probabilities/rates for FTS, FTR $\leq 1 \mathrm{H}, \mathrm{FTR}>1 \mathrm{H}$, and FTR events in the most recent 10 -year period.

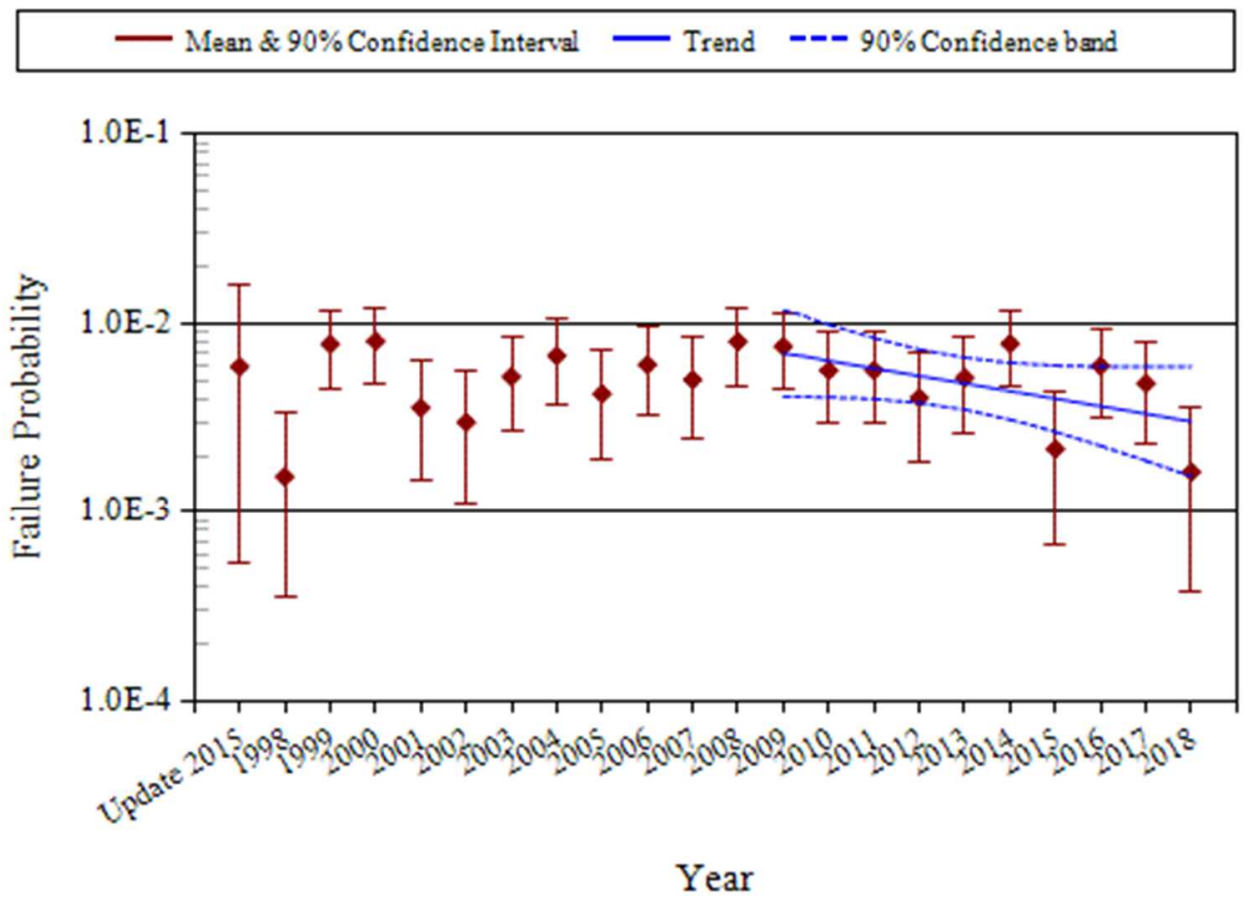

CNID, $p$-value $=0.0746$

All Standby TDP FTS $9 / 12 / 2019$

Figure 1. Failure probability estimate trend for standby TDP FTS. 


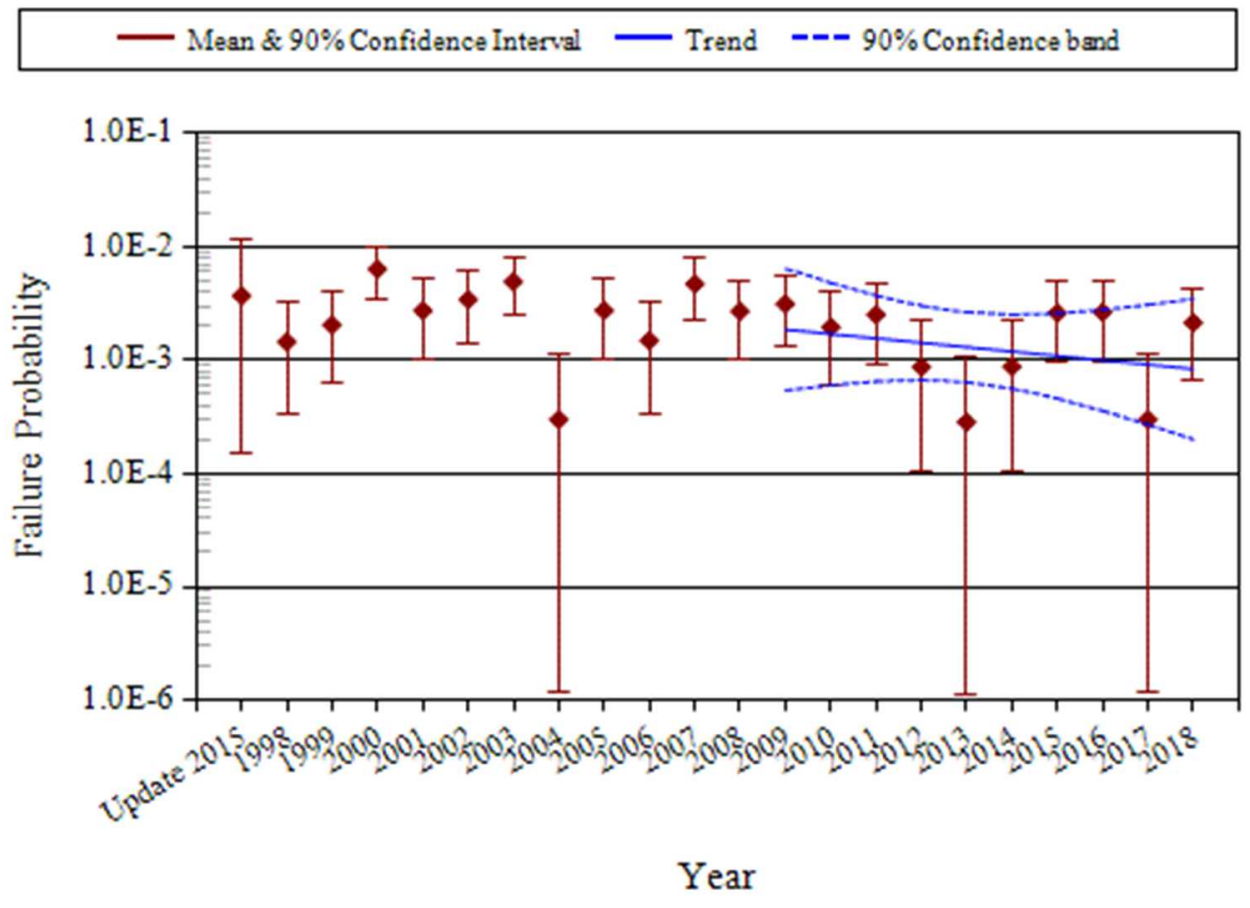

CNID, $p$-value $=0.3995$

All Standby TDP FTRlt1 H 9/12/2019

Figure 2. Failure probability estimate trend for standby TDP FTR $\leq 1 H$.
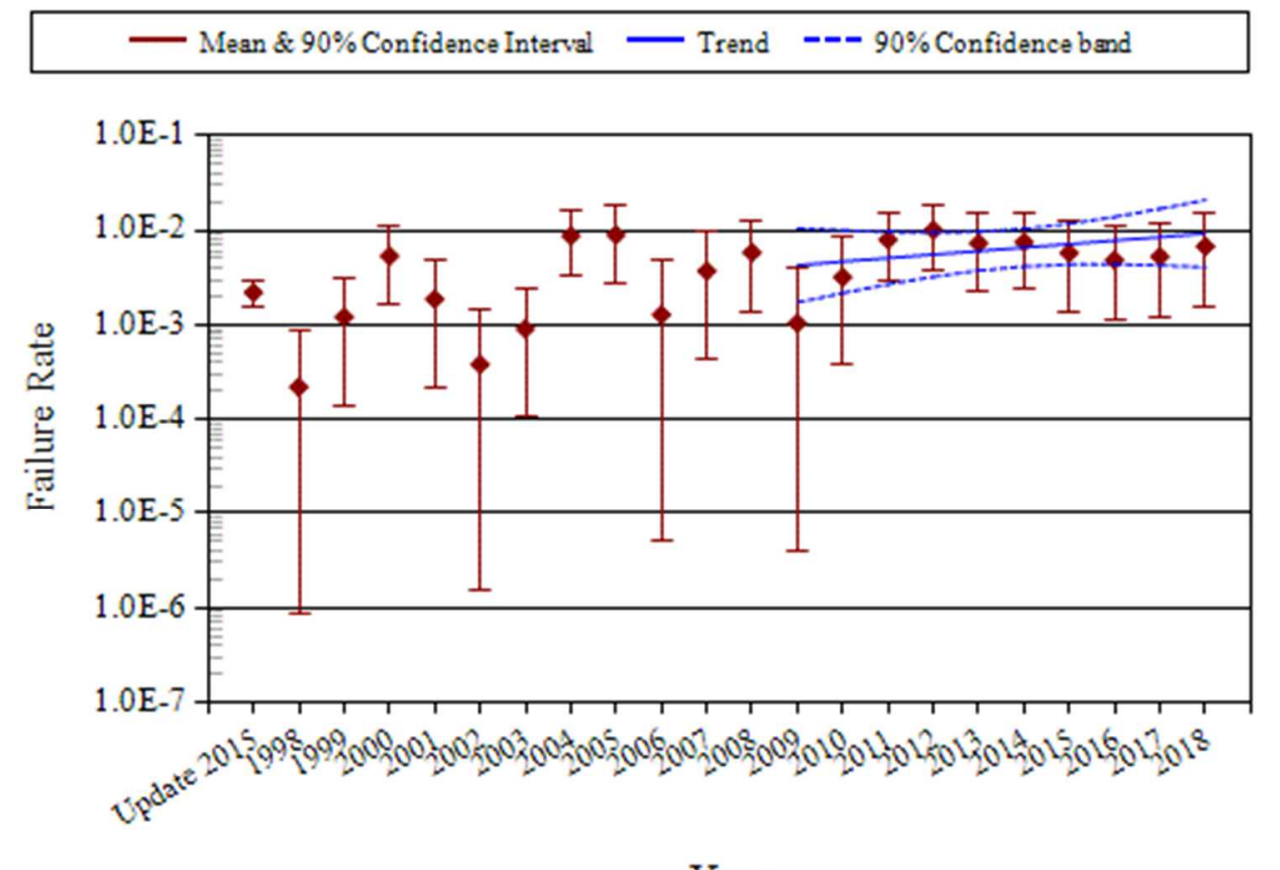

Year

CNID, $p$-value $=0.2236$

All Standby TDP FTRgtlH 9/12/2019

Figure 3. Failure rate estimate trend for standby TDP FTR $>1 \mathrm{H}$. 


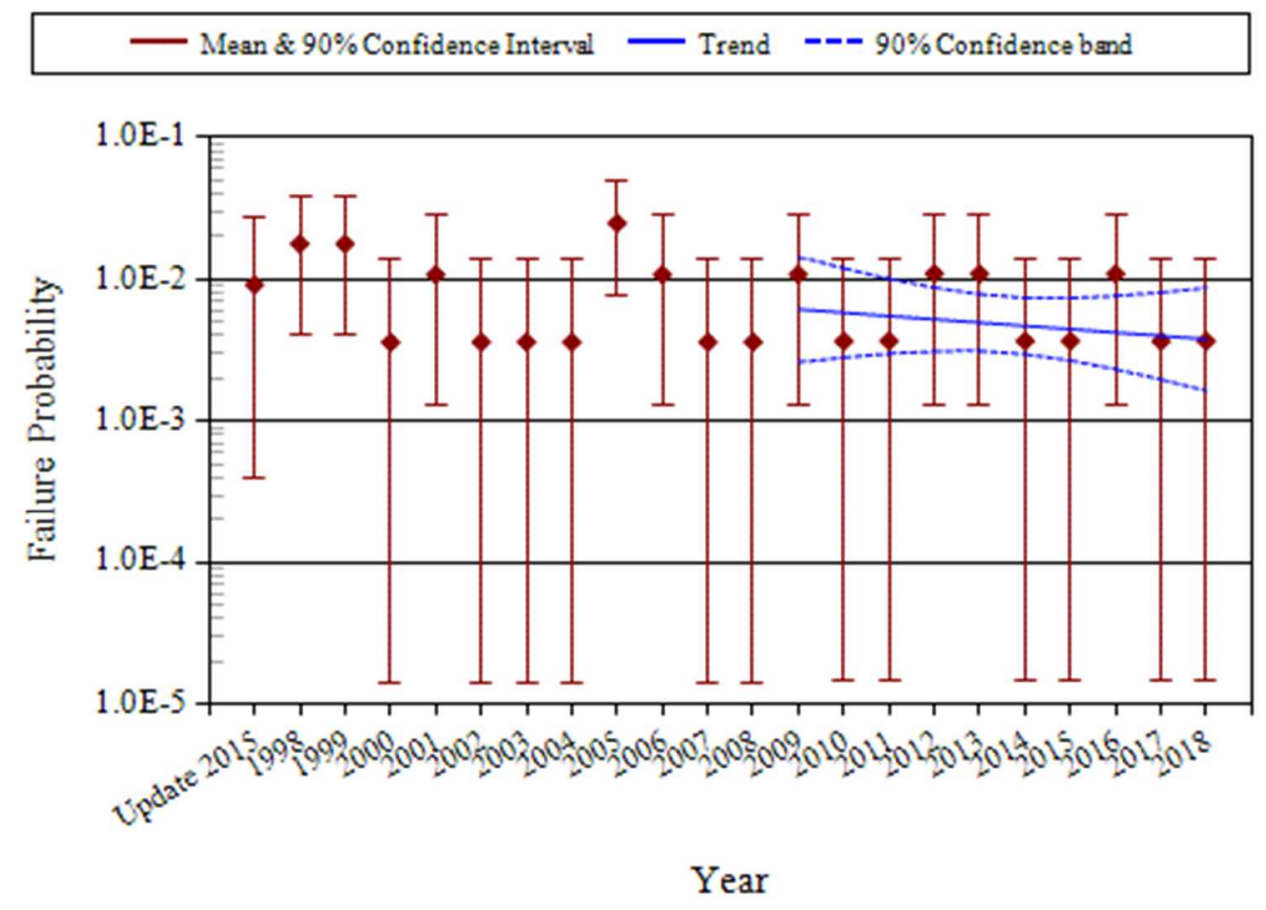

CNID, $p$-value $=0.4223$

All Normally Running TDP FTS $9 / 12 / 2019$

Figure 4. Failure probability estimate trend for normally running TDP FTS.

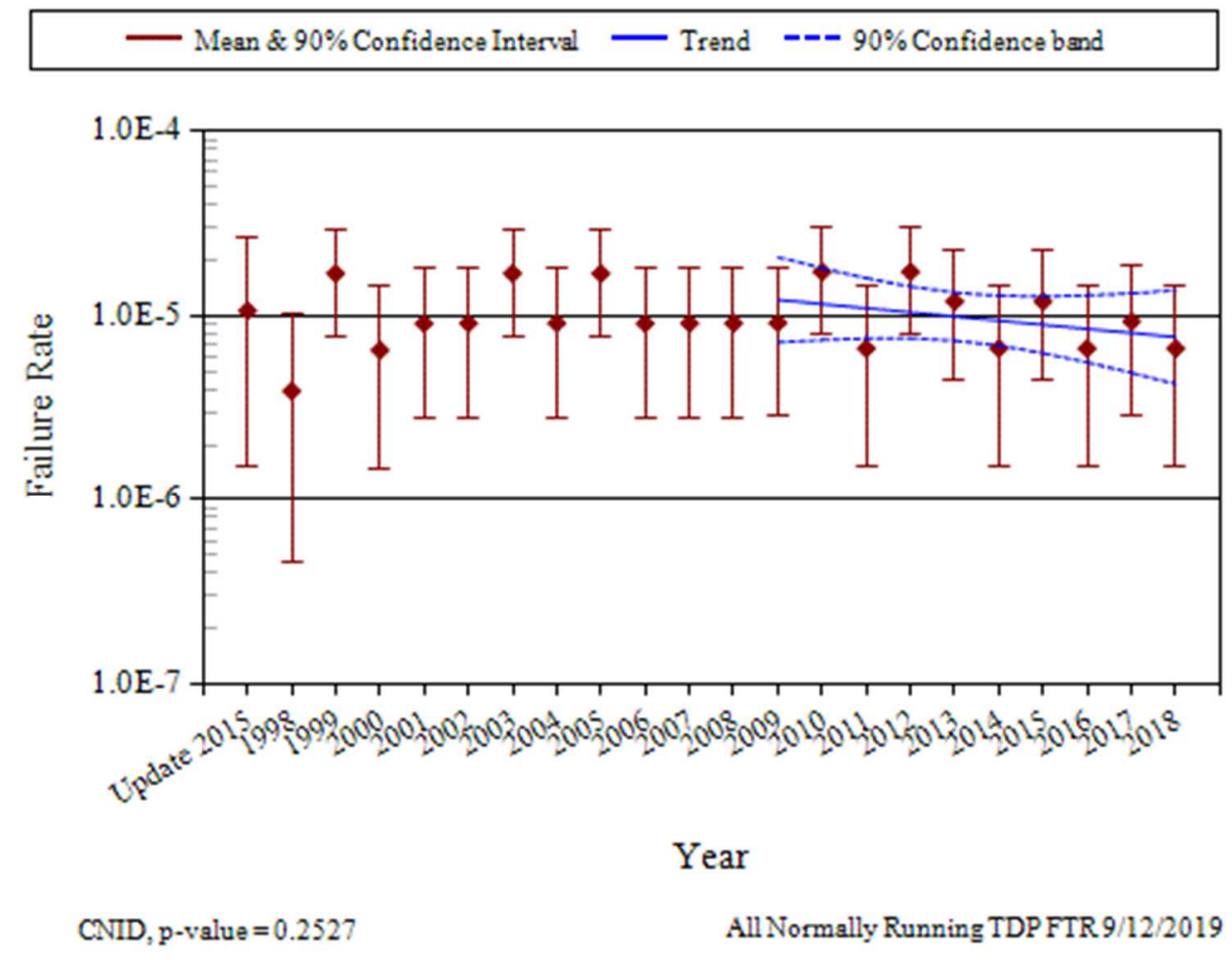

Figure 5. Failure rate estimate trend for normally running TDP FTR. 


\section{UNAVAILABILITY}

\subsection{Overview}

The industry-wide test or maintenance UA of TDP trains has been calculated from operating experience. UA data are for TDP trains, which can include more than just the TDP. However, in most cases the TDP contributes the majority of the UA reported. Table 3 shows overall results for the TDP from the 2015 Update [6] which based on UA data from the MSPI program and ICES. In the calculations, planned and unplanned unavailable hours for a train are combined.

Table 3. 2015 Update industry-average distributions of unavailability for TDPs.

\begin{tabular}{lcccc}
\hline \multicolumn{1}{c}{ Description } & Distribution & Mean & $\boldsymbol{\alpha}$ & $\boldsymbol{\beta}$ \\
\hline TDP Test or Maintenance (AFW) & Normal & $5.24 \mathrm{E}-3$ & 0.0052 & 0.0030 \\
TDP Test or Maintenance (HPCI) & Normal & $1.17 \mathrm{E}-2$ & 0.0117 & 0.0027 \\
TDP Test or Maintenance (RCIC) & Normal & $1.04 \mathrm{E}-2$ & 0.0104 & 0.0046 \\
TDP Test or Maintenance (All) & Normal & $7.25 \mathrm{E}-3$ & 0.0072 & 0.0042 \\
\hline
\end{tabular}

\subsection{TDP Unavailability Trends}

This section presents overall maintenance UA data for the 1998-2018 period. Note that these data do not supersede the data in Table 3 for use in risk assessments.

The trend in standby TDP train unavailability is shown in Figure 6. The data for this figure is in Section 8. The TDPs in systems AFW, HPCI, and RCIC are pooled and trended (these are the systems with maintenance unavailability data currently analyzed). The trend chart shows the results of using data for each year's component unavailability data over time. The yearly (1998-2018) unavailability and reactor critical hour data were obtained from the Reactor Oversight Process program (1998 to 2001) and ICES (2002 to 2018) data for the TDP component. The total downtimes during operation for each plant and year were summed, and divided by the corresponding number of TDP-reactor critical hours. Unavailability data for shutdown periods are not reported.

The mean and variance for each year is the sample mean and variance calculated from the plant-level unavailabilities for that year. The vertical bar spans the calculated 5th to 95th percentiles of the beta distribution with matching means.

For the trend graphs, a least squares fit is sought for the linear or logit model. Section 3 in the Overview and Reference document provides further information [3]. In the lower left hand corner of the trend figures, the $\mathrm{p}$-value is reported. A review of the $\mathrm{p}$-value identified the following trend for the most recent 10-year period:

0 Highly statistically significant decreasing trend in the standby TDP unavailability estimates, with a p-value of 0.0058 (see Figure 6). This is a new trend that was not observed in the 2016 TDP update study [2]. 


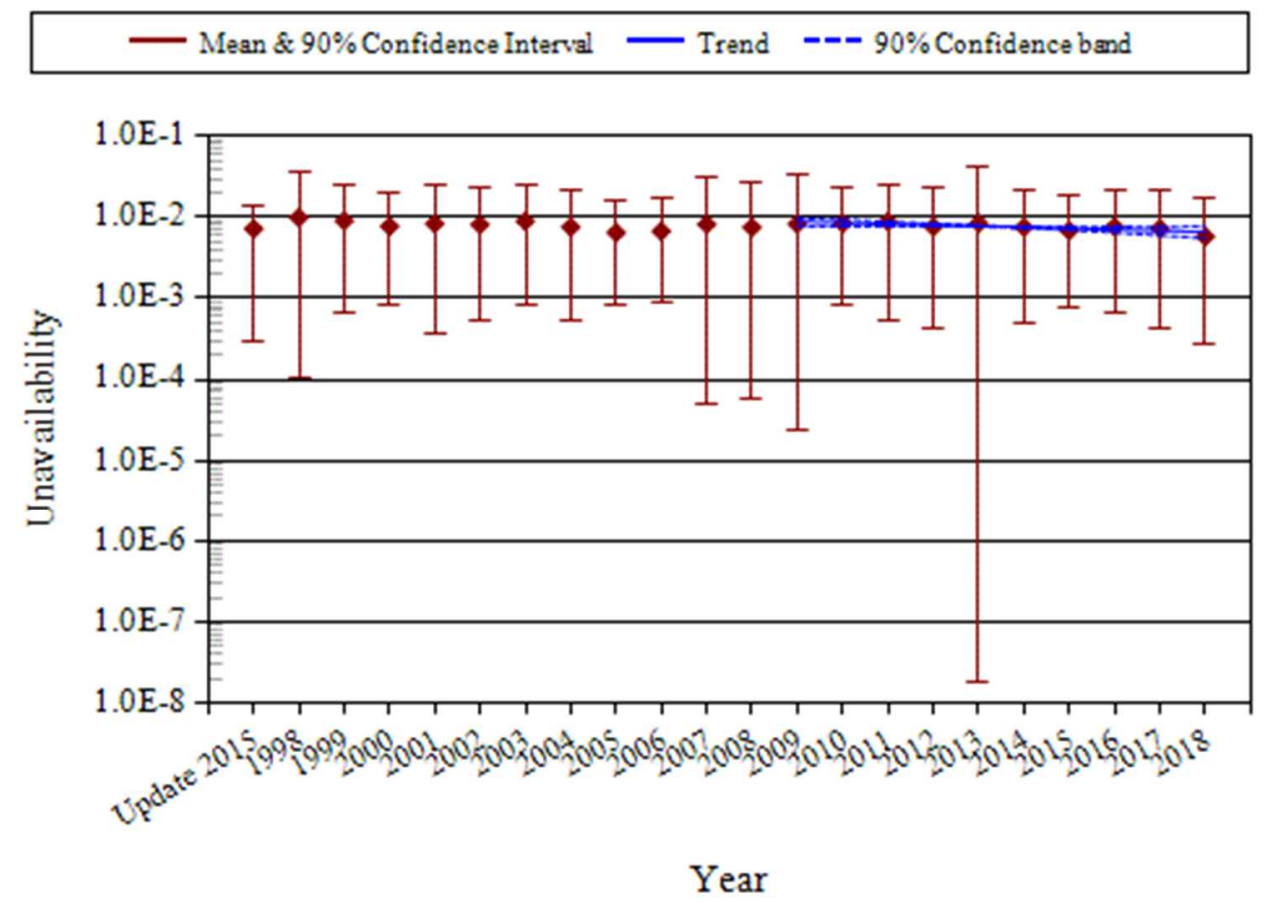

Linear, $p$-value $=0.0058$

All -- TDPUA 9/12/2019

Figure 6. Pooled standby TDP UA trend. 


\section{TDP UNRELIABILITY TRENDS}

Trends in total component unreliability are shown in Figure 7 and Figure 8. Plot data for these figures are in Section 8. Total unreliability is defined as the result of the union of the UA, FTS, FTR $\leq 1 \mathrm{H}$, and FTR $>1 \mathrm{H}$ (or FTR) failure probabilities. The FTR $>1 \mathrm{H}$ is calculated for 7 hours and the FTR is calculated for 8 hours to provide the results for an 8 -hour mission. Since the normally running systems TDP components do not have UA data or the FTR $\leq 1 \mathrm{H}$ data, there is no UA or FTR $\leq 1 \mathrm{H}$ for that calculation. The trending method is described in more detail in Section 4 of the Overview and Reference document [3]. In the lower left hand corner of the trend figures, the regression method is reported. There are no statistically significant trends identified in the TDP total unreliability estimates for the most recent 10 -year period.

There is no total unreliability estimates in the 2015 Update and so there is no 2015 Update baseline industry values shown in Figure 7 and Figure 8 for comparison purpose.

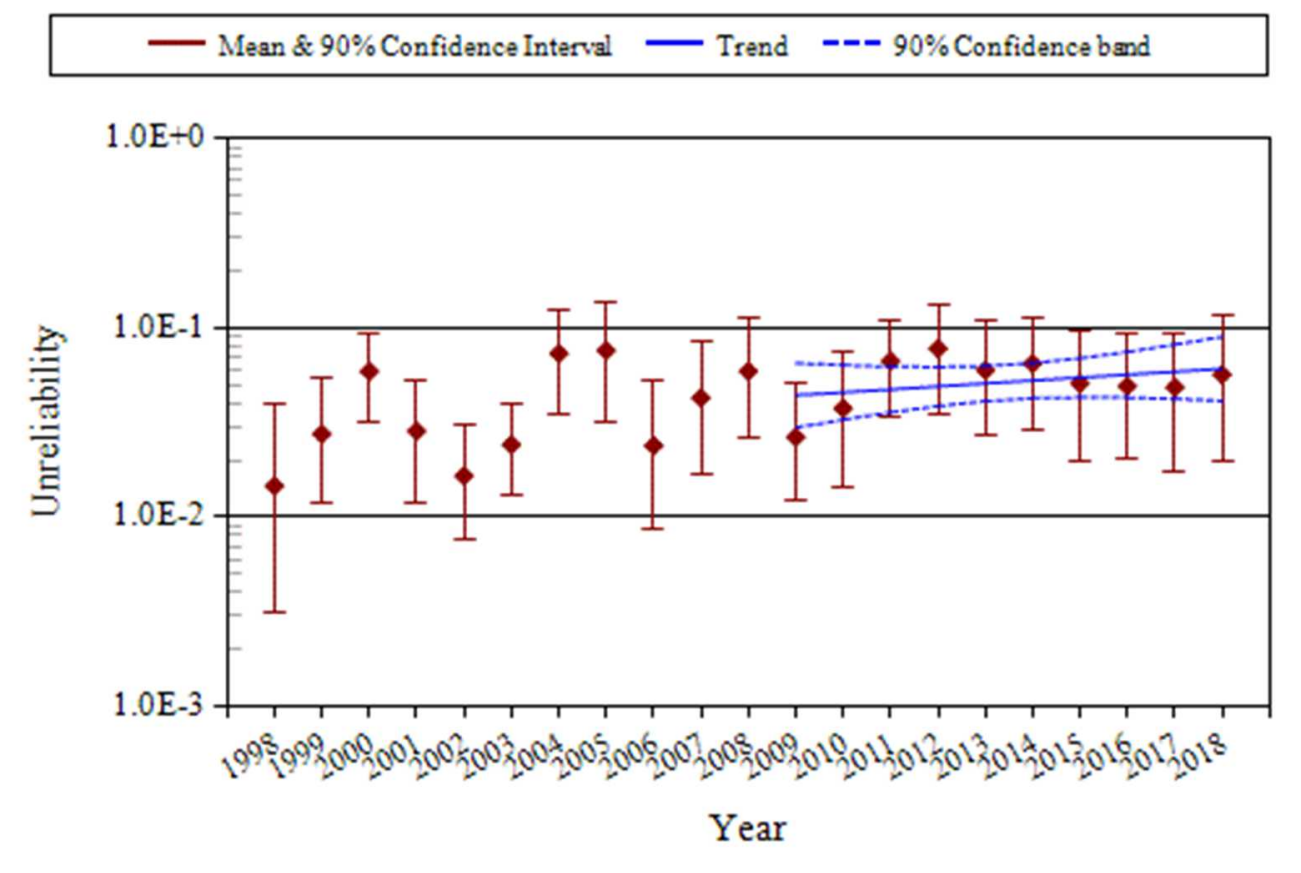

LogLinear, $p$-value $=0.3225$

All Standby TDP Total $9 / 12 / 2019$

Figure 7. Standby TDP unreliability trend (8-hour mission). 


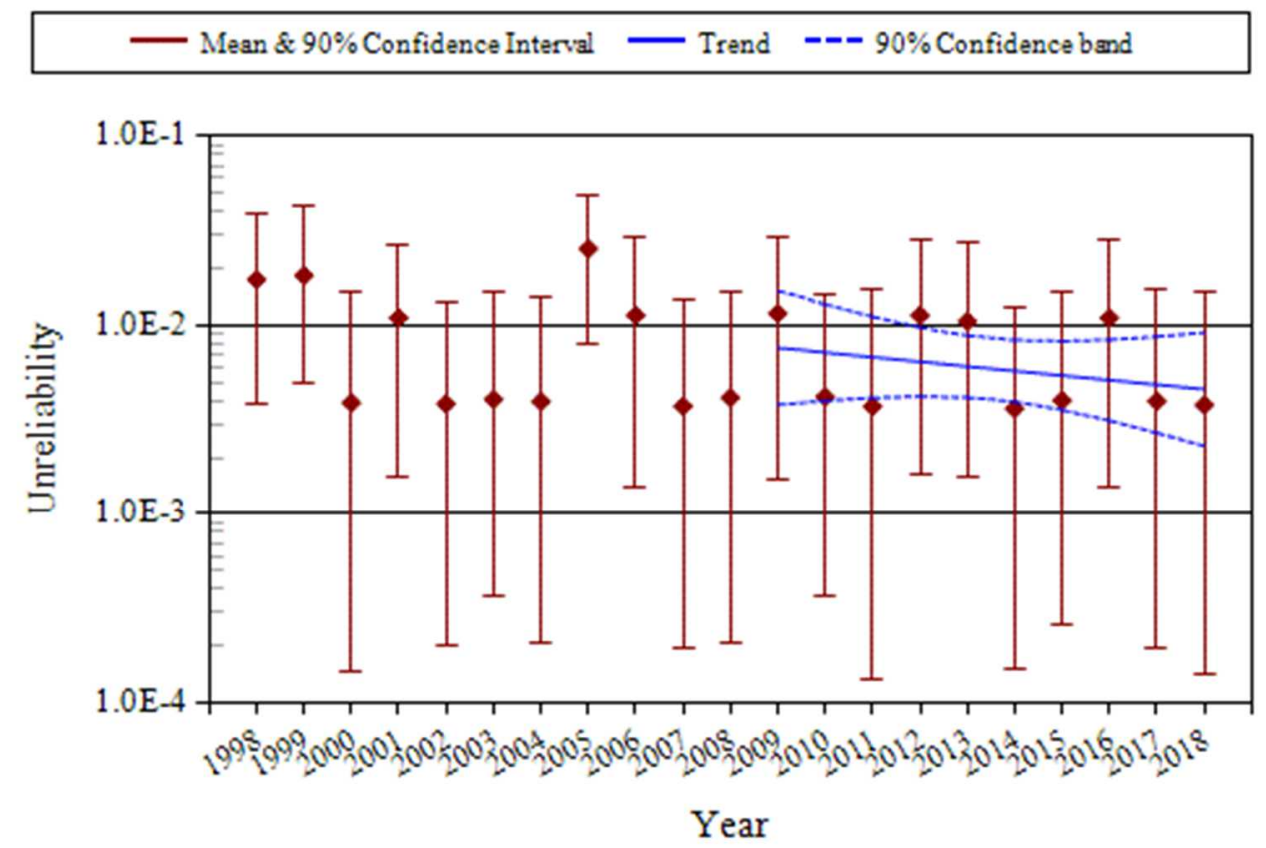

LogLinear, $p$-value $=0.3825$

All Normally Running TDP Total 9/12/2019

Figure 8. Normally running TDP unreliability trend (8-hour mission). 


\section{ENGINEERING ANALYSIS}

This section presents various engineering analyses performed for TDP. Frequency trends of component failures and demands are presented in Sections 6.1 and 6.2 for standby and normally running TDPs, respectively. The data are normalized by reactor year for plants that have the equipment being trended. A comparison of ICES TDP unplanned demand results with the industry-average results for standby TDPs is presented in Section 6.3 to determine whether the current data are consistent with the 2015 Update values used in PRA. An engineering analysis of TDP failure breakdown by failure mode and other factors is presented in Section 6.4. The factors analyzed are sub-components, failure causes, detection methods, and recovery possibility.

\subsection{Standby TDP Engineering Trends}

This section presents frequency trends for standby TDP failures and demands. The data are normalized by reactor year for plants that have the equipment being trended. The trends provide an overview of the demand counts and failure counts associated with each failure mode across the years.

- Figure 9 shows the trend for standby TDP frequency of start demands (demands per reactor year).

- Figure 10 shows the trend for standby TDP run hours per reactor year of run $\leq 1 \mathrm{H}$ hours.

- Figure 11 shows the trend for standby TDP run hours per reactor year.

- Figure 12 shows the trend for standby TDP frequency of FTS events (i.e., FTS events per reactor year).

- Figure 13 shows the trend for standby TDP FTR $\leq 1 \mathrm{H}$ events per reactor year.

- Figure 14 shows the trend for standby TDP FTR events per reactor year.

The data for the above figures are provided in Section 8 . The standby systems from Table 1 are trended together for each figure.

In the lower left hand corner of the above trend figure, the regression p-values are reported. A review of these p-values shows that there are no statistically significant trends existing in the standby TDP engineering trends for the most recent 10-year period.

Table 4 to Table 6 provide a summary of TDP (both standby and normally running) FTS, FTR $\leq 1 \mathrm{H}$, and FTR $>1 \mathrm{H}$ failure counts by system and year during the most recent 10 -year period.

- Table 4 presents the TDP FTS failure counts by system and year.

- Table 5 presents the TDP FTR $\leq 1 \mathrm{H}$ failure counts by system and year.

- Table 6 presents the TDP FTR $>1 \mathrm{H}$ failure counts by system and year. 


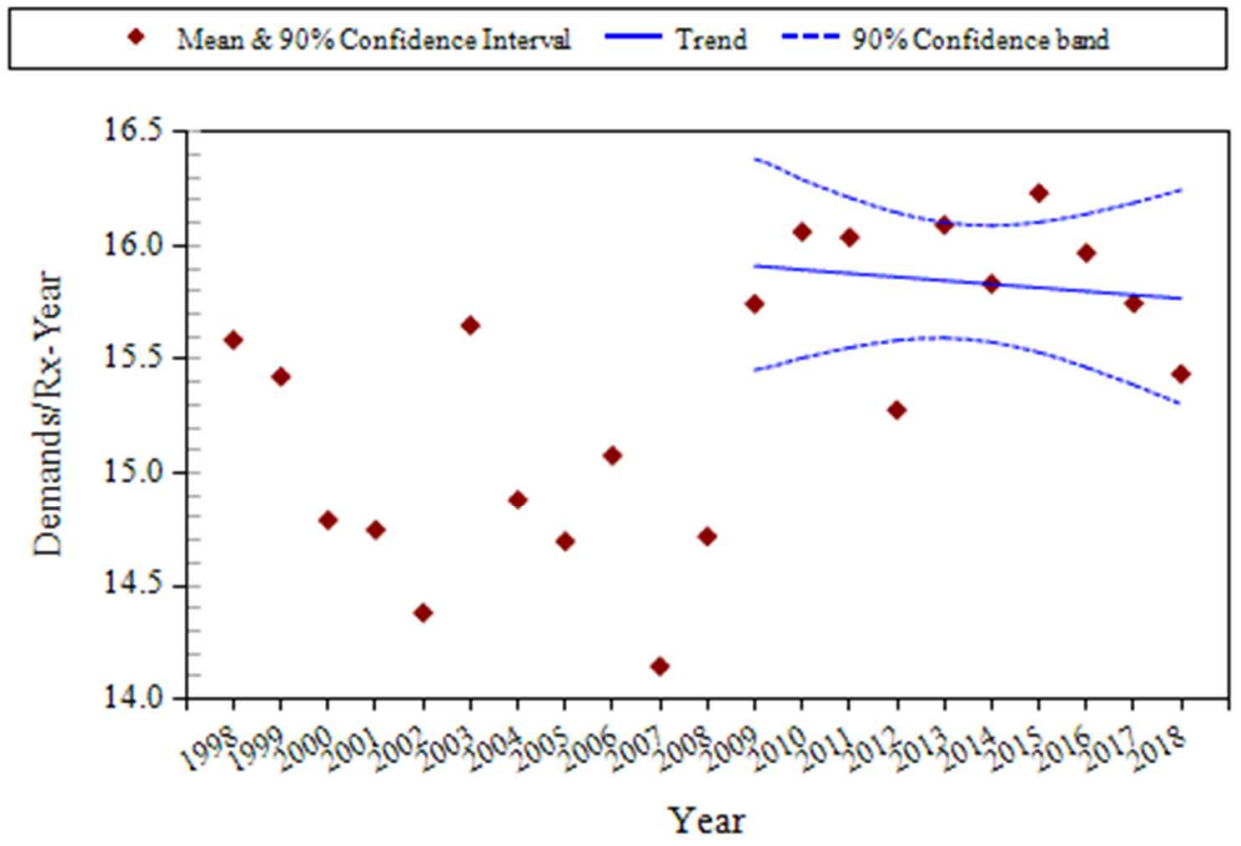

CNID, $p$-value $=0.6646$

All Standby TDP FTS $9 / 12 / 2019$

Figure 9. Frequency of start demands (demands per reactor year) for standby TDPs.
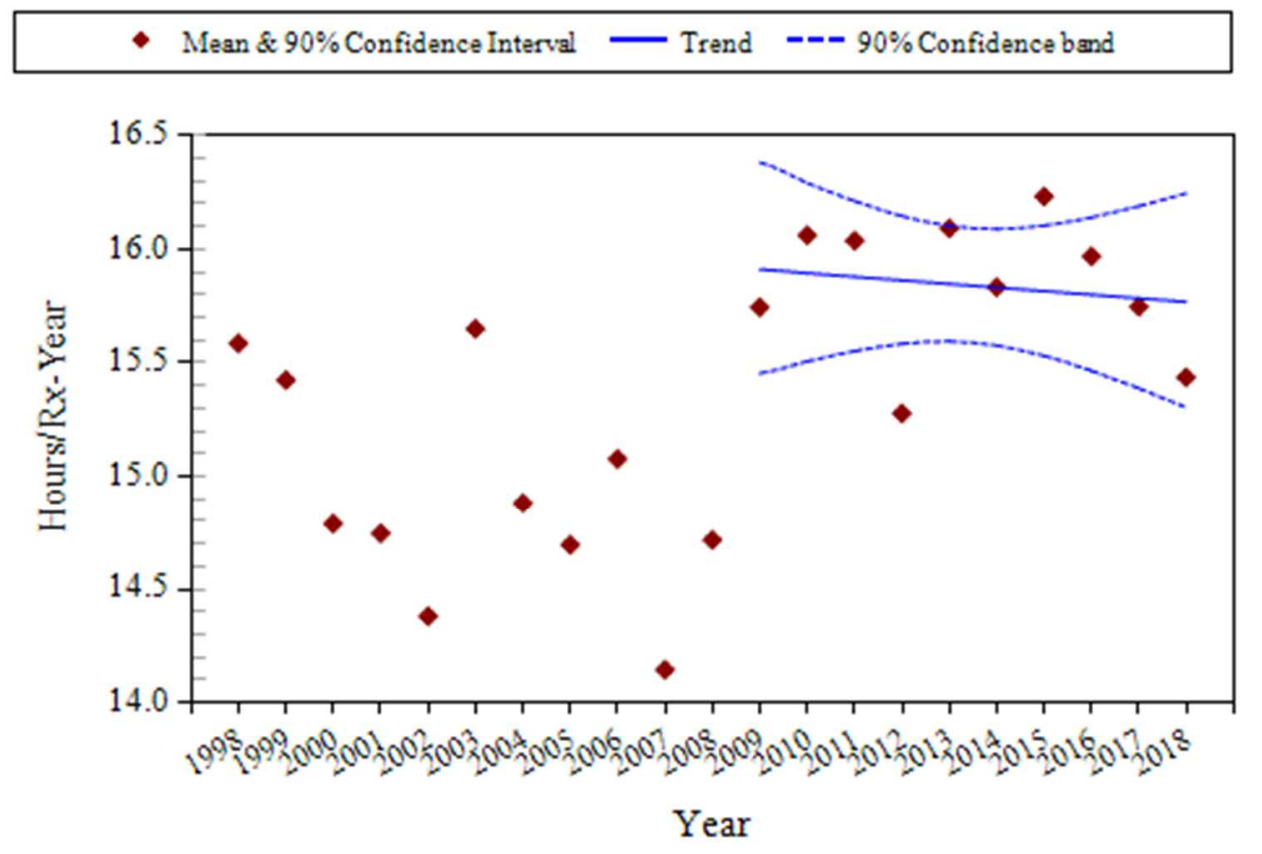

CNID, $p$-value $=0.6646$

All Standby TDP FTRlt1 H 9/12/2019

Figure 10. Frequency of run $\leq 1$ H hours (hours per reactor year) trend for standby TDPs. 


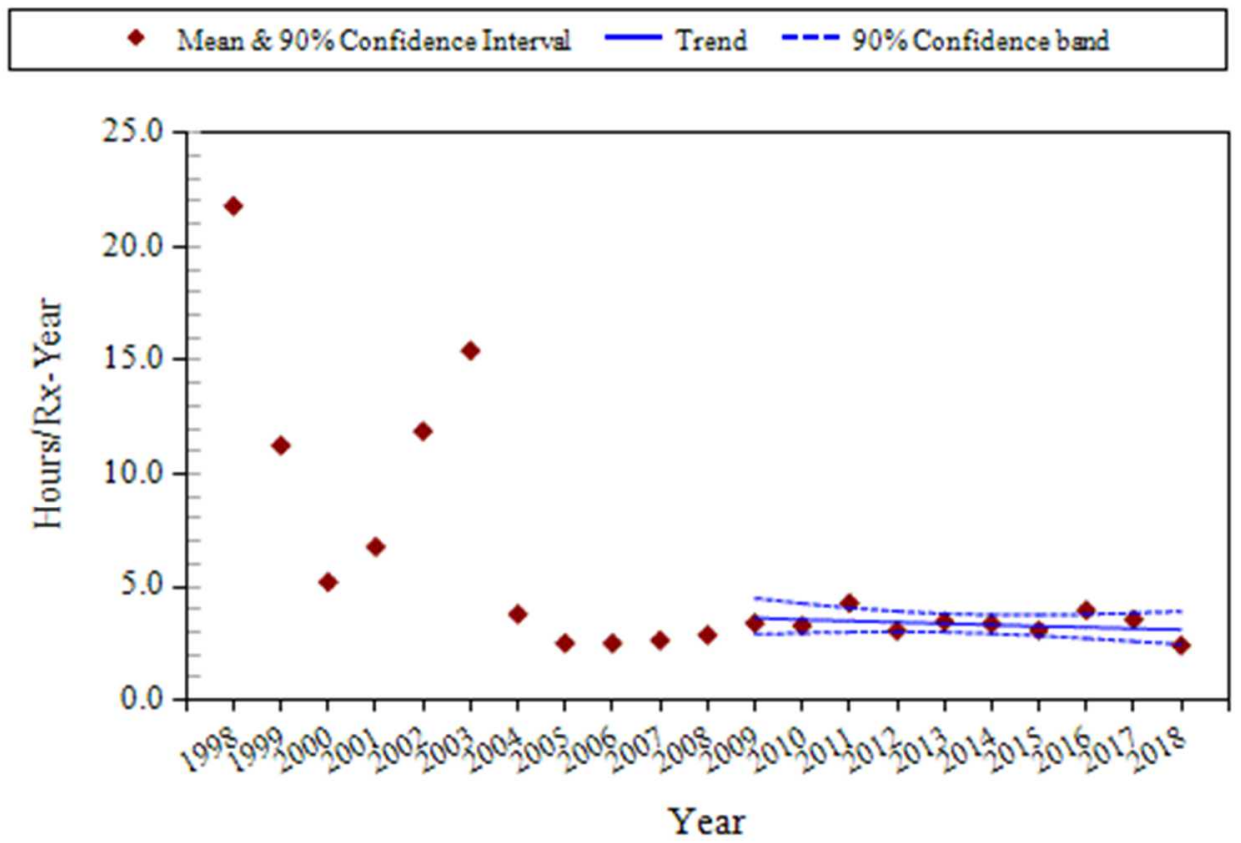

CNID, $p$-value $=0.3479$

All Standby TDP FTRgtl $9 / 12 / 2019$

Figure 11. Frequency of run $>1$ H hours (hours per reactor year) trend for standby TDPS.

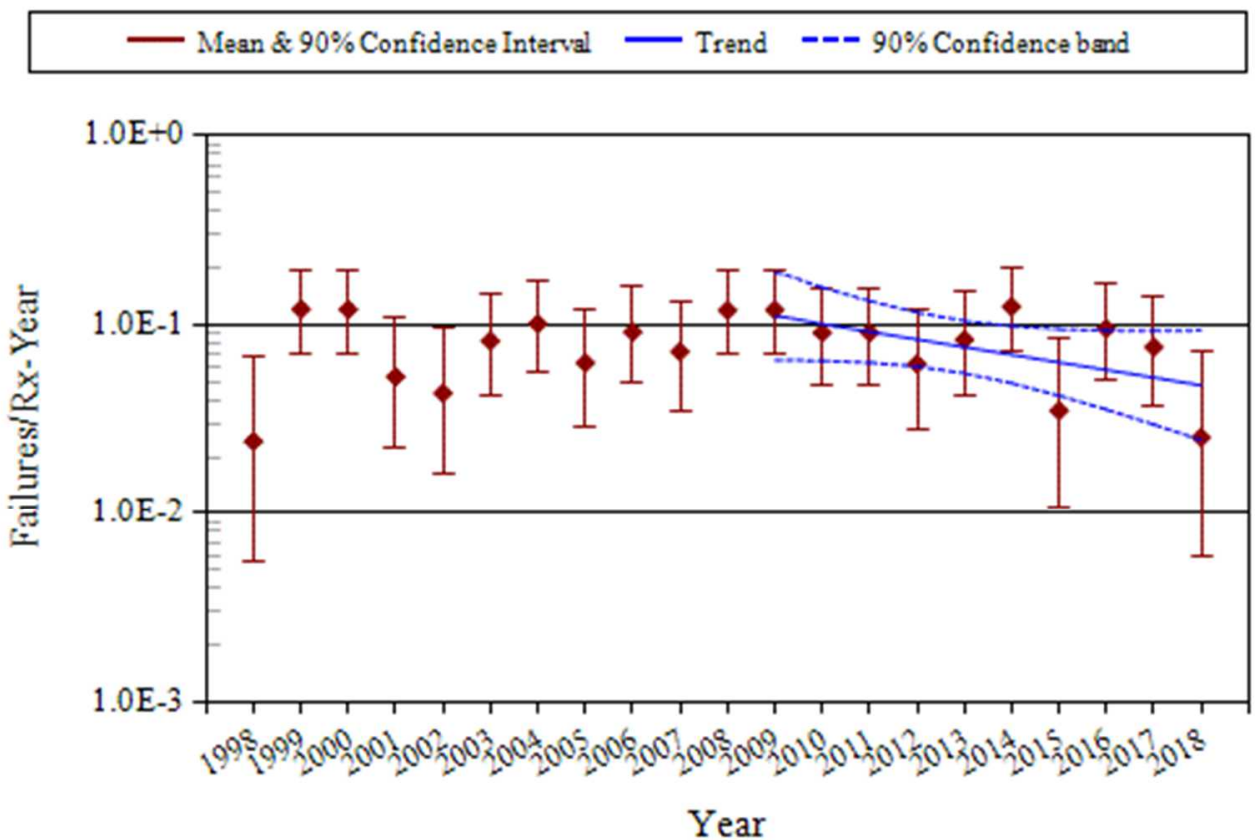

CNID, $p$-value $=0.0729$

All Standby TDP FTS 9/12/2019

Figure 12. Frequency of FTS events (events per reactor year) trend for standby TDPs. 


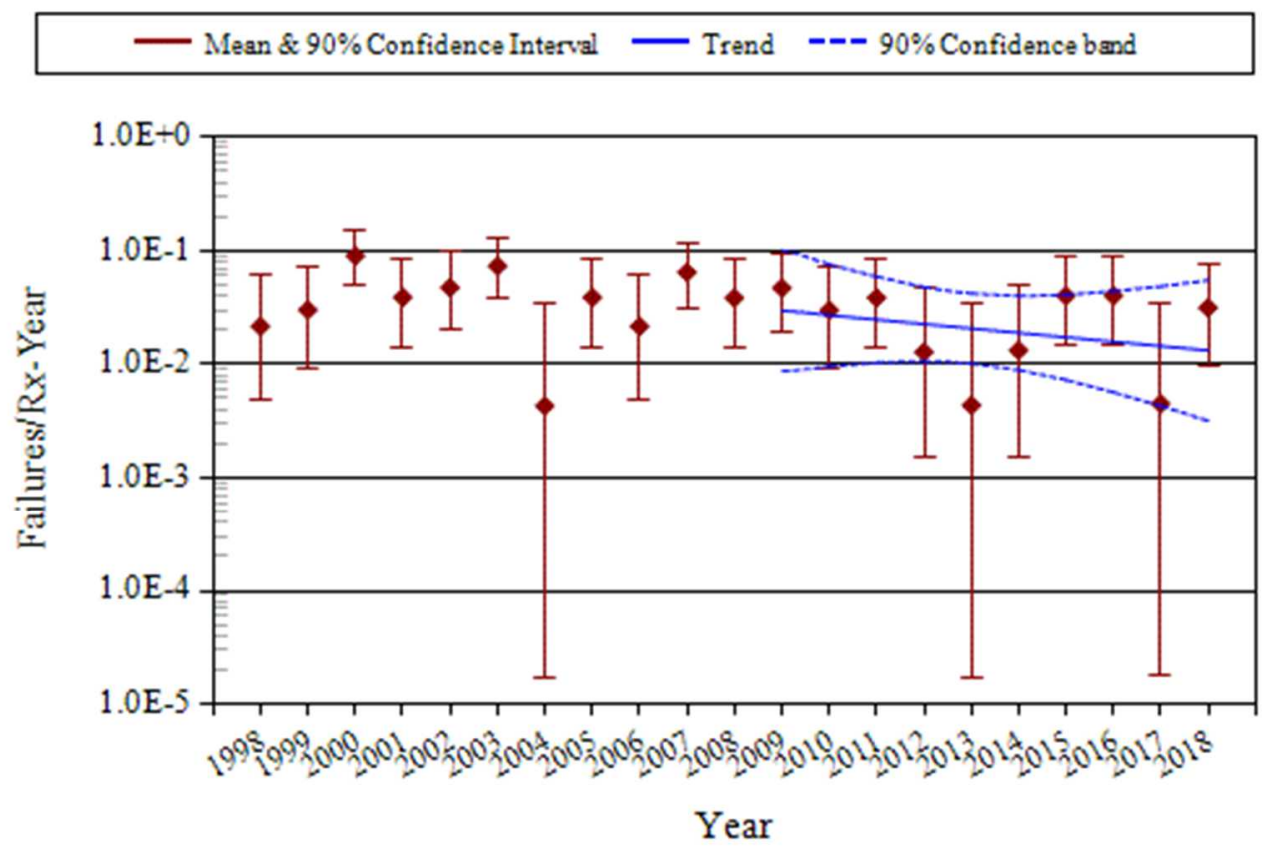

CNID, $p$-value $=0.3962$

All Standby TDP FTRlt1 H 9/12/2019

Figure 13. Frequency of FTR $\leq 1 \mathrm{H}$ events (events per reactor year) trend for standby TDPs.

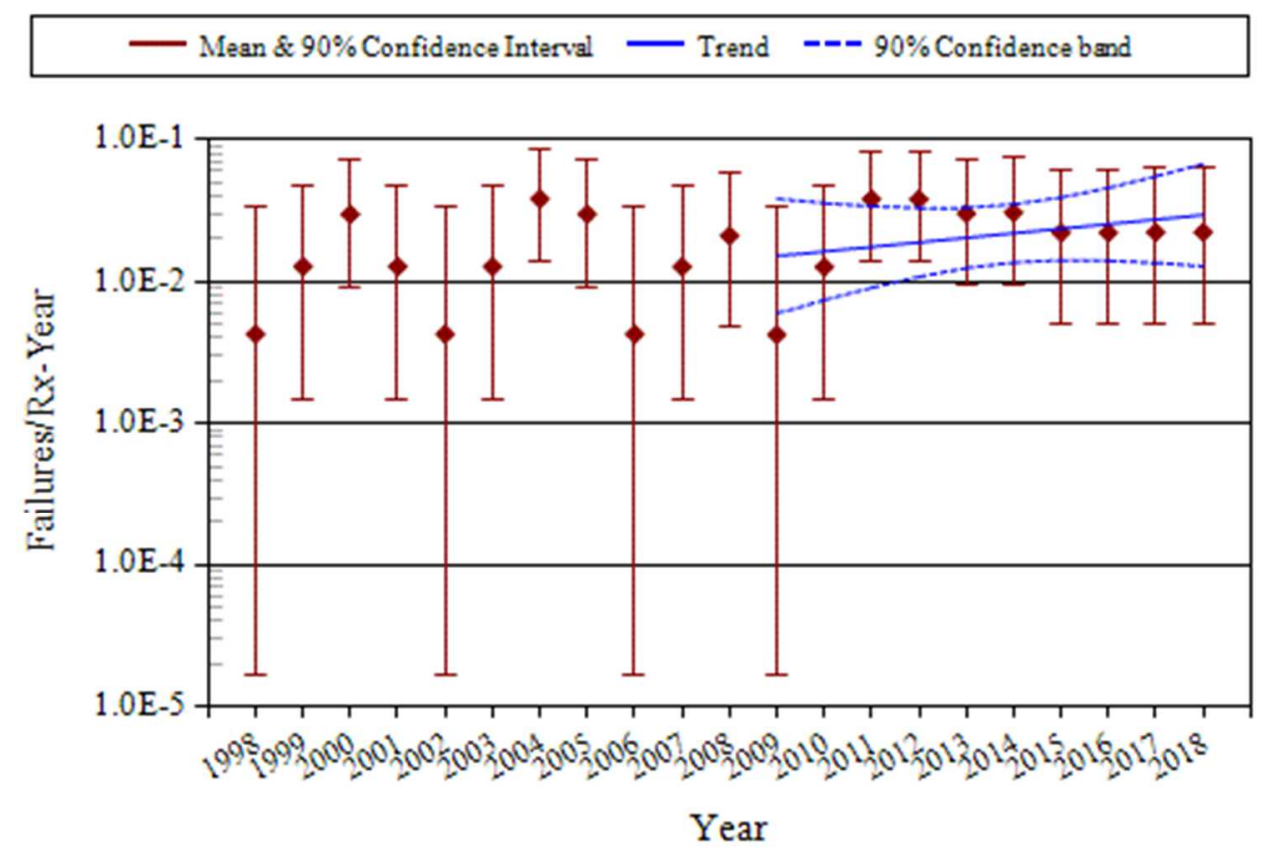

CNID, $p$-value $=0.2945$

All Standby TDP FTRgtlH 9/12/2019

Figure 14. Frequency of FTR $>1 \mathrm{H}$ events (events per reactor year) trend for standby TDPs. 
Table 4. Summary of TDP failure counts for the FTS failure mode over time by system.

\begin{tabular}{|c|c|c|c|c|c|c|c|c|c|c|c|c|c|c|}
\hline $\begin{array}{c}\text { System } \\
\text { Code }\end{array}$ & $\begin{array}{l}\text { TDP } \\
\text { Count }\end{array}$ & $\begin{array}{c}\text { TDP } \\
\text { Percent }\end{array}$ & 2009 & 2010 & 2011 & 2012 & 2013 & 2014 & 2015 & 2016 & 2017 & 2018 & Total & $\begin{array}{c}\text { Percent } \\
\text { of } \\
\text { Failures }\end{array}$ \\
\hline AFW & 74 & $42.0 \%$ & 6 & 5 & 4 & 2 & 4 & 11 & 2 & 2 & 4 & 1 & 41 & $50.6 \%$ \\
\hline $\mathrm{HPCl}$ & 28 & $15.9 \%$ & 4 & 2 & 4 & 1 & 3 & & & 4 & 1 & 1 & 20 & $24.7 \%$ \\
\hline MFW & 43 & $24.4 \%$ & 1 & & & 1 & 1 & & & 1 & & & 4 & $4.9 \%$ \\
\hline $\mathrm{RCIC}$ & 31 & $17.6 \%$ & 2 & 2 & 1 & 3 & 1 & 1 & 1 & 3 & 2 & & 16 & $19.8 \%$ \\
\hline Total & 176 & $100.0 \%$ & 13 & 9 & 9 & 7 & 9 & 12 & 3 & 10 & 7 & 2 & 81 & $100.0 \%$ \\
\hline
\end{tabular}

Table 5. Summary of TDP failure counts for the FTR $\leq 1 \mathrm{H}$ failure mode over time by system.

\begin{tabular}{|c|c|c|c|c|c|c|c|c|c|c|c|c|c|c|}
\hline $\begin{array}{c}\text { System } \\
\text { Code }\end{array}$ & $\begin{array}{l}\text { TDP } \\
\text { Count }\end{array}$ & $\begin{array}{c}\text { TDP } \\
\text { Percent }\end{array}$ & 2009 & 2010 & 2011 & 2012 & 2013 & 2014 & 2015 & 2016 & 2017 & 2018 & Total & $\begin{array}{c}\begin{array}{c}\text { Percent } \\
\text { of } \\
\text { Failures }\end{array}\end{array}$ \\
\hline AFW & 74 & $55.6 \%$ & 4 & 2 & 2 & & & 1 & 3 & 1 & & 1 & 14 & $56.0 \%$ \\
\hline $\mathrm{HPCl}$ & 28 & $21.1 \%$ & 1 & & & & & & 1 & 2 & & & 4 & $16.0 \%$ \\
\hline $\mathrm{RCIC}$ & 31 & $23.3 \%$ & & 1 & 2 & 1 & & & & 1 & & 2 & 7 & $28.0 \%$ \\
\hline Total & 133 & $100.0 \%$ & 5 & 3 & 4 & 1 & 0 & 1 & 4 & 4 & 0 & 3 & 25 & $100.0 \%$ \\
\hline
\end{tabular}

Table 6. Summary of TDP failure counts for the FTR $>1 H$ and FTR failure mode over time by system.

\begin{tabular}{|c|c|c|c|c|c|c|c|c|c|c|c|c|c|c|}
\hline $\begin{array}{c}\text { System } \\
\text { Code }\end{array}$ & $\begin{array}{l}\text { TDP } \\
\text { Count }\end{array}$ & $\begin{array}{c}\text { TDP } \\
\text { Percent }\end{array}$ & 2009 & 2010 & 2011 & 2012 & 2013 & 2014 & 2015 & 2016 & 2017 & 2018 & Total & $\begin{array}{c}\begin{array}{c}\text { Percent } \\
\text { of } \\
\text { Failures }\end{array}\end{array}$ \\
\hline AFW & 74 & $42.0 \%$ & & & 2 & 3 & 1 & 2 & 2 & & 1 & 2 & 13 & $22.8 \%$ \\
\hline $\mathrm{HPCl}$ & 28 & $15.9 \%$ & & 1 & 2 & & 1 & & & 1 & & & 5 & $8.8 \%$ \\
\hline MFW & 43 & $24.4 \%$ & 3 & 6 & 2 & 6 & 4 & 2 & 4 & 2 & 3 & 2 & 34 & $59.6 \%$ \\
\hline $\mathrm{RCIC}$ & 31 & $17.6 \%$ & & & & 1 & 1 & 1 & & 1 & 1 & & 5 & $8.8 \%$ \\
\hline Total & 176 & $100.0 \%$ & 3 & 7 & 6 & 10 & 7 & 5 & 6 & 4 & 5 & 4 & 57 & $100.0 \%$ \\
\hline
\end{tabular}

\subsection{Normally Running TDP Engineering Trends}

This section presents frequency trends for normally running TDP failures and demands.

- Figure 15 shows the trend for normally running TDP frequency of start demands (demands per reactor year).

- Figure 16 shows the trend for normally running TDP run hours per reactor year.

- Figure 17 shows the trend for normally running TDP frequency of FTS events (i.e., FTS events per reactor year).

- Figure 18 shows the trend for normally running TDP FTR events per reactor year.

The data for the above figures are provided in Section 8 . The normally running system (MFW) from Table 2 is trended for each figure.

In the lower left hand corner of the above trend figure, the regression p-values are reported. A review of these p-values shows that there are no statistically significant trends existing in the normally running TDP engineering trends for the most recent 10 -year period. 


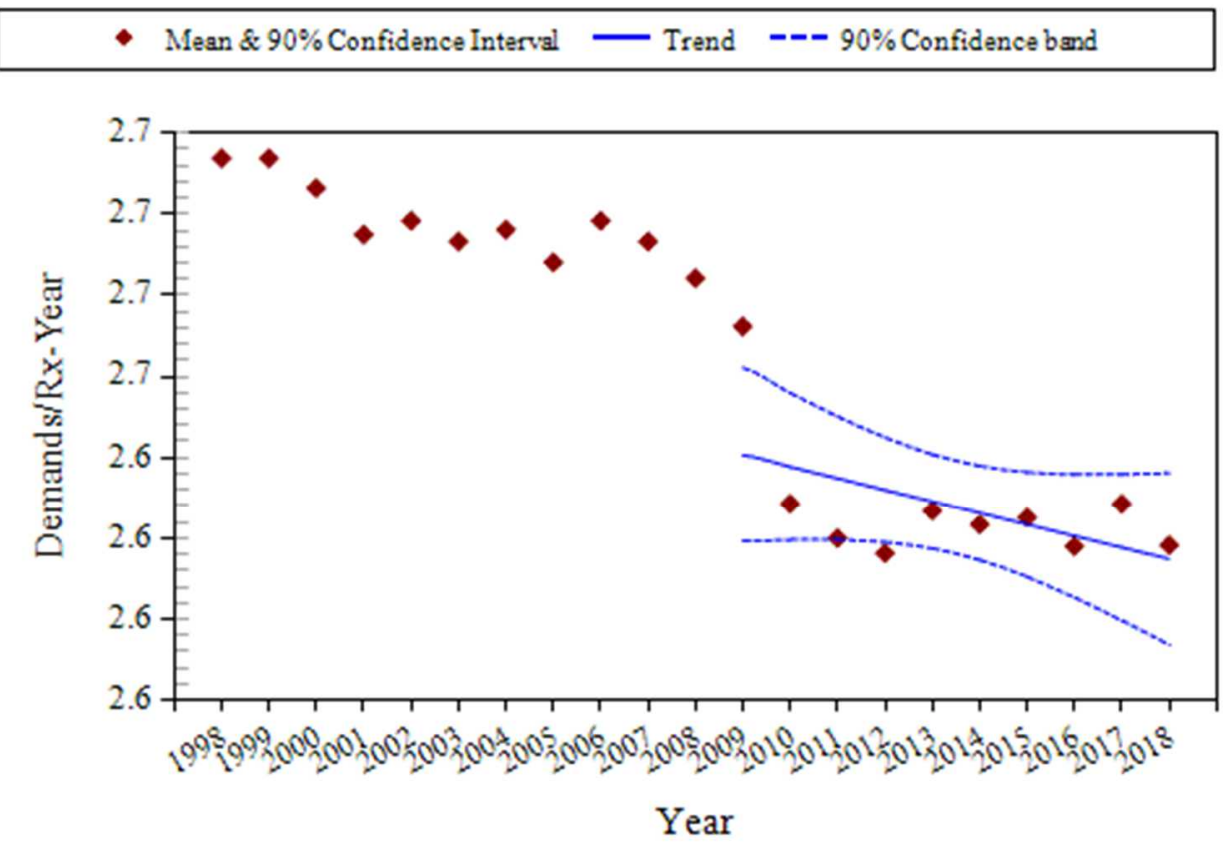

CNID, $p$-value $=0.1126$

All Normally Running TDP FTS 9/12/2019

Figure 15. Frequency of start demands (demands per reactor year) trend for normally running TDPs.

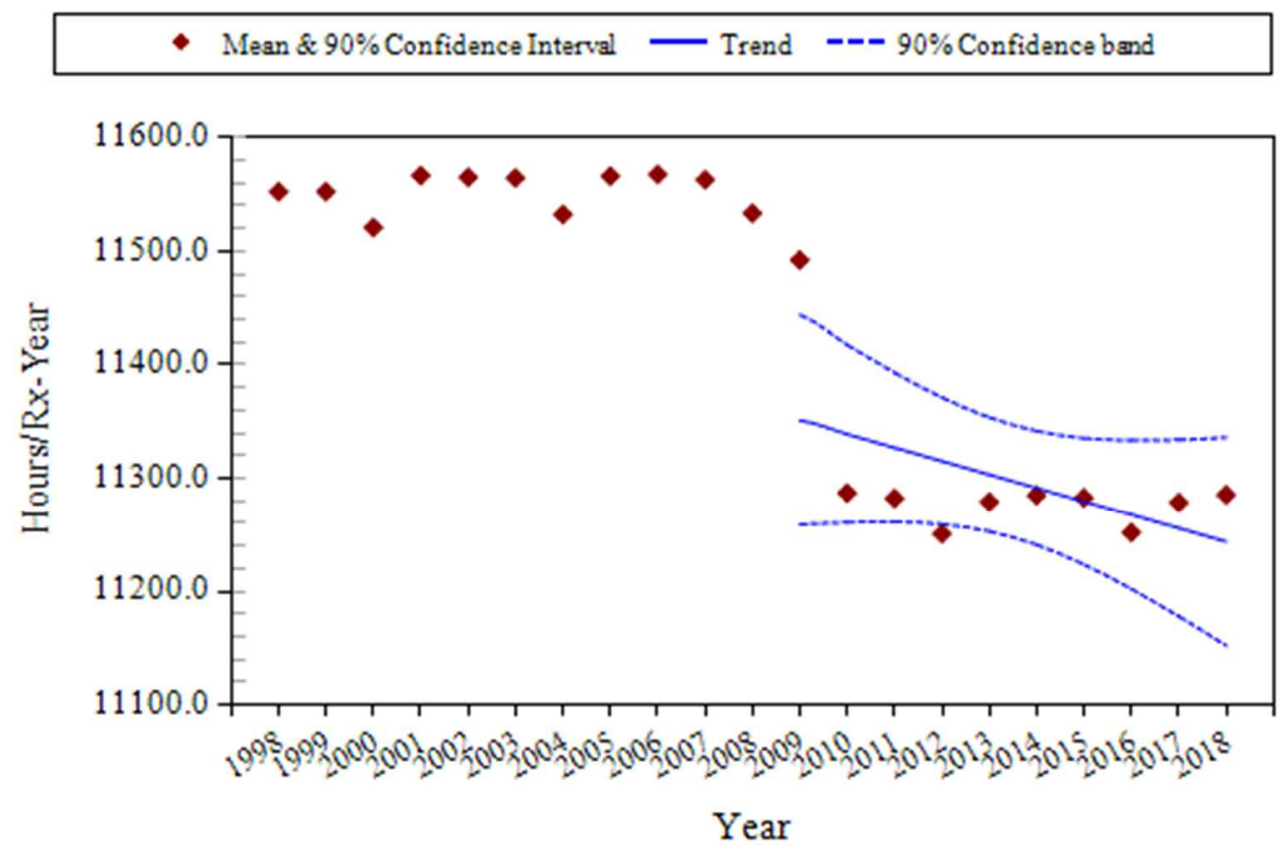

CNID, p-value $=0.1243$

All Normally Running TDP FTR 9/12/2019

Figure 16. Frequency of run hours (hours per reactor year) trend for normally running TDPs. 


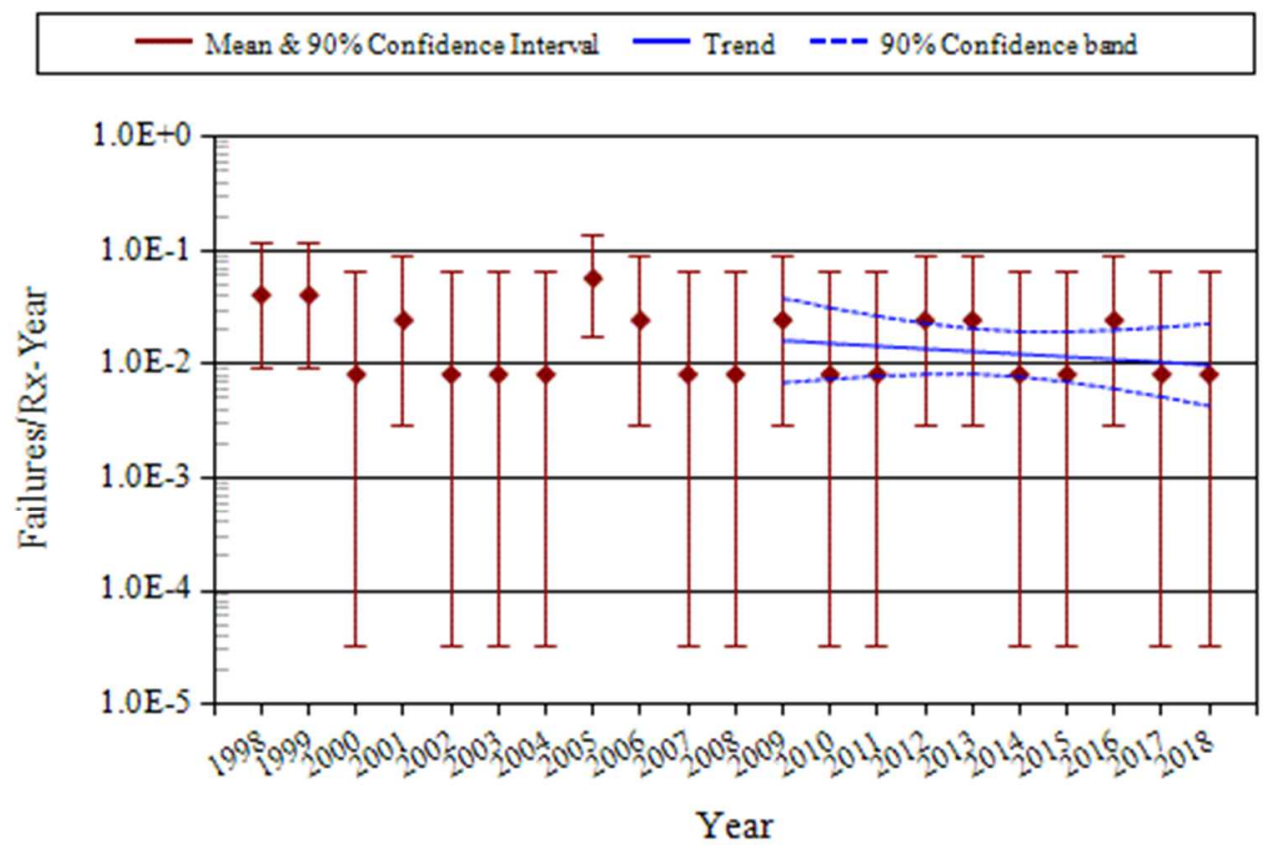

CNID, $p$-value $=0.4180$

All Normally Running TDP FTS $9 / 12 / 2019$

Figure 17. Frequency of FTS events (events per reactor year) trend for normally running TDPS.

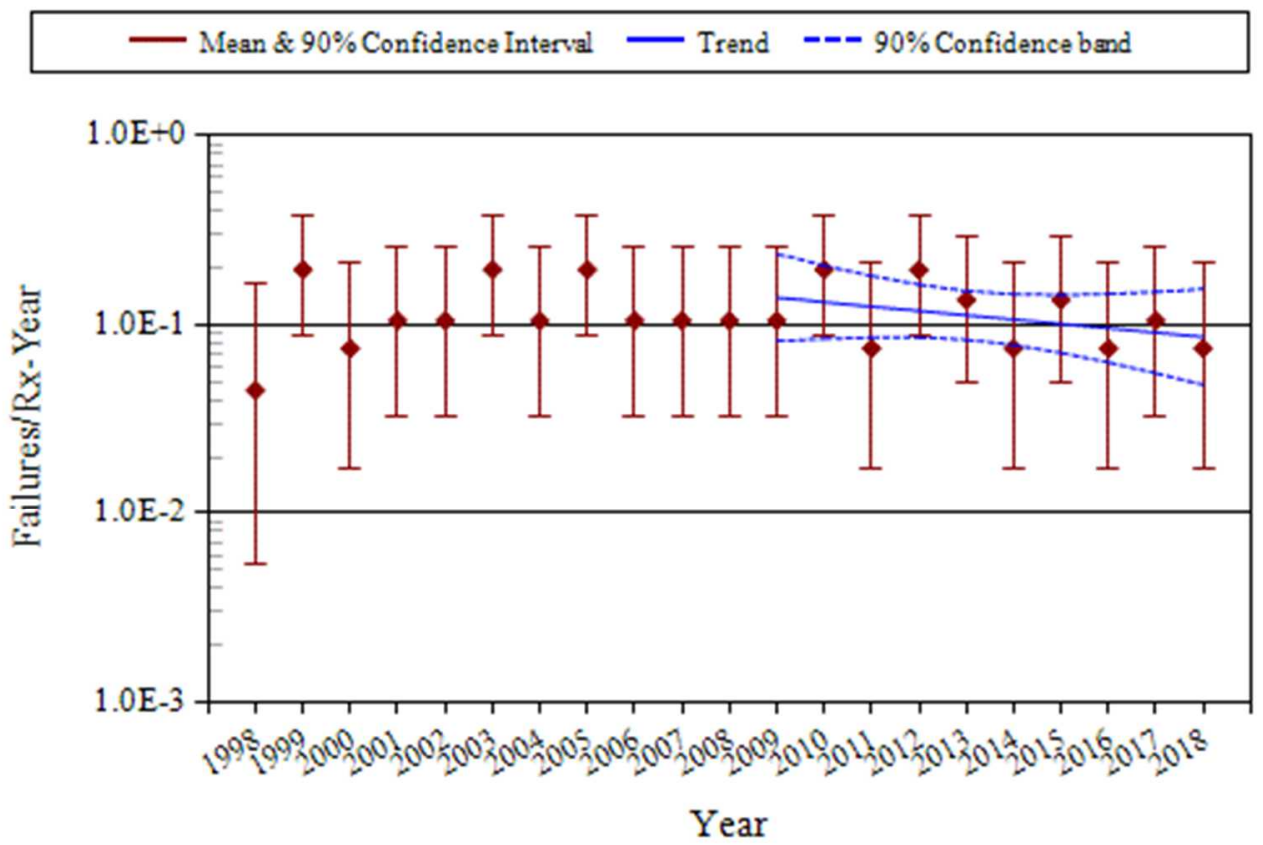

CNID, $p$-value $=0.2410$

All Normally Running TDP FTR 9/12/2019

Figure 18. Frequency of FTR events (events per reactor year) trend for normally running TDPs. 


\subsection{Comparison of ICES TDP Unplanned Demand Results with Industry Results}

An ongoing concern in the industry is whether a combination of test, non-test demand, and actual demand data adequately represents standby component performance during unplanned demands. This comparison evaluates the same dataset for standby components that is used for the overall trends shown in this document, but limits the failure data to those that are discovered during an ESF demand and the ESF demands reported in ICES. The data are further limited to 2003 to present since the ESF demand reporting in ICES is inconsistent prior to 2003.

The standby TDP ESF unplanned demand data covering 2003 through 2018 are summarized in Table 7. Consistency between the unplanned demand data and 2015 Update industry-average performance from Table 2 was evaluated using the predictive distribution approach outlined in the Handbook of Parameter Estimation for PRA, NUREG/CR-6823, Sections 6.2.3.5 and 6.3.3.4 [8].

The unplanned demand data were aggregated at the plant and system level (failures and demands). Assuming each plant and system can have a different failure probability, the industry-average distribution (from Table 2) was sampled for each plant and system. The predicted number of failure events for each plant and system was evaluated using the binomial distribution with the plant-specific failure probability and its associated number of demands. Then the total number of predicted failures was obtained by summing the individual plant results. This process was repeated 1000 times, each time obtaining a total number of predicted failures. The 1000 sample results were ordered from high to low. Then the actual number of unplanned demand failures observed (listed in the "Observed Failures" column of Table 7) was compared with this sample to determine the probability of observing this number of failures or greater. If the probability was greater than 0.05 and less than 0.95 , then the unplanned demand performance was considered to be consistent with the industry-average distribution obtained from the ICES data analysis.

Table 7. Standby TDP unplanned demand performance comparison with industry-average performance.

\begin{tabular}{ccccccc}
\hline Failure Modes & Plants & $\begin{array}{c}\text { Demands } \\
\text { or Hours }\end{array}$ & $\begin{array}{c}\text { Observed } \\
\text { Failures }\end{array}$ & $\begin{array}{c}\text { Expected } \\
\text { Failures }\end{array}$ & $\begin{array}{c}\text { Probability } \\
\text { of } \\
\text { ? Failures }\end{array}$ & $\begin{array}{c}\text { Consistent with } \\
\text { Industry-Average } \\
\text { Performance? }\end{array}$ \\
\hline FTS & 98 & 717 & 4 & 4.3 & 0.45 & Yes \\
FTR $\leq 1 \mathrm{H}$ & 98 & 450 & 7 & 1.7 & 0.05 & No \\
FTR $>1 \mathrm{H}$ & 98 & 1103 & 1 & 2.4 & 0.90 & Yes
\end{tabular}

a. If the probability of observing the actual failures or greater is $\geq 0.05$ and $\leq 0.95$, then the observed failure count is considered to be consistent with the industry-average performance.

These consistency checks show that the FTS and FTR $>1 \mathrm{H}$ failure observations in the non-test, operational ESF demand data lie within their corresponding industry-average failure estimate distributions, provided in the 2015 Update (Table 2), that were based on both test and non-test operational ESF demands. However, the FTR $\leq 1 \mathrm{H}$ failure observations are not consistent with the industry-average failure estimate distributions, which means that the TDP performs worse on a non-test, operational ESF demand than on a test demand. 


\subsection{TDP Engineering Analysis by Failure Modes}

The engineering analysis of TDP failure sub-components, causes, detection methods, and recovery possibility are presented in this section. First, each analysis divides the events into two categories: standby and normally running TDPs. Note that the FTR $\leq 1 \mathrm{H}$ failure mode only applies to standby TDPs and therefore only shows the Standby category data.

The second division of the events is by the failure mode determined after ICES data review by the Idaho National Laboratory (INL) staff. See Section 7 for more description of failure modes.

TDP sub-component contributions to the three failure modes are presented in Figure 19. The subcomponent categories are similar to those used in the CCF database. The driver (specifically the governor) has the highest percentage contributions to failures for all the failure modes.

TDP failure cause group contributions to the three failure modes are presented in Figure 20. The cause groups have been re-arranged in this update study in order to align with those currently used in the CCF database. Table 8 shows the breakdown of the cause groups with the specific causes that were coded during the data collection. The most likely causes are human errors, design issues, and component issues. The Human cause group is primarily influenced by maintenance and operating procedures and practices. The Component cause group includes the causes that were related to something internal to the component or an aging or worn out part, which were categorized as the Internal cause group in previous studies [2]. The Design cause group is influenced by manufacturing, installation, and design issues.

TDP failure detection methods for the three failure modes are presented in Figure 21. There are differences in the detection method based on the standby and normally running categories.

Standby - the most likely detection method for all three failure modes is testing. Inspection is also important for the FTS failure mode. The incidence of inspection for the FTS failure mode indicates that the equipment was observed to be unable to start without a demand (e.g., an alarmed condition, leaking oil, state of another component, etc.).

Normally running - the most likely detection method for FTR is non-testing. The prevalent FTS detection is non-test demands.

TDP recovery fractions for the three failure modes are presented in Figure 22. The overall nonrecovery to recovery ratio is approximately $6: 1$, meaning that 6 of every 7 failures were not recovered. 
Table 8. Component failure cause groups. ${ }^{a}$

\begin{tabular}{|c|c|c|}
\hline Group & Specific Cause & Description \\
\hline \multirow[t]{3}{*}{ Component } & $\begin{array}{l}\text { Internal to component, } \\
\text { piece-part }\end{array}$ & $\begin{array}{l}\text { Used when the cause of a failure is a non-specific result } \\
\text { of a failure internal to the component that failed other } \\
\text { than aging or wear. }\end{array}$ \\
\hline & Set point drift & $\begin{array}{l}\text { Used when the cause of a failure is the result of set } \\
\text { point drift or adjustment. }\end{array}$ \\
\hline & Age/Wear & $\begin{array}{l}\text { Used when the cause of the failure is a non-specific } \\
\text { aging or wear issue. }\end{array}$ \\
\hline \multirow[t]{3}{*}{ Design } & $\begin{array}{l}\text { Construction/installation } \\
\text { error or inadequacy }\end{array}$ & $\begin{array}{l}\text { Used when a construction or installation error is made } \\
\text { during the original or modification installation. This } \\
\text { includes specification of incorrect component or } \\
\text { material. }\end{array}$ \\
\hline & $\begin{array}{l}\text { Design error or } \\
\text { inadequacy }\end{array}$ & Used when a design error is made. \\
\hline & $\begin{array}{l}\text { Manufacturing error or } \\
\text { inadequacy }\end{array}$ & $\begin{array}{l}\text { Used when a manufacturing error is made during } \\
\text { component manufacture. }\end{array}$ \\
\hline \multirow[t]{3}{*}{ Environment } & $\begin{array}{l}\text { Ambient environmental } \\
\text { stress }\end{array}$ & $\begin{array}{l}\text { Used when the cause of a failure is the result of an } \\
\text { environmental condition from the location of the } \\
\text { component. }\end{array}$ \\
\hline & Internal environment & $\begin{array}{l}\text { The internal environment led to the failure. } \\
\text { Debris/Foreign material as well as an operating medium } \\
\text { chemistry issue. }\end{array}$ \\
\hline & $\begin{array}{l}\text { Extreme environmental } \\
\text { stress }\end{array}$ & $\begin{array}{l}\text { Used when the cause of a failure is the result of an } \\
\text { environmental condition that places a higher than } \\
\text { expected load on the equipment and is transitory in } \\
\text { nature. }\end{array}$ \\
\hline \multirow[t]{4}{*}{ Human } & $\begin{array}{l}\text { Accidental action } \\
\text { (unintentional or undesired } \\
\text { human errors) }\end{array}$ & $\begin{array}{l}\text { Used when a human error (during the performance of an } \\
\text { activity) results in an unintentional or undesired action. }\end{array}$ \\
\hline & Human action procedure & $\begin{array}{l}\text { Used when the correct procedure is not followed or the } \\
\text { wrong procedure is followed. For example: when a } \\
\text { missed step or incorrect step in a surveillance procedure } \\
\text { results in a component failure. }\end{array}$ \\
\hline & Inadequate maintenance & $\begin{array}{l}\text { Used when a human error (during the performance of } \\
\text { maintenance) results in an unintentional or undesired } \\
\text { action. }\end{array}$ \\
\hline & Inadequate procedure & $\begin{array}{l}\text { Used when the cause of a failure is the result of an } \\
\text { inadequate procedure operating or maintenance. }\end{array}$ \\
\hline \multirow[t]{3}{*}{ Other } & State of other component & $\begin{array}{l}\text { Used when the cause of a failure is the result of a } \\
\text { component state that is not associated with the } \\
\text { component that failed. An example would be the diesel } \\
\text { failed due to empty fuel storage tanks. }\end{array}$ \\
\hline & $\begin{array}{l}\text { Other (stated cause does } \\
\text { not fit other categories) }\end{array}$ & $\begin{array}{l}\text { Used when the cause of a failure is provided but it does } \\
\text { not meet any one of the descriptions. }\end{array}$ \\
\hline & Unknown & Used when the cause of the failure is not known. \\
\hline
\end{tabular}

\footnotetext{
a . The cause groups have been re-arranged in order to align with those currently used in the CCF database. 

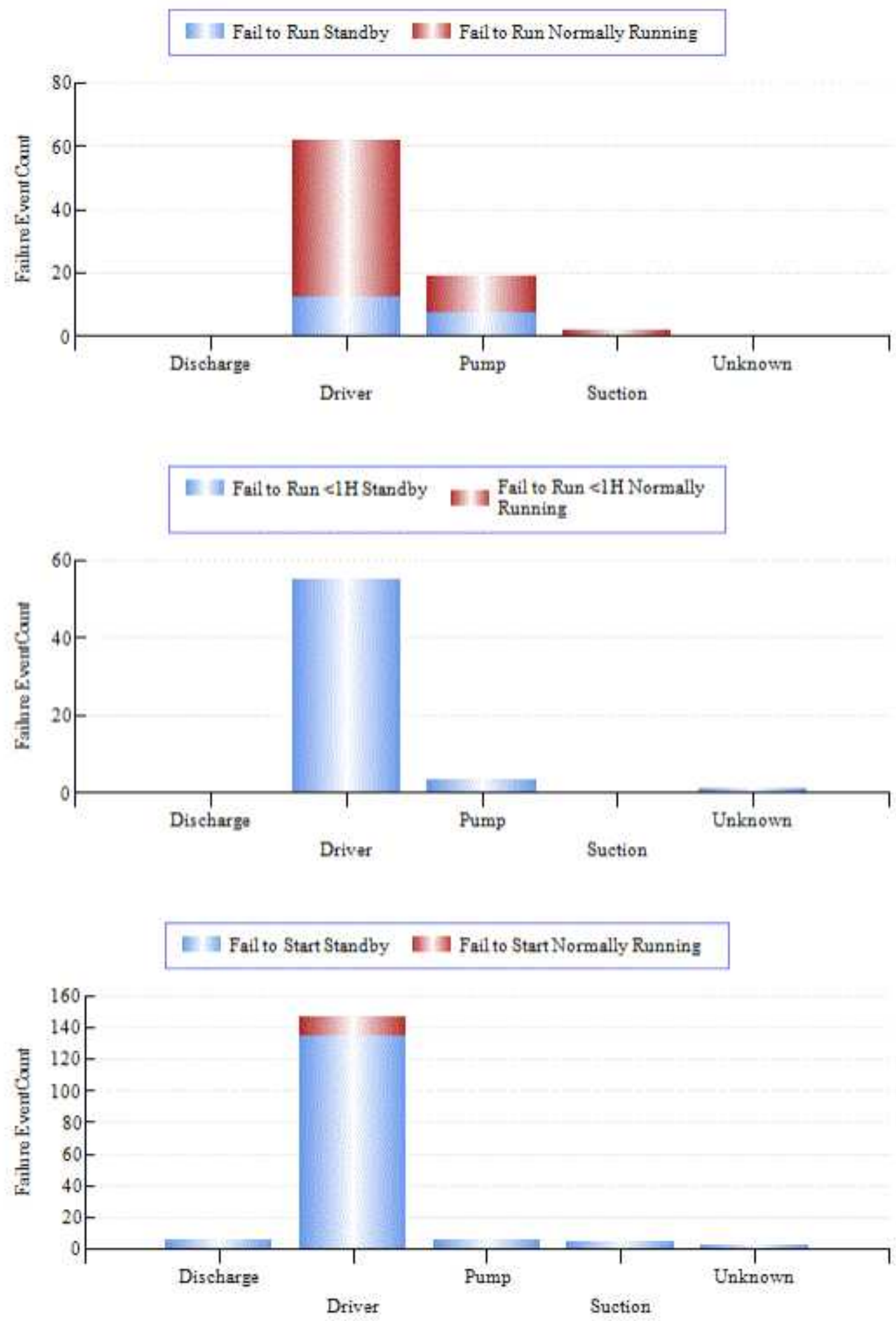

Figure 19. TDP failure event breakdown by subcomponent, failure mode, and operational status. 

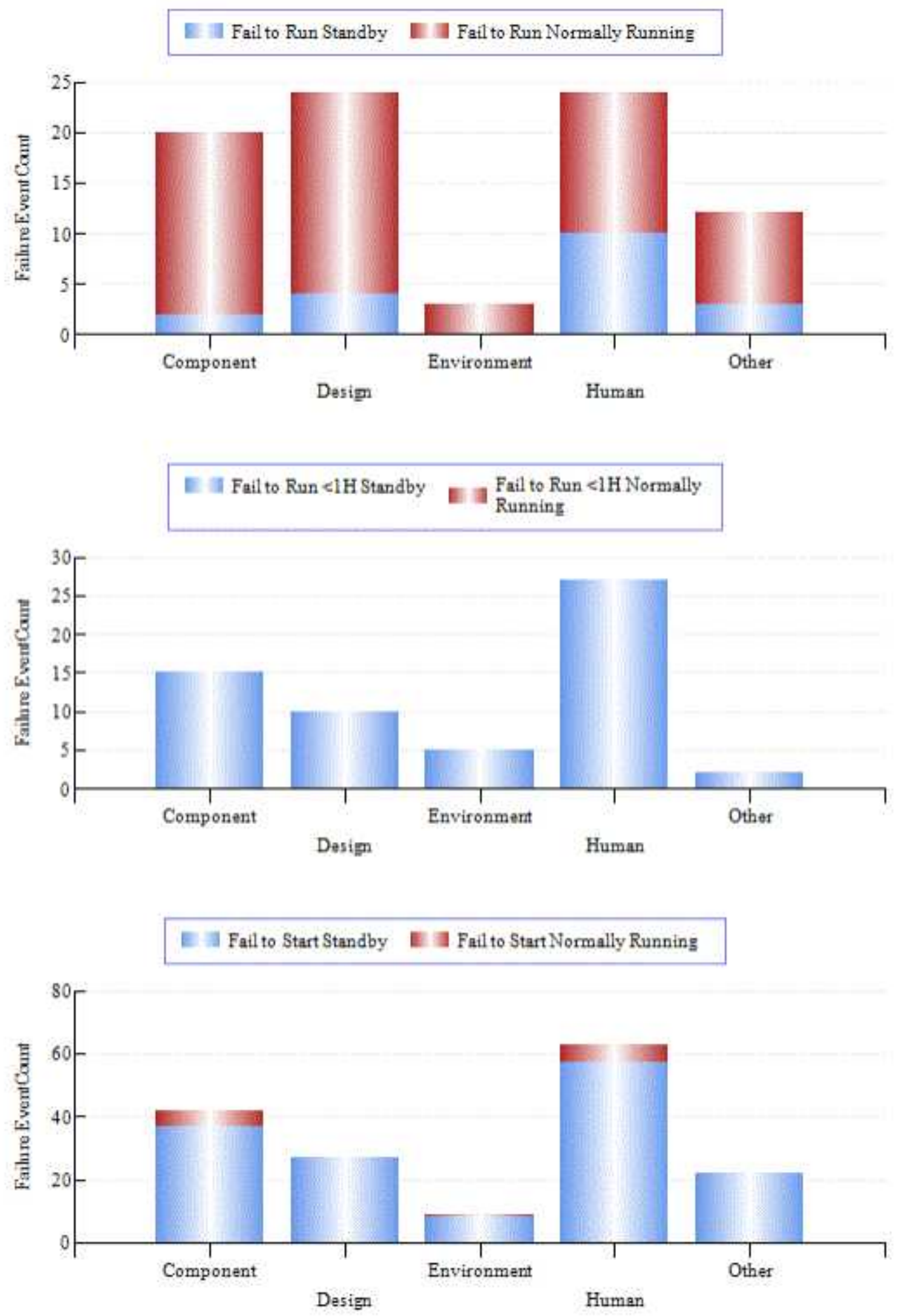

Figure 20. TDP failure event breakdown by cause group, failure mode, and operational status. 

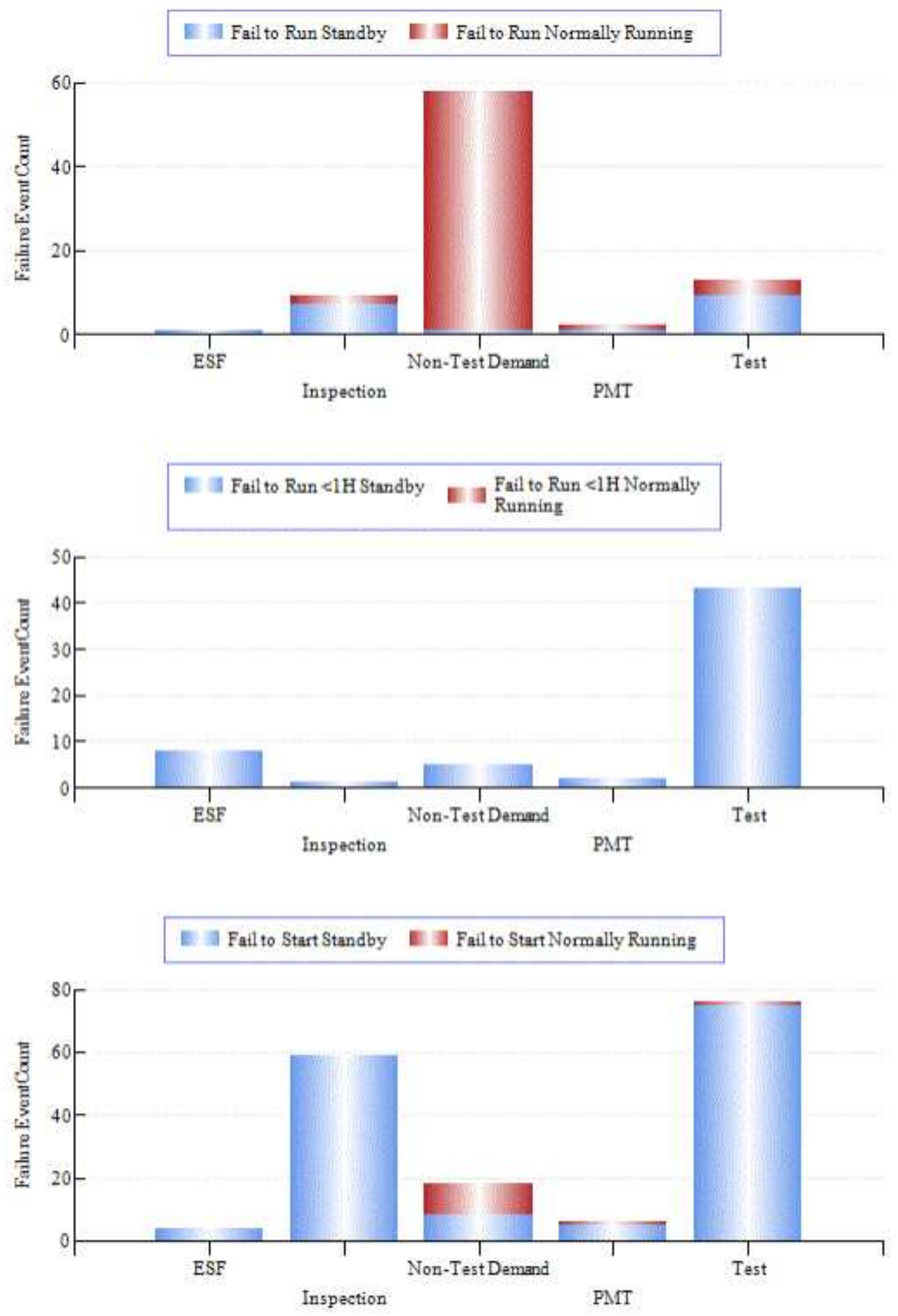

Figure 21. TDP failure event breakdown by failure detection method, failure mode, and operational status. 

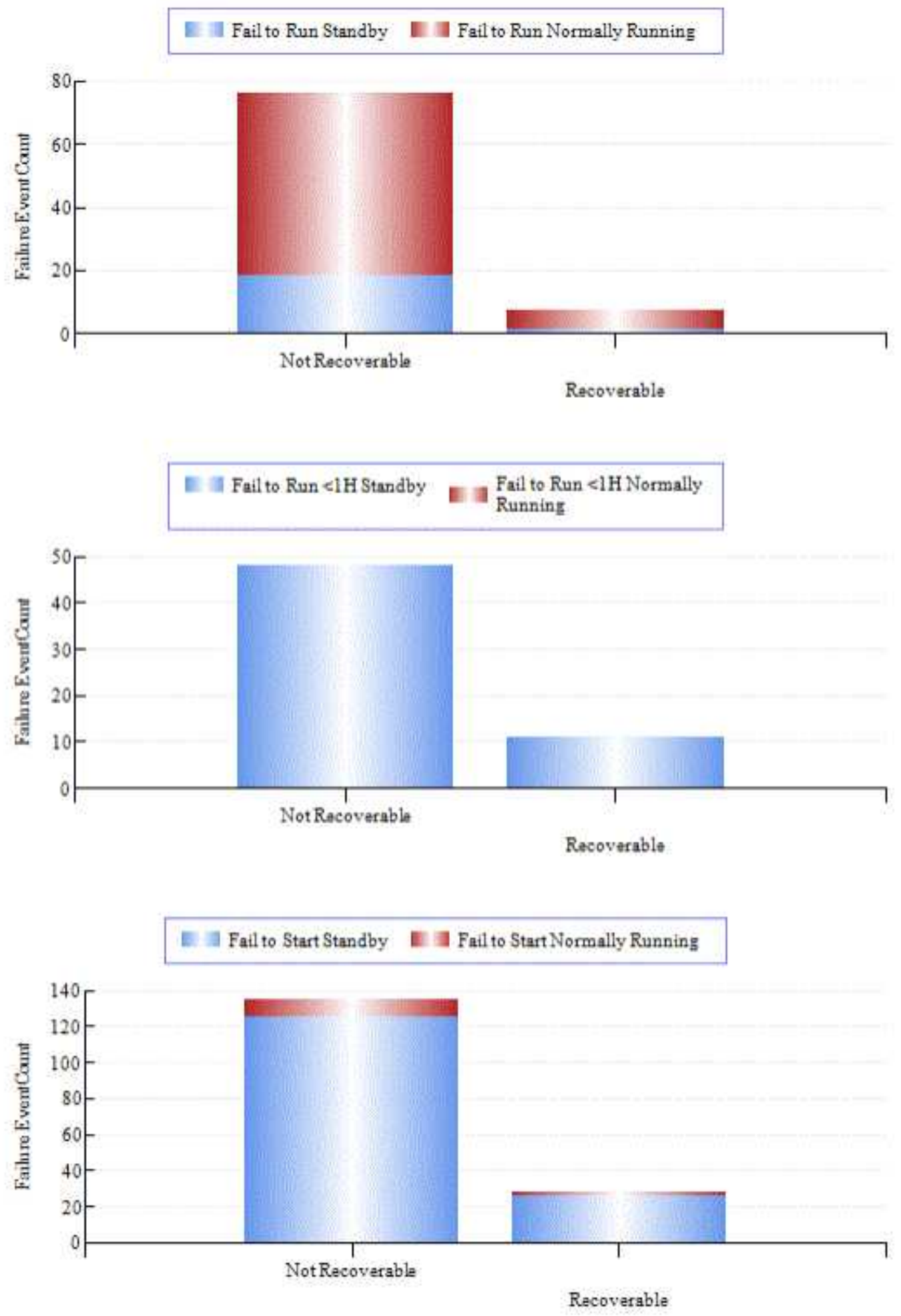

Figure 22. TDP failure event breakdown by recoverability determination, failure mode, and operational status. 


\section{TDP ASSEMBLY DESCRIPTION}

The TDP is generally comprised of a pump, a turbine driver, and a governor. Most plant designs use a single stage "Terry Turbine", whose piece-parts include a turbine trip and throttle valve, a mechanical over speed trip mechanism, and a lubrication system. The various types of governors used for turbine speed control are mostly manufactured by the Woodward Corporation. For the AFW system TDP, the governors are predominantly mechanical/hydraulic; pressure-compensated, and have a pneumatic remote speed-setting capability. For the RCIC and HPCI systems, the TDPs typically have a Woodward type EG-M electric/electronic governor and EGR hydraulic actuators. Piece-parts of all governors include a turbine stop valve and a governor valve, while the EG-M usually includes a ramp generator/signal converter and other electrical controls.

The TDP failure modes include FTS, FTR $\leq 1 \mathrm{H}$, and FTR $>1 \mathrm{H}$. These failure modes were used in NUREG/CR-6928 [7] and are similar to those used in the MSPI Program.

Guidelines for determining whether a component event reported in ICES is to be included in FTS, $\mathrm{FTR} \leq 1 \mathrm{H}$, or FTR $>1 \mathrm{H}$ are similar to those used in the MSPI Program. In general, any circumstance in which the component is not able to meet the performance requirements defined in the PRA is counted. This includes conditions revealed through testing, operational demands, unplanned demands, or discovery. Also, run failures that occur beyond the typical 24-hour mission time in PRAs are included. However, certain events are excluded: slow starting times that do not exceed the PRA success criteria, conditions that are annunciated immediately in the control room without a demand, and run events that are shown to not have caused an actual run failure within 24 hours. Also, events occurring during maintenance or post-maintenance testing that are related to the actual maintenance activities are excluded. All of the TDP events within ICES were reviewed to ensure that they were binned to the correct failure mode-FTS, FTR $\leq 1 \mathrm{H}, \mathrm{FTR}>1 \mathrm{H}$, or no failure. However, even given detailed descriptions of failure events, this binning still required some judgment and involves some uncertainty.

Guidelines for counting demands and run hours are similar to those in the MSPI Program. Start and run demands include those resulting from tests, operational demands, and unplanned demands. Demands during maintenance and post-maintenance testing are excluded. Similarly, run hours include those from tests, operational demands, and unplanned demands. 


\section{DATA TABLES}

In this section, the plot data for Figure 1 to Figure 18 in previous sections are provided in Table 9 to Table 26, respectively.

\begin{tabular}{|c|c|c|}
\hline Figure & Table & Analysis \\
\hline Figure 1 & Table 9 & Failure probability estimate trend for standby TDP FTS \\
\hline Figure 2 & Table 10 & Failure probability estimate trend for standby TDP FTR $\leq 1 \mathrm{H}$ \\
\hline Figure 3 & Table 11 & Failure rate estimate trend for standby TDP FTR $>1 \mathrm{H}$ \\
\hline Figure 4 & Table 12 & Failure probability estimate trend for normally running TDP FTS \\
\hline Figure 5 & Table 13 & Failure rate estimate trend for normally running TDP FTR \\
\hline Figure 6 & Table 14 & Pooled standby TDP UA trend \\
\hline Figure 7 & Table 15 & Standby TDP unreliability trend (8-hour mission) \\
\hline Figure 8 & Table 16 & Normally running TDP unreliability trend (8-hour mission) \\
\hline Figure 9 & Table 17 & Frequency of start demands (demands per reactor year) trend for standby TDPs \\
\hline Figure 10 & Table 18 & Frequency of run $\leq 1 \mathrm{H}$ hours (hours per reactor year) trend for standby TDPs \\
\hline Figure 11 & Table 19 & Frequency of run $>1 \mathrm{H}$ hours (hours per reactor year) trend for standby TDPs \\
\hline Figure 12 & Table 20 & Frequency of FTS events (events per reactor year) trend for standby TDPs \\
\hline Figure 13 & Table 21 & Frequency of FTR $\leq 1 \mathrm{H}$ events (events per reactor year) trend for standby TDPs \\
\hline Figure 14 & Table 22 & Frequency of FTR $>1 \mathrm{H}$ events (events per reactor year) trend for standby TDPs \\
\hline Figure 15 & Table 23 & Frequency of start demands (demands per reactor year) trend for normally running TDPs \\
\hline Figure 16 & Table 24 & Frequency of run hours (hours per reactor year) trend for normally running TDPs \\
\hline Figure 17 & Table 25 & Frequency of FTS events (events per reactor year) trend for normally running TDPs \\
\hline Figure 18 & Table 26 & Frequency of FTR events (events per reactor year) trend for normally running TDPs \\
\hline
\end{tabular}


Table 9. Plot data for Figure 1, failure probability estimate trend for standby TDP FTS.

\begin{tabular}{|c|c|c|c|c|c|c|c|c|}
\hline \multirow[b]{2}{*}{ Year } & \multirow[b]{2}{*}{ Failures } & \multirow[b]{2}{*}{ Demands } & \multicolumn{3}{|c|}{ Regression Curve Data Points } & \multicolumn{3}{|c|}{ Yearly Estimate Data Points } \\
\hline & & & Mean & $\begin{array}{c}\text { Lower } \\
(5 \%)\end{array}$ & $\begin{array}{l}\text { Upper } \\
(95 \%) \\
\end{array}$ & $\begin{array}{c}\text { Lower } \\
(5 \%)\end{array}$ & $\begin{array}{l}\text { Upper } \\
(95 \%)\end{array}$ & Mean \\
\hline \multicolumn{2}{|c|}{2015 Update } & & & & & 5.35E-04 & $1.62 \mathrm{E}-02$ & $5.93 E-03$ \\
\hline 1998 & 2 & 1,512 & -- & -- & -- & $3.56 \mathrm{E}-04$ & 4.36E-03 & $1.55 \mathrm{E}-03$ \\
\hline 1999 & 12 & 1,496 & -- & -- & -- & 4.59E-03 & 1.26E-02 & 7.84E-03 \\
\hline 2000 & 12 & 1,438 & -- & -- & -- & 4.76E-03 & 1.30E-02 & 8.14E-03 \\
\hline 2001 & 5 & 1,430 & -- & -- & -- & $1.50 \mathrm{E}-03$ & 7.31E-03 & 3.60E-03 \\
\hline 2002 & 4 & 1,395 & -- & -- & -- & $1.11 \mathrm{E}-03$ & $6.58 \mathrm{E}-03$ & $3.02 E-03$ \\
\hline 2003 & 8 & 1,518 & -- & -- & -- & 2.69E-03 & 9.31E-03 & 5.26E-03 \\
\hline 2004 & 10 & 1,447 & -- & -- & -- & 3.76E-03 & 1.14E-02 & $6.80 \mathrm{E}-03$ \\
\hline 2005 & 6 & 1,425 & -- & -- & -- & 1.94E-03 & 8.19E-03 & 4.27E-03 \\
\hline 2006 & 9 & 1,462 & -- & -- & -- & $3.25 \mathrm{E}-03$ & $1.05 E-02$ & 6.09E-03 \\
\hline 2007 & 7 & 1,381 & -- & -- & -- & 2.46E-03 & 9.31E-03 & 5.07E-03 \\
\hline 2008 & 12 & 1,446 & -- & -- & -- & 4.74E-03 & 1.30E-02 & 8.10E-03 \\
\hline 2009 & 12 & 1,543 & 6.98E-03 & 4.13E-03 & 1.18E-02 & 4.46E-03 & $1.22 \mathrm{E}-02$ & 7.62E-03 \\
\hline 2010 & 9 & 1,574 & 6.36E-03 & 4.09E-03 & $9.88 \mathrm{E}-03$ & 3.03E-03 & $9.75 \mathrm{E}-03$ & 5.68E-03 \\
\hline 2011 & 9 & 1,572 & 5.81E-03 & 4.00E-03 & 8.41E-03 & 3.03E-03 & $9.77 \mathrm{E}-03$ & 5.69E-03 \\
\hline 2012 & 6 & 1,501 & 5.30E-03 & 3.82E-03 & 7.34E-03 & $1.84 \mathrm{E}-03$ & 7.80E-03 & 4.07E-03 \\
\hline 2013 & 8 & 1,538 & 4.83E-03 & 3.52E-03 & 6.62E-03 & 2.65E-03 & 9.20E-03 & 5.20E-03 \\
\hline 2014 & 12 & 1,488 & 4.41E-03 & 3.12E-03 & $6.22 \mathrm{E}-03$ & 4.61E-03 & 1.26E-02 & 7.88E-03 \\
\hline 2015 & 3 & 1,510 & 4.02E-03 & 2.69E-03 & 6.01E-03 & 6.75E-04 & 5.26E-03 & 2.18E-03 \\
\hline 2016 & 9 & 1,485 & 3.67E-03 & 2.27E-03 & 5.93E-03 & $3.20 \mathrm{E}-03$ & 1.03E-02 & $6.00 \mathrm{E}-03$ \\
\hline 2017 & 7 & 1,449 & 3.34E-03 & 1.89E-03 & 5.91E-03 & 2.35E-03 & 8.90E-03 & $4.85 \mathrm{E}-03$ \\
\hline 2018 & 2 & 1,420 & 3.05E-03 & $1.56 \mathrm{E}-03$ & 5.94E-03 & 3.78E-04 & 4.63E-03 & 1.65E-03 \\
\hline Total & 164 & 31,031 & & & & & & \\
\hline
\end{tabular}


Table 10. Plot data for Figure 2, failure probability estimate trend for standby $T D P F T R \leq 1 H$.

\begin{tabular}{|c|c|c|c|c|c|c|c|c|}
\hline \multirow[b]{2}{*}{ Year } & \multirow[b]{2}{*}{ Failures } & \multirow[b]{2}{*}{ Demands } & \multicolumn{3}{|c|}{ Regression Curve Data Points } & \multicolumn{3}{|c|}{ Yearly Estimate Data Points } \\
\hline & & & Mean & $\begin{array}{c}\text { Lower } \\
(5 \%)\end{array}$ & $\begin{array}{l}\text { Upper } \\
(95 \%)\end{array}$ & $\begin{array}{c}\text { Lower } \\
(5 \%)\end{array}$ & $\begin{array}{l}\text { Upper } \\
(95 \%)\end{array}$ & Mean \\
\hline \multicolumn{2}{|c|}{2015 Update } & & & & & 1.51E-04 & 1.15E-02 & $3.71 \mathrm{E}-03$ \\
\hline 1998 & 2 & 1,512 & -- & -- & -- & 3.17E-04 & 3.89E-03 & 1.38E-03 \\
\hline 1999 & 3 & 1,496 & -- & -- & -- & $6.05 E-04$ & $4.72 \mathrm{E}-03$ & 1.95E-03 \\
\hline 2000 & 10 & 1,438 & -- & -- & -- & 3.34E-03 & 1.01E-02 & 6.06E-03 \\
\hline 2001 & 4 & 1,430 & -- & -- & -- & 9.63E-04 & 5.70E-03 & 2.61E-03 \\
\hline 2002 & 5 & 1,395 & -- & -- & -- & 1.35E-03 & 6.61E-03 & $3.25 \mathrm{E}-03$ \\
\hline 2003 & 8 & 1,518 & -- & -- & -- & 2.39E-03 & 8.31E-03 & 4.69E-03 \\
\hline 2004 & 0 & 1,447 & -- & -- & -- & 1.13E-06 & 2.24E-03 & 2.87E-04 \\
\hline 2005 & 4 & 1,425 & -- & -- & -- & 9.66E-04 & 5.72E-03 & 2.61E-03 \\
\hline 2006 & 2 & 1,462 & -- & -- & -- & 3.26E-04 & 4.00E-03 & $1.42 \mathrm{E}-03$ \\
\hline 2007 & 7 & 1,381 & -- & -- & -- & 2.17E-03 & 8.23E-03 & 4.47E-03 \\
\hline 2008 & 4 & 1,446 & -- & -- & -- & 9.54E-04 & 5.65E-03 & $2.58 \mathrm{E}-03$ \\
\hline 2009 & 5 & 1,543 & 1.87E-03 & 5.47E-04 & 6.37E-03 & 1.24E-03 & 6.08E-03 & $2.99 \mathrm{E}-03$ \\
\hline 2010 & 3 & 1,574 & 1.71E-03 & 6.07E-04 & 4.81E-03 & 5.80E-04 & 4.52E-03 & 1.87E-03 \\
\hline 2011 & 4 & 1,572 & 1.56E-03 & 6.54E-04 & 3.73E-03 & 8.90E-04 & 5.27E-03 & $2.41 \mathrm{E}-03$ \\
\hline 2012 & 1 & 1,501 & 1.43E-03 & 6.72E-04 & 3.04E-03 & 9.79E-05 & 3.08E-03 & 8.35E-04 \\
\hline 2013 & 0 & 1,538 & 1.31E-03 & 6.44E-04 & 2.66E-03 & 1.07E-06 & 2.13E-03 & 2.73E-04 \\
\hline 2014 & 1 & 1,488 & 1.20E-03 & 5.66E-04 & 2.54E-03 & 9.86E-05 & 3.10E-03 & 8.41E-04 \\
\hline 2015 & 4 & 1,510 & 1.10E-03 & 4.63E-04 & 2.60E-03 & 9.21E-04 & 5.45E-03 & 2.49E-03 \\
\hline 2016 & 4 & 1,485 & 1.00E-03 & 3.61E-04 & 2.79E-03 & 9.34E-04 & 5.52E-03 & 2.53E-03 \\
\hline 2017 & 0 & 1,449 & 9.19E-04 & 2.73E-04 & 3.09E-03 & 1.13E-06 & 2.24E-03 & 2.87E-04 \\
\hline 2018 & 3 & 1,420 & 8.41E-04 & 2.03E-04 & 3.49E-03 & 6.32E-04 & 4.93E-03 & 2.04E-03 \\
\hline Total & 74 & 31,031 & & & & & & \\
\hline
\end{tabular}


Table 11. Plot data for Figure 3, failure rate estimate trend for standby TDP FTR $>1 H$.

\begin{tabular}{|c|c|c|c|c|c|c|c|c|}
\hline \multirow[b]{2}{*}{ Year } & \multirow[b]{2}{*}{ Failures } & \multirow[b]{2}{*}{ Hours } & \multicolumn{3}{|c|}{ Regression Curve Data Points } & \multicolumn{3}{|c|}{ Yearly Estimate Data Points } \\
\hline & & & Mean & $\begin{array}{c}\text { Lower } \\
(5 \%)\end{array}$ & $\begin{array}{l}\text { Upper } \\
(95 \%)\end{array}$ & $\begin{array}{c}\text { Lower } \\
(5 \%)\end{array}$ & $\begin{array}{l}\text { Upper } \\
(95 \%)\end{array}$ & Mean \\
\hline \multicolumn{2}{|c|}{2015 Update } & & & & & $1.51 \mathrm{E}-03$ & 2.99E-03 & 2.20E-03 \\
\hline 1998 & 0 & 2,117 & -- & -- & -- & $9.00 \mathrm{E}-07$ & 1.79E-03 & 2.29E-04 \\
\hline 1999 & 1 & 1,092 & -- & -- & -- & $1.52 \mathrm{E}-04$ & 4.77E-03 & $1.29 \mathrm{E}-03$ \\
\hline 2000 & 3 & 506 & -- & -- & -- & 1.89E-03 & 1.47E-02 & 6.09E-03 \\
\hline 2001 & 1 & 655 & -- & -- & -- & 2.43E-04 & 7.65E-03 & 2.07E-03 \\
\hline 2002 & 0 & 1,154 & -- & -- & -- & $1.61 \mathrm{E}-06$ & $3.20 \mathrm{E}-03$ & 4.09E-04 \\
\hline 2003 & 1 & 1,498 & -- & -- & -- & 1.12E-04 & 3.53E-03 & 9.57E-04 \\
\hline 2004 & 4 & 368 & -- & -- & -- & 3.80E-03 & 2.25E-02 & 1.03E-02 \\
\hline 2005 & 3 & 243 & -- & -- & -- & 3.48E-03 & 2.72E-02 & 1.12E-02 \\
\hline 2006 & 0 & 242 & -- & -- & -- & 6.32E-06 & 1.26E-02 & 1.61E-03 \\
\hline 2007 & 1 & 256 & -- & -- & -- & 5.42E-04 & 1.70E-02 & 4.62E-03 \\
\hline 2008 & 2 & 282 & -- & -- & -- & $1.64 \mathrm{E}-03$ & 2.01E-02 & 7.14E-03 \\
\hline 2009 & 0 & 332 & 4.30E-03 & 1.76E-03 & $1.05 E-02$ & 4.90E-06 & $9.75 \mathrm{E}-03$ & $1.25 \mathrm{E}-03$ \\
\hline 2010 & 1 & 321 & $4.68 \mathrm{E}-03$ & 2.19E-03 & 1.00E-02 & $4.52 \mathrm{E}-04$ & 1.42E-02 & 3.85E-03 \\
\hline 2011 & 4 & 419 & 5.09E-03 & 2.69E-03 & $9.65 E-03$ & 3.41E-03 & 2.02E-02 & 9.23E-03 \\
\hline 2012 & 4 & 301 & 5.54E-03 & $3.24 \mathrm{E}-03$ & $9.50 \mathrm{E}-03$ & $4.50 \mathrm{E}-03$ & 2.66E-02 & 1.22E-02 \\
\hline 2013 & 3 & 331 & 6.04E-03 & 3.76E-03 & 9.68E-03 & 2.71E-03 & 2.12E-02 & 8.77E-03 \\
\hline 2014 & 3 & 317 & $6.57 \mathrm{E}-03$ & 4.16E-03 & 1.04E-02 & $2.81 \mathrm{E}-03$ & 2.20E-02 & $9.08 \mathrm{E}-03$ \\
\hline 2015 & 2 & 286 & 7.16E-03 & 4.36E-03 & 1.17E-02 & 1.62E-03 & 1.98E-02 & 7.06E-03 \\
\hline 2016 & 2 & 368 & 7.79E-03 & 4.37E-03 & 1.39E-02 & 1.31E-03 & 1.61E-02 & 5.73E-03 \\
\hline 2017 & 2 & 326 & 8.49E-03 & 4.26E-03 & 1.69E-02 & $1.45 \mathrm{E}-03$ & 1.78E-02 & 6.33E-03 \\
\hline 2018 & 2 & 222 & $9.24 \mathrm{E}-03$ & 4.08E-03 & 2.09E-02 & 1.97E-03 & 2.42E-02 & 8.62E-03 \\
\hline Total & 39 & 11,636 & & & & & & \\
\hline
\end{tabular}


Table 12. Plot data for Figure 4, failure probability estimate trend for normally running TDP FTS.

\begin{tabular}{|c|c|c|c|c|c|c|c|c|}
\hline \multirow[b]{2}{*}{ Year } & \multirow[b]{2}{*}{ Failures } & \multirow[b]{2}{*}{ Demands } & \multicolumn{3}{|c|}{ Regression Curve Data Points } & \multicolumn{3}{|c|}{ Yearly Estimate Data Points } \\
\hline & & & Mean & $\begin{array}{c}\text { Lower } \\
(5 \%)\end{array}$ & $\begin{array}{l}\text { Upper } \\
(95 \%)\end{array}$ & $\begin{array}{c}\text { Lower } \\
(5 \%)\end{array}$ & $\begin{array}{l}\text { Upper } \\
(95 \%)\end{array}$ & Mean \\
\hline \multicolumn{2}{|c|}{2015 Update } & & & & & $4.01 \mathrm{E}-04$ & 2.78E-02 & 9.16E-03 \\
\hline 1998 & 2 & 79 & -- & -- & -- & 3.51E-03 & 4.24E-02 & $1.53 \mathrm{E}-02$ \\
\hline 1999 & 2 & 79 & -- & -- & -- & 3.51E-03 & 4.24E-02 & $1.53 \mathrm{E}-02$ \\
\hline 2000 & 0 & 79 & -- & -- & -- & $1.20 \mathrm{E}-05$ & 2.36E-02 & 3.06E-03 \\
\hline 2001 & 1 & 78 & -- & -- & -- & 1.08E-03 & 3.35E-02 & $9.20 \mathrm{E}-03$ \\
\hline 2002 & 0 & 78 & -- & -- & -- & $1.20 \mathrm{E}-05$ & 2.37E-02 & 3.07E-03 \\
\hline 2003 & 0 & 78 & -- & -- & -- & 1.20E-05 & 2.37E-02 & 3.07E-03 \\
\hline 2004 & 0 & 78 & -- & -- & -- & 1.20E-05 & 2.37E-02 & 3.06E-03 \\
\hline 2005 & 3 & 78 & -- & -- & -- & 6.69E-03 & 5.12E-02 & $2.15 \mathrm{E}-02$ \\
\hline 2006 & 1 & 78 & -- & -- & -- & $1.08 \mathrm{E}-03$ & 3.35E-02 & $9.20 \mathrm{E}-03$ \\
\hline 2007 & 0 & 78 & -- & -- & -- & 1.20E-05 & 2.37E-02 & 3.07E-03 \\
\hline 2008 & 0 & 78 & -- & -- & -- & 1.21E-05 & 2.37E-02 & 3.07E-03 \\
\hline 2009 & 1 & 78 & 6.13E-03 & 2.62E-03 & $1.43 \mathrm{E}-02$ & $1.08 \mathrm{E}-03$ & 3.37E-02 & $9.24 \mathrm{E}-03$ \\
\hline 2010 & 0 & 76 & 5.81E-03 & $2.82 \mathrm{E}-03$ & 1.19E-02 & $1.22 \mathrm{E}-05$ & 2.40E-02 & $3.10 \mathrm{E}-03$ \\
\hline 2011 & 0 & 76 & 5.51E-03 & 3.00E-03 & 1.01E-02 & 1.22E-05 & 2.40E-02 & $3.11 \mathrm{E}-03$ \\
\hline 2012 & 1 & 76 & $5.22 \mathrm{E}-03$ & 3.11E-03 & 8.74E-03 & 1.09E-03 & 3.40E-02 & $9.32 \mathrm{E}-03$ \\
\hline 2013 & 1 & 76 & 4.95E-03 & 3.12E-03 & 7.85E-03 & 1.09E-03 & 3.40E-02 & $9.32 \mathrm{E}-03$ \\
\hline 2014 & 0 & 76 & 4.69E-03 & 2.96E-03 & 7.42E-03 & 1.22E-05 & 2.40E-02 & 3.11E-03 \\
\hline 2015 & 0 & 76 & 4.45E-03 & 2.68E-03 & 7.38E-03 & 1.22E-05 & 2.40E-02 & $3.11 \mathrm{E}-03$ \\
\hline 2016 & 1 & 76 & 4.22E-03 & 2.33E-03 & 7.63E-03 & 1.09E-03 & 3.40E-02 & $9.32 \mathrm{E}-03$ \\
\hline 2017 & 0 & 76 & 4.00E-03 & 1.97E-03 & 8.09E-03 & 1.22E-05 & 2.40E-02 & $3.10 \mathrm{E}-03$ \\
\hline 2018 & 0 & 76 & 3.79E-03 & $1.64 \mathrm{E}-03$ & 8.71E-03 & 1.22E-05 & 2.40E-02 & $3.11 \mathrm{E}-03$ \\
\hline Total & 13 & 1,624 & & & & & & \\
\hline
\end{tabular}


Table 13. Plot data for Figure 5, failure rate estimate trend for normally running TDP FTR.

\begin{tabular}{|c|c|c|c|c|c|c|c|c|}
\hline \multirow[b]{2}{*}{ Year } & \multirow[b]{2}{*}{ Failures } & \multirow[b]{2}{*}{ Hours } & \multicolumn{3}{|c|}{ Regression Curve Data Points } & \multicolumn{3}{|c|}{ Yearly Estimate Data Points } \\
\hline & & & Mean & $\begin{array}{c}\text { Lower } \\
(5 \%)\end{array}$ & $\begin{array}{l}\text { Upper } \\
(95 \%)\end{array}$ & $\begin{array}{c}\text { Lower } \\
\text { (5\%) }\end{array}$ & $\begin{array}{l}\text { Upper } \\
(95 \%)\end{array}$ & Mean \\
\hline \multicolumn{2}{|c|}{2015 Update } & & & & & $1.52 \mathrm{E}-06$ & 2.67E-05 & 1.07E-05 \\
\hline 1998 & 1 & 335,022 & -- & -- & -- & 4.60E-07 & $1.45 \mathrm{E}-05$ & 3.92E-06 \\
\hline 1999 & 6 & 335,022 & -- & -- & -- & 7.70E-06 & 3.27E-05 & 1.70E-05 \\
\hline 2000 & 2 & 335,022 & -- & -- & -- & $1.50 \mathrm{E}-06$ & 1.84E-05 & $6.54 \mathrm{E}-06$ \\
\hline 2001 & 3 & 335,432 & -- & -- & -- & 2.83E-06 & 2.21E-05 & $9.14 \mathrm{E}-06$ \\
\hline 2002 & 3 & 335,387 & -- & -- & -- & 2.83E-06 & 2.21E-05 & 9.14E-06 \\
\hline 2003 & 6 & 335,371 & -- & -- & -- & 7.69E-06 & 3.26E-05 & 1.70E-05 \\
\hline 2004 & 3 & 335,356 & -- & -- & -- & 2.83E-06 & 2.21E-05 & $9.14 \mathrm{E}-06$ \\
\hline 2005 & 6 & 335,417 & -- & -- & -- & 7.69E-06 & 3.26E-05 & 1.70E-05 \\
\hline 2006 & 3 & 335,463 & -- & -- & -- & 2.83E-06 & 2.21E-05 & $9.14 \mathrm{E}-06$ \\
\hline 2007 & 3 & 335,326 & -- & -- & -- & 2.83E-06 & 2.21E-05 & $9.14 \mathrm{E}-06$ \\
\hline 2008 & 3 & 335,387 & -- & -- & -- & 2.83E-06 & 2.21E-05 & $9.14 \mathrm{E}-06$ \\
\hline 2009 & 3 & 333,274 & 1.22E-05 & 7.21E-06 & 2.07E-05 & 2.85E-06 & 2.22E-05 & $9.19 \mathrm{E}-06$ \\
\hline 2010 & 6 & 327,318 & 1.16E-05 & 7.43E-06 & 1.81E-05 & 7.86E-06 & 3.33E-05 & $1.73 \mathrm{E}-05$ \\
\hline 2011 & 2 & 327,181 & 1.10E-05 & 7.58E-06 & 1.60E-05 & 1.53E-06 & $1.88 \mathrm{E}-05$ & 6.67E-06 \\
\hline 2012 & 6 & 327,166 & 1.05E-05 & 7.59E-06 & 1.45E-05 & 7.86E-06 & 3.34E-05 & $1.73 \mathrm{E}-05$ \\
\hline 2013 & 4 & 327,089 & 9.95E-06 & 7.38E-06 & 1.34E-05 & 4.44E-06 & 2.63E-05 & $1.20 \mathrm{E}-05$ \\
\hline 2014 & 2 & 327,257 & 9.45E-06 & 6.93E-06 & 1.29E-05 & $1.53 \mathrm{E}-06$ & $1.88 \mathrm{E}-05$ & 6.67E-06 \\
\hline 2015 & 4 & 327,196 & 8.98E-06 & 6.31E-06 & $1.28 \mathrm{E}-05$ & 4.44E-06 & 2.63E-05 & 1.20E-05 \\
\hline 2016 & 2 & 327,196 & 8.53E-06 & 5.62E-06 & 1.30E-05 & $1.53 \mathrm{E}-06$ & 1.88E-05 & 6.67E-06 \\
\hline 2017 & 3 & 327,074 & 8.10E-06 & 4.93E-06 & 1.33E-05 & 2.89E-06 & 2.26E-05 & $9.34 \mathrm{E}-06$ \\
\hline 2018 & 2 & 327,272 & 7.70E-06 & 4.30E-06 & 1.38E-05 & 1.53E-06 & 1.88E-05 & 6.67E-06 \\
\hline Total & 73 & $6,966,227$ & & & & & & \\
\hline
\end{tabular}


Table 14. Plot data for Figure 6, pooled standby TDP UA trend.

\begin{tabular}{|c|c|c|c|c|c|c|c|c|}
\hline \multirow[b]{2}{*}{ Year } & \multirow[b]{2}{*}{$\begin{array}{c}\text { UA } \\
\text { Hours }\end{array}$} & \multirow[b]{2}{*}{$\begin{array}{l}\text { Critical } \\
\text { Hours }\end{array}$} & \multicolumn{3}{|c|}{ Regression Curve Data Points } & \multicolumn{3}{|c|}{ Yearly Estimate Data Points } \\
\hline & & & Mean & $\begin{array}{l}\text { Lower } \\
(5 \%)\end{array}$ & $\begin{array}{l}\text { Upper } \\
(95 \%)\end{array}$ & $\begin{array}{c}\text { Lower } \\
(5 \%)\end{array}$ & $\begin{array}{l}\text { Upper } \\
(95 \%)\end{array}$ & Mean \\
\hline \multicolumn{2}{|c|}{2015 Update } & & & & & 2.92E-04 & $1.41 \mathrm{E}-02$ & $7.25 \mathrm{E}-03$ \\
\hline 1998 & $8,302.7$ & $866,019.5$ & -- & -- & -- & 1.06E-04 & $3.54 \mathrm{E}-02$ & 9.96E-03 \\
\hline 1999 & $8,368.3$ & $932,826.8$ & -- & -- & -- & $6.85 E-04$ & 2.55E-02 & 9.06E-03 \\
\hline 2000 & $7,171.6$ & $953,904.4$ & -- & -- & -- & 8.55E-04 & 2.05E-02 & 7.77E-03 \\
\hline 2001 & $7,895.0$ & $960,556.3$ & -- & -- & -- & 3.67E-04 & $2.56 \mathrm{E}-02$ & 8.39E-03 \\
\hline 2002 & $7,870.1$ & $962,744.5$ & -- & -- & -- & 5.37E-04 & 2.36E-02 & 8.19E-03 \\
\hline 2003 & $8,371.1$ & $939,190.1$ & -- & -- & -- & 8.62E-04 & 2.42E-02 & 8.97E-03 \\
\hline 2004 & $7,232.5$ & $972,700.8$ & -- & -- & -- & 5.32E-04 & 2.17E-02 & 7.62E-03 \\
\hline 2005 & $6,151.5$ & $962,532.6$ & -- & -- & -- & 8.19E-04 & 1.66E-02 & $6.50 \mathrm{E}-03$ \\
\hline 2006 & $6,545.3$ & $965,328.7$ & -- & -- & -- & 9.07E-04 & 1.71E-02 & $6.78 \mathrm{E}-03$ \\
\hline 2007 & $7,837.8$ & $976,679.0$ & -- & -- & -- & 4.91E-05 & 3.07E-02 & 8.26E-03 \\
\hline 2008 & $7,332.2$ & $971,611.9$ & -- & -- & -- & 5.97E-05 & 2.74E-02 & 7.53E-03 \\
\hline 2009 & $7,832.5$ & $954,932.0$ & 8.80E-03 & 7.74E-03 & 9.86E-03 & 2.41E-05 & 3.26E-02 & 8.33E-03 \\
\hline 2010 & $8,166.7$ & $964,326.7$ & 8.55E-03 & 7.73E-03 & $9.38 \mathrm{E}-03$ & 8.02E-04 & 2.29E-02 & 8.46E-03 \\
\hline 2011 & $8,040.6$ & $937,925.5$ & 8.31E-03 & 7.72E-03 & 8.90E-03 & 5.32E-04 & 2.58E-02 & 8.84E-03 \\
\hline 2012 & $7,351.7$ & $921,716.4$ & 8.07E-03 & 7.72E-03 & 8.42E-03 & 4.34E-04 & 2.26E-02 & 7.68E-03 \\
\hline 2013 & $8,161.4$ & $927,539.5$ & 7.83E-03 & 7.71E-03 & 7.94E-03 & 1.85E-08 & 4.32E-02 & 8.48E-03 \\
\hline 2014 & $7,050.1$ & $938,778.0$ & 7.58E-03 & 7.46E-03 & 7.70E-03 & 4.90E-04 & 2.20E-02 & 7.61E-03 \\
\hline 2015 & $6,364.8$ & $924,171.6$ & 7.34E-03 & 6.99E-03 & 7.69E-03 & 7.69E-04 & 1.80E-02 & $6.88 \mathrm{E}-03$ \\
\hline 2016 & $7,131.4$ & $932,914.0$ & 7.10E-03 & 6.51E-03 & 7.68E-03 & 6.79E-04 & 2.10E-02 & 7.66E-03 \\
\hline 2017 & $6,744.6$ & $926,540.3$ & 6.85E-03 & 6.03E-03 & 7.68E-03 & 4.12E-04 & 2.15E-02 & 7.30E-03 \\
\hline 2018 & $5,270.6$ & $920,288.2$ & 6.61E-03 & 5.55E-03 & 7.67E-03 & 2.73E-04 & 1.76E-02 & 5.80E-03 \\
\hline Total & $155,192.6$ & $19,813,226.7$ & & & & & & \\
\hline
\end{tabular}


Table 15. Plot data for Figure 7, standby TDP unreliability trend (8-hour mission).

\begin{tabular}{|c|c|c|c|c|c|c|}
\hline \multirow[b]{2}{*}{ Year } & \multicolumn{3}{|c|}{ Regression Curve Data Points } & \multicolumn{3}{|c|}{ Yearly Estimate Data Points } \\
\hline & Mean & Lower (5\%) & Upper (95\%) & Lower (5\%) & Upper (95\%) & Mean \\
\hline 1998 & -- & -- & -- & 3.10E-03 & 4.01E-02 & 1.47E-02 \\
\hline 1999 & -- & -- & -- & 1.19E-02 & $5.49 \mathrm{E}-02$ & 2.76E-02 \\
\hline 2000 & -- & -- & -- & 3.13E-02 & 9.34E-02 & 5.90E-02 \\
\hline 2001 & -- & -- & -- & 1.19E-02 & $5.28 \mathrm{E}-02$ & 2.86E-02 \\
\hline 2002 & -- & -- & -- & $7.58 \mathrm{E}-03$ & 3.05E-02 & 1.66E-02 \\
\hline 2003 & -- & -- & -- & $1.32 \mathrm{E}-02$ & 3.92E-02 & 2.42E-02 \\
\hline 2004 & -- & -- & -- & 3.49E-02 & $1.24 \mathrm{E}-01$ & 7.35E-02 \\
\hline 2005 & -- & -- & -- & 3.16E-02 & 1.37E-01 & 7.61E-02 \\
\hline 2006 & -- & -- & -- & 8.70E-03 & 5.26E-02 & 2.39E-02 \\
\hline 2007 & -- & -- & -- & 1.67E-02 & 8.43E-02 & 4.28E-02 \\
\hline 2008 & -- & -- & -- & 2.61E-02 & 1.12E-01 & 5.92E-02 \\
\hline 2009 & 4.41E-02 & 2.99E-02 & 6.52E-02 & 1.22E-02 & 5.12E-02 & 2.65E-02 \\
\hline 2010 & 4.58E-02 & 3.29E-02 & 6.37E-02 & $1.42 \mathrm{E}-02$ & 7.37E-02 & 3.77E-02 \\
\hline 2011 & 4.74E-02 & 3.59E-02 & 6.26E-02 & 3.36E-02 & 1.10E-01 & 6.71E-02 \\
\hline 2012 & 4.92E-02 & 3.88E-02 & 6.23E-02 & 3.46E-02 & $1.33 \mathrm{E}-01$ & 7.79E-02 \\
\hline 2013 & 5.10E-02 & 4.12E-02 & 6.31E-02 & 2.68E-02 & $1.08 \mathrm{E}-01$ & 5.99E-02 \\
\hline 2014 & 5.28E-02 & 4.27E-02 & 6.54E-02 & 2.92E-02 & 1.12E-01 & 6.49E-02 \\
\hline 2015 & $5.48 \mathrm{E}-02$ & 4.32E-02 & 6.94E-02 & 1.95E-02 & $9.74 \mathrm{E}-02$ & 5.11E-02 \\
\hline 2016 & 5.68E-02 & 4.30E-02 & 7.49E-02 & 2.05E-02 & 9.46E-02 & 4.94E-02 \\
\hline 2017 & 5.88E-02 & 4.23E-02 & 8.19E-02 & $1.74 \mathrm{E}-02$ & 9.39E-02 & 4.87E-02 \\
\hline 2018 & 6.10E-02 & 4.13E-02 & 9.00E-02 & 2.00E-02 & 1.18E-01 & 5.67E-02 \\
\hline
\end{tabular}


Table 16. Plot data for Figure 8, normally running TDP unreliability trend (8-hour mission).

\begin{tabular}{|c|c|c|c|c|c|c|}
\hline \multirow[b]{2}{*}{ Year } & \multicolumn{3}{|c|}{ Regression Curve Data Points } & \multicolumn{3}{|c|}{ Yearly Estimate Data Points } \\
\hline & Mean & Lower $(5 \%)$ & Upper (95\%) & $\begin{array}{c}\text { Lower } \\
(5 \%)\end{array}$ & $\begin{array}{l}\text { Upper } \\
(95 \%)\end{array}$ & Mean \\
\hline 1998 & -- & -- & -- & 3.83E-03 & 3.85E-02 & $1.75 \mathrm{E}-02$ \\
\hline 1999 & -- & -- & -- & 4.88E-03 & 4.26E-02 & $1.84 \mathrm{E}-02$ \\
\hline 2000 & -- & -- & -- & $1.45 \mathrm{E}-04$ & $1.51 \mathrm{E}-02$ & $3.91 \mathrm{E}-03$ \\
\hline 2001 & -- & -- & -- & $1.58 \mathrm{E}-03$ & 2.70E-02 & 1.10E-02 \\
\hline 2002 & -- & -- & -- & 1.99E-04 & 1.34E-02 & 3.86E-03 \\
\hline 2003 & -- & -- & -- & 3.67E-04 & $1.51 \mathrm{E}-02$ & 4.07E-03 \\
\hline 2004 & -- & -- & -- & 2.08E-04 & $1.41 \mathrm{E}-02$ & 3.97E-03 \\
\hline 2005 & -- & -- & -- & 7.92E-03 & 4.89E-02 & 2.55E-02 \\
\hline 2006 & -- & -- & -- & 1.40E-03 & 2.95E-02 & 1.13E-02 \\
\hline 2007 & -- & -- & -- & 1.94E-04 & 1.36E-02 & $3.75 \mathrm{E}-03$ \\
\hline 2008 & -- & -- & -- & 2.05E-04 & 1.51E-02 & 4.16E-03 \\
\hline 2009 & 7.61E-03 & 3.82E-03 & 1.52E-02 & $1.56 \mathrm{E}-03$ & 2.91E-02 & 1.16E-02 \\
\hline 2010 & 7.20E-03 & 4.01E-03 & $1.29 \mathrm{E}-02$ & 3.69E-04 & 1.47E-02 & $4.20 \mathrm{E}-03$ \\
\hline 2011 & 6.81E-03 & 4.16E-03 & 1.11E-02 & 1.35E-04 & 1.53E-02 & $3.75 \mathrm{E}-03$ \\
\hline 2012 & 6.44E-03 & 4.24E-03 & 9.79E-03 & 1.63E-03 & 2.83E-02 & 1.13E-02 \\
\hline 2013 & 6.09E-03 & 4.18E-03 & 8.88E-03 & 1.59E-03 & 2.73E-02 & 1.05E-02 \\
\hline 2014 & 5.76E-03 & 3.95E-03 & 8.40E-03 & 1.51E-04 & 1.26E-02 & 3.64E-03 \\
\hline 2015 & 5.45E-03 & $3.58 \mathrm{E}-03$ & $8.28 \mathrm{E}-03$ & 2.61E-04 & 1.51E-02 & $4.02 \mathrm{E}-03$ \\
\hline 2016 & 5.15E-03 & 3.15E-03 & 8.43E-03 & 1.38E-03 & 2.86E-02 & 1.10E-02 \\
\hline 2017 & $4.88 E-03$ & 2.72E-03 & 8.75E-03 & 1.92E-04 & 1.57E-02 & 3.99E-03 \\
\hline 2018 & 4.61E-03 & 2.31E-03 & 9.19E-03 & 1.44E-04 & 1.49E-02 & $3.81 \mathrm{E}-03$ \\
\hline
\end{tabular}


Table 17. Plot data for Figure 9, frequency of start demands (demands per reactor year) trend for standby TDPs.

\begin{tabular}{|c|c|c|c|c|c|c|c|c|}
\hline \multirow[b]{2}{*}{ Year } & \multirow[b]{2}{*}{ Demands } & \multirow[b]{2}{*}{$\begin{array}{l}\text { Reactor } \\
\text { Years }\end{array}$} & \multicolumn{3}{|c|}{ Regression Curve Data Points } & \multicolumn{3}{|c|}{ Yearly Estimate Data Points } \\
\hline & & & Mean & $\begin{array}{c}\text { Lower } \\
(5 \%)\end{array}$ & $\begin{array}{l}\text { Upper } \\
(95 \%)\end{array}$ & $\begin{array}{c}\text { Lower } \\
\text { (5\%) }\end{array}$ & $\begin{array}{l}\text { Upper } \\
\text { (95\%) }\end{array}$ & Mean \\
\hline 1998 & 1,512 & 97.0 & -- & -- & -- & $1.49 \mathrm{E}+01$ & $1.63 E+01$ & $1.56 \mathrm{E}+01$ \\
\hline 1999 & 1,496 & 97.0 & -- & -- & -- & $1.48 \mathrm{E}+01$ & $1.61 \mathrm{E}+01$ & $1.54 \mathrm{E}+01$ \\
\hline 2000 & 1,438 & 97.3 & -- & -- & -- & $1.42 \mathrm{E}+01$ & $1.54 \mathrm{E}+01$ & $1.48 E+01$ \\
\hline 2001 & 1,430 & 97.0 & -- & -- & -- & $1.41 \mathrm{E}+01$ & $1.54 \mathrm{E}+01$ & $1.47 E+01$ \\
\hline 2002 & 1,395 & 97.0 & -- & -- & -- & $1.38 \mathrm{E}+01$ & $1.50 \mathrm{E}+01$ & $1.44 \mathrm{E}+01$ \\
\hline 2003 & 1,518 & 97.0 & -- & -- & -- & $1.50 \mathrm{E}+01$ & $1.63 \mathrm{E}+01$ & $1.56 \mathrm{E}+01$ \\
\hline 2004 & 1,447 & 97.3 & -- & -- & -- & $1.42 \mathrm{E}+01$ & $1.55 \mathrm{E}+01$ & $1.49 E+01$ \\
\hline 2005 & 1,425 & 97.0 & -- & -- & -- & $1.41 \mathrm{E}+01$ & $1.54 \mathrm{E}+01$ & $1.47 E+01$ \\
\hline 2006 & 1,462 & 97.0 & -- & -- & -- & $1.44 \mathrm{E}+01$ & $1.57 \mathrm{E}+01$ & $1.51 \mathrm{E}+01$ \\
\hline 2007 & 1,381 & 97.6 & -- & -- & -- & $1.35 \mathrm{E}+01$ & $1.48 \mathrm{E}+01$ & $1.41 E+01$ \\
\hline 2008 & 1,446 & 98.3 & -- & -- & -- & $1.41 \mathrm{E}+01$ & $1.54 \mathrm{E}+01$ & $1.47 E+01$ \\
\hline 2009 & 1,543 & 98.0 & $1.59 \mathrm{E}+01$ & $1.55 \mathrm{E}+01$ & $1.64 \mathrm{E}+01$ & $1.51 \mathrm{E}+01$ & $1.64 \mathrm{E}+01$ & $1.57 E+01$ \\
\hline 2010 & 1,574 & 98.0 & $1.59 \mathrm{E}+01$ & $1.55 \mathrm{E}+01$ & $1.63 E+01$ & $1.54 \mathrm{E}+01$ & $1.67 E+01$ & $1.61 \mathrm{E}+01$ \\
\hline 2011 & 1,572 & 98.0 & $1.59 \mathrm{E}+01$ & $1.56 \mathrm{E}+01$ & $1.62 \mathrm{E}+01$ & $1.54 \mathrm{E}+01$ & $1.67 \mathrm{E}+01$ & $1.60 E+01$ \\
\hline 2012 & 1,501 & 98.3 & $1.59 \mathrm{E}+01$ & $1.56 \mathrm{E}+01$ & $1.61 \mathrm{E}+01$ & $1.46 \mathrm{E}+01$ & $1.59 \mathrm{E}+01$ & $1.53 E+01$ \\
\hline 2013 & 1,538 & 95.6 & $1.58 \mathrm{E}+01$ & $1.56 \mathrm{E}+01$ & $1.61 \mathrm{E}+01$ & $1.54 \mathrm{E}+01$ & $1.68 \mathrm{E}+01$ & $1.61 E+01$ \\
\hline 2014 & 1,488 & 94.0 & $1.58 \mathrm{E}+01$ & $1.56 \mathrm{E}+01$ & $1.61 \mathrm{E}+01$ & $1.52 \mathrm{E}+01$ & $1.65 \mathrm{E}+01$ & $1.58 E+01$ \\
\hline 2015 & 1,510 & 93.0 & $1.58 \mathrm{E}+01$ & $1.55 \mathrm{E}+01$ & $1.61 \mathrm{E}+01$ & $1.56 \mathrm{E}+01$ & $1.69 \mathrm{E}+01$ & $1.62 E+01$ \\
\hline 2016 & 1,485 & 93.0 & $1.58 \mathrm{E}+01$ & $1.55 \mathrm{E}+01$ & $1.61 \mathrm{E}+01$ & $1.53 \mathrm{E}+01$ & $1.67 \mathrm{E}+01$ & $1.60 E+01$ \\
\hline 2017 & 1,449 & 92.0 & $1.58 \mathrm{E}+01$ & $1.54 \mathrm{E}+01$ & $1.62 \mathrm{E}+01$ & $1.51 \mathrm{E}+01$ & $1.64 \mathrm{E}+01$ & $1.57 E+01$ \\
\hline 2018 & 1,420 & 92.0 & $1.58 \mathrm{E}+01$ & $1.53 E+01$ & $1.62 E+01$ & $1.48 \mathrm{E}+01$ & $1.61 \mathrm{E}+01$ & $1.54 \mathrm{E}+01$ \\
\hline Total & 31,031 & $2,021.3$ & & & & & & \\
\hline
\end{tabular}


Table 18. Plot data for Figure 10, frequency of run $\leq 1$ H hours (hours per reactor year) trend for standby TDPs.

\begin{tabular}{ccccccccc}
\hline & & & \multicolumn{3}{c}{ Regression Curve Data Points } & \multicolumn{2}{c}{ Yearly Estimate Data Points } \\
\cline { 6 - 9 } Year & Hours & $\begin{array}{c}\text { Reactor } \\
\text { Years }\end{array}$ & Mean & Lower & Upper & Lower & Upper & Mean \\
\hline 1998 & 1,512 & 97.0 & -- & -- & -- & $1.49 \mathrm{E}+01$ & $1.63 \mathrm{E}+01$ & $1.56 \mathrm{E}+01$ \\
\hline 1999 & 1,496 & 97.0 & -- & -- & -- & $1.48 \mathrm{E}+01$ & $1.61 \mathrm{E}+01$ & $1.54 \mathrm{E}+01$ \\
\hline 2000 & 1,438 & 97.3 & -- & -- & -- & $1.42 \mathrm{E}+01$ & $1.54 \mathrm{E}+01$ & $1.48 \mathrm{E}+01$ \\
\hline 2001 & 1,430 & 97.0 & -- & -- & -- & $1.41 \mathrm{E}+01$ & $1.54 \mathrm{E}+01$ & $1.47 \mathrm{E}+01$ \\
\hline 2002 & 1,395 & 97.0 & -- & -- & -- & $1.38 \mathrm{E}+01$ & $1.50 \mathrm{E}+01$ & $1.44 \mathrm{E}+01$ \\
\hline 2003 & 1,518 & 97.0 & -- & -- & -- & $1.50 \mathrm{E}+01$ & $1.63 \mathrm{E}+01$ & $1.56 \mathrm{E}+01$ \\
\hline 2004 & 1,447 & 97.3 & -- & -- & -- & $1.42 \mathrm{E}+01$ & $1.55 \mathrm{E}+01$ & $1.49 \mathrm{E}+01$ \\
\hline 2005 & 1,425 & 97.0 & -- & -- & -- & $1.41 \mathrm{E}+01$ & $1.54 \mathrm{E}+01$ & $1.47 \mathrm{E}+01$ \\
\hline 2006 & 1,462 & 97.0 & -- & -- & -- & $1.44 \mathrm{E}+01$ & $1.57 \mathrm{E}+01$ & $1.51 \mathrm{E}+01$ \\
\hline 2007 & 1,381 & 97.6 & -- & -- & -- & $1.35 \mathrm{E}+01$ & $1.48 \mathrm{E}+01$ & $1.41 \mathrm{E}+01$ \\
\hline 2008 & 1,446 & 98.3 & -- & -- & -- & $1.41 \mathrm{E}+01$ & $1.54 \mathrm{E}+01$ & $1.47 \mathrm{E}+01$ \\
\hline 2009 & 1,543 & 98.0 & $1.59 \mathrm{E}+01$ & $1.55 \mathrm{E}+01$ & $1.64 \mathrm{E}+01$ & $1.51 \mathrm{E}+01$ & $1.64 \mathrm{E}+01$ & $1.57 \mathrm{E}+01$ \\
\hline 2010 & 1,574 & 98.0 & $1.59 \mathrm{E}+01$ & $1.55 \mathrm{E}+01$ & $1.63 \mathrm{E}+01$ & $1.54 \mathrm{E}+01$ & $1.67 \mathrm{E}+01$ & $1.61 \mathrm{E}+01$ \\
\hline 2011 & 1,572 & 98.0 & $1.59 \mathrm{E}+01$ & $1.56 \mathrm{E}+01$ & $1.62 \mathrm{E}+01$ & $1.54 \mathrm{E}+01$ & $1.67 \mathrm{E}+01$ & $1.60 \mathrm{E}+01$ \\
\hline 2012 & 1,501 & 98.3 & $1.59 \mathrm{E}+01$ & $1.56 \mathrm{E}+01$ & $1.61 \mathrm{E}+01$ & $1.46 \mathrm{E}+01$ & $1.59 \mathrm{E}+01$ & $1.53 \mathrm{E}+01$ \\
\hline 2013 & 1,538 & 95.6 & $1.58 \mathrm{E}+01$ & $1.56 \mathrm{E}+01$ & $1.61 \mathrm{E}+01$ & $1.54 \mathrm{E}+01$ & $1.68 \mathrm{E}+01$ & $1.61 \mathrm{E}+01$ \\
\hline 2014 & 1,488 & 94.0 & $1.58 \mathrm{E}+01$ & $1.56 \mathrm{E}+01$ & $1.61 \mathrm{E}+01$ & $1.52 \mathrm{E}+01$ & $1.65 \mathrm{E}+01$ & $1.58 \mathrm{E}+01$ \\
\hline 2015 & 1,510 & 93.0 & $1.58 \mathrm{E}+01$ & $1.55 \mathrm{E}+01$ & $1.61 \mathrm{E}+01$ & $1.56 \mathrm{E}+01$ & $1.69 \mathrm{E}+01$ & $1.62 \mathrm{E}+01$ \\
\hline 2016 & 1,485 & 93.0 & $1.58 \mathrm{E}+01$ & $1.55 \mathrm{E}+01$ & $1.61 \mathrm{E}+01$ & $1.53 \mathrm{E}+01$ & $1.67 \mathrm{E}+01$ & $1.60 \mathrm{E}+01$ \\
\hline 2017 & 1,449 & 92.0 & $1.58 \mathrm{E}+01$ & $1.54 \mathrm{E}+01$ & $1.62 \mathrm{E}+01$ & $1.51 \mathrm{E}+01$ & $1.64 \mathrm{E}+01$ & $1.57 \mathrm{E}+01$ \\
\hline 2018 & 1,420 & 92.0 & $1.58 \mathrm{E}+01$ & $1.53 \mathrm{E}+01$ & $1.62 \mathrm{E}+01$ & $1.48 \mathrm{E}+01$ & $1.61 \mathrm{E}+01$ & $1.54 \mathrm{E}+01$ \\
\hline Total & 31,031 & $2,021.3$ & & & & & & \\
\hline & & & & & & & & \\
\hline
\end{tabular}


Table 19. Plot data for Figure 11, frequency of run $>1$ H hours (hours per reactor year) trend for standby TDPs.

\begin{tabular}{ccccccccc}
\hline & & & \multicolumn{2}{c}{ Regression Curve Data Points } & \multicolumn{2}{c}{ Yearly Estimate Data Points } \\
\cline { 6 - 9 } Year & $\begin{array}{c}\text { Run } \\
\text { Hours }\end{array}$ & $\begin{array}{c}\text { Reactor } \\
\text { Years }\end{array}$ & Mean & $\begin{array}{c}\text { Lower } \\
\mathbf{( 5 \% )}\end{array}$ & $\begin{array}{c}\text { Upper } \\
\mathbf{( 9 5 \% )}\end{array}$ & $\begin{array}{c}\text { Lower } \\
\mathbf{( 5 \% )}\end{array}$ & $\begin{array}{c}\text { Upper } \\
\mathbf{( 9 5 \% )}\end{array}$ & Mean \\
\hline 1998 & 2,117 & 97.0 & -- & -- & -- & $2.10 \mathrm{E}+01$ & $2.26 \mathrm{E}+01$ & $2.18 \mathrm{E}+01$ \\
\hline 1999 & 1,092 & 97.0 & -- & -- & -- & $1.07 \mathrm{E}+01$ & $1.18 \mathrm{E}+01$ & $1.13 \mathrm{E}+01$ \\
\hline 2000 & 506 & 97.3 & -- & -- & -- & $4.83 \mathrm{E}+00$ & $5.60 \mathrm{E}+00$ & $5.20 \mathrm{E}+00$ \\
\hline 2001 & 655 & 97.0 & -- & -- & -- & $6.32 \mathrm{E}+00$ & $7.19 \mathrm{E}+00$ & $6.74 \mathrm{E}+00$ \\
\hline 2002 & 1,154 & 97.0 & -- & -- & -- & $1.13 \mathrm{E}+01$ & $1.25 \mathrm{E}+01$ & $1.19 \mathrm{E}+01$ \\
\hline 2003 & 1,498 & 97.0 & -- & -- & -- & $1.48 \mathrm{E}+01$ & $1.61 \mathrm{E}+01$ & $1.54 \mathrm{E}+01$ \\
\hline 2004 & 368 & 97.3 & -- & -- & -- & $3.47 \mathrm{E}+00$ & $4.13 \mathrm{E}+00$ & $3.79 \mathrm{E}+00$ \\
\hline 2005 & 243 & 97.0 & -- & -- & -- & $2.25 \mathrm{E}+00$ & $2.79 \mathrm{E}+00$ & $2.51 \mathrm{E}+00$ \\
\hline 2006 & 242 & 97.0 & -- & -- & -- & $2.24 \mathrm{E}+00$ & $2.78 \mathrm{E}+00$ & $2.50 \mathrm{E}+00$ \\
\hline 2007 & 256 & 97.6 & -- & -- & -- & $2.36 \mathrm{E}+00$ & $2.91 \mathrm{E}+00$ & $2.63 \mathrm{E}+00$ \\
\hline 2008 & 282 & 98.3 & -- & -- & -- & $2.59 \mathrm{E}+00$ & $3.16 \mathrm{E}+00$ & $2.87 \mathrm{E}+00$ \\
\hline 2009 & 332 & 98.0 & $3.61 \mathrm{E}+00$ & $2.91 \mathrm{E}+00$ & $4.47 \mathrm{E}+00$ & $3.09 \mathrm{E}+00$ & $3.71 \mathrm{E}+00$ & $3.39 \mathrm{E}+00$ \\
\hline 2010 & 321 & 98.0 & $3.55 \mathrm{E}+00$ & $2.96 \mathrm{E}+00$ & $4.26 \mathrm{E}+00$ & $2.98 \mathrm{E}+00$ & $3.59 \mathrm{E}+00$ & $3.27 \mathrm{E}+00$ \\
\hline 2011 & 419 & 98.0 & $3.49 \mathrm{E}+00$ & $2.99 \mathrm{E}+00$ & $4.07 \mathrm{E}+00$ & $3.93 \mathrm{E}+00$ & $4.63 \mathrm{E}+00$ & $4.27 \mathrm{E}+00$ \\
\hline 2012 & 301 & 98.3 & $3.43 \mathrm{E}+00$ & $3.01 \mathrm{E}+00$ & $3.91 \mathrm{E}+00$ & $2.78 \mathrm{E}+00$ & $3.37 \mathrm{E}+00$ & $3.06 \mathrm{E}+00$ \\
\hline 2013 & 331 & 95.6 & $3.37 \mathrm{E}+00$ & $2.99 \mathrm{E}+00$ & $3.80 \mathrm{E}+00$ & $3.15 \mathrm{E}+00$ & $3.79 \mathrm{E}+00$ & $3.46 \mathrm{E}+00$ \\
\hline 2014 & 317 & 94.0 & $3.32 \mathrm{E}+00$ & $2.93 \mathrm{E}+00$ & $3.75 \mathrm{E}+00$ & $3.06 \mathrm{E}+00$ & $3.70 \mathrm{E}+00$ & $3.37 \mathrm{E}+00$ \\
\hline 2015 & 286 & 93.0 & $3.26 \mathrm{E}+00$ & $2.84 \mathrm{E}+00$ & $3.75 \mathrm{E}+00$ & $2.78 \mathrm{E}+00$ & $3.39 \mathrm{E}+00$ & $3.07 \mathrm{E}+00$ \\
\hline 2016 & 368 & 93.0 & $3.21 \mathrm{E}+00$ & $2.72 \mathrm{E}+00$ & $3.78 \mathrm{E}+00$ & $3.62 \mathrm{E}+00$ & $4.31 \mathrm{E}+00$ & $3.96 \mathrm{E}+00$ \\
\hline 2017 & 326 & 92.0 & $3.16 \mathrm{E}+00$ & $2.60 \mathrm{E}+00$ & $3.84 \mathrm{E}+00$ & $3.23 \mathrm{E}+00$ & $3.89 \mathrm{E}+00$ & $3.55 \mathrm{E}+00$ \\
\hline 2018 & 222 & 92.0 & $3.10 \mathrm{E}+00$ & $2.47 \mathrm{E}+00$ & $3.91 \mathrm{E}+00$ & $2.15 \mathrm{E}+00$ & $2.69 \mathrm{E}+00$ & $2.41 \mathrm{E}+00$ \\
\hline Total & 11,636 & $2,021.3$ & & & & & & \\
\hline
\end{tabular}


Table 20. Plot data for Figure 12, frequency of FTS events (events per reactor year) trend for standby TDPs.

\begin{tabular}{|c|c|c|c|c|c|c|c|c|}
\hline \multirow[b]{2}{*}{ Year } & \multirow[b]{2}{*}{ Failures } & \multirow[b]{2}{*}{$\begin{array}{c}\text { Reactor } \\
\text { Years }\end{array}$} & \multicolumn{3}{|c|}{ Regression Curve Data Points } & \multicolumn{3}{|c|}{ Yearly Estimate Data Points } \\
\hline & & & Mean & $\begin{array}{c}\text { Lower } \\
(5 \%)\end{array}$ & $\begin{array}{l}\text { Upper } \\
(95 \%) \\
\end{array}$ & $\begin{array}{c}\text { Lower } \\
(5 \%)\end{array}$ & $\begin{array}{l}\text { Upper } \\
(95 \%) \\
\end{array}$ & Mean \\
\hline 1998 & 2 & 97.0 & -- & -- & -- & 5.55E-03 & 6.82E-02 & 2.42E-02 \\
\hline 1999 & 12 & 97.0 & -- & -- & -- & 7.08E-02 & $1.94 \mathrm{E}-01$ & 1.21E-01 \\
\hline 2000 & 12 & 97.3 & -- & -- & -- & 7.07E-02 & 1.94E-01 & $1.21 \mathrm{E}-01$ \\
\hline 2001 & 5 & 97.0 & -- & -- & -- & 2.22E-02 & $1.08 \mathrm{E}-01$ & 5.33E-02 \\
\hline 2002 & 4 & 97.0 & -- & -- & -- & $1.61 \mathrm{E}-02$ & 9.54E-02 & 4.36E-02 \\
\hline 2003 & 8 & 97.0 & -- & -- & -- & 4.20E-02 & $1.46 \mathrm{E}-01$ & 8.24E-02 \\
\hline 2004 & 10 & 97.3 & -- & -- & -- & 5.60E-02 & 1.70E-01 & $1.02 \mathrm{E}-01$ \\
\hline 2005 & 6 & 97.0 & -- & -- & -- & 2.86E-02 & $1.21 \mathrm{E}-01$ & 6.30E-02 \\
\hline 2006 & 9 & 97.0 & -- & -- & -- & 4.90E-02 & $1.58 \mathrm{E}-01$ & $9.21 \mathrm{E}-02$ \\
\hline 2007 & 7 & 97.6 & -- & -- & -- & 3.50E-02 & $1.33 \mathrm{E}-01$ & 7.23E-02 \\
\hline 2008 & 12 & 98.3 & -- & -- & -- & 7.00E-02 & $1.92 \mathrm{E}-01$ & $1.20 \mathrm{E}-01$ \\
\hline 2009 & 12 & 98.0 & 1.11E-01 & 6.53E-02 & 1.89E-01 & 7.02E-02 & 1.93E-01 & 1.20E-01 \\
\hline 2010 & 9 & 98.0 & $1.01 \mathrm{E}-01$ & 6.47E-02 & $1.58 \mathrm{E}-01$ & 4.86E-02 & $1.57 \mathrm{E}-01$ & $9.12 \mathrm{E}-02$ \\
\hline 2011 & 9 & 98.0 & $9.21 \mathrm{E}-02$ & 6.33E-02 & 1.34E-01 & 4.86E-02 & $1.57 \mathrm{E}-01$ & $9.12 \mathrm{E}-02$ \\
\hline 2012 & 6 & 98.3 & 8.39E-02 & 6.04E-02 & 1.17E-01 & 2.82E-02 & $1.20 \mathrm{E}-01$ & $6.23 \mathrm{E}-02$ \\
\hline 2013 & 8 & 95.6 & 7.65E-02 & 5.56E-02 & $1.05 \mathrm{E}-01$ & 4.26E-02 & $1.48 \mathrm{E}-01$ & 8.36E-02 \\
\hline 2014 & 12 & 94.0 & 6.97E-02 & 4.93E-02 & 9.84E-02 & 7.30E-02 & 2.00E-01 & $1.25 \mathrm{E}-01$ \\
\hline 2015 & 3 & 93.0 & 6.35E-02 & 4.24E-02 & 9.50E-02 & 1.09E-02 & 8.53E-02 & $3.53 \mathrm{E}-02$ \\
\hline 2016 & 9 & 93.0 & 5.78E-02 & 3.57E-02 & 9.36E-02 & 5.10E-02 & 1.65E-01 & 9.58E-02 \\
\hline 2017 & 7 & 92.0 & 5.27E-02 & 2.98E-02 & 9.33E-02 & 3.70E-02 & $1.41 \mathrm{E}-01$ & 7.64E-02 \\
\hline 2018 & 2 & 92.0 & 4.80E-02 & 2.46E-02 & 9.36E-02 & 5.84E-03 & 7.17E-02 & $2.55 \mathrm{E}-02$ \\
\hline Total & 164 & $2,021.3$ & & & & & & \\
\hline
\end{tabular}


Table 21. Plot data for Figure 13, frequency of FTR $\leq 1$ H events (events per reactor year) trend for standby TDPs.

\begin{tabular}{|c|c|c|c|c|c|c|c|c|}
\hline \multirow[b]{2}{*}{ Year } & \multirow[b]{2}{*}{ Failures } & \multirow[b]{2}{*}{$\begin{array}{c}\text { Reactor } \\
\text { Years }\end{array}$} & \multicolumn{3}{|c|}{ Regression Curve Data Points } & \multicolumn{3}{|c|}{ Yearly Estimate Data Points } \\
\hline & & & Mean & $\begin{array}{c}\text { Lower } \\
(5 \%)\end{array}$ & $\begin{array}{l}\text { Upper } \\
(95 \%) \\
\end{array}$ & $\begin{array}{c}\text { Lower } \\
(5 \%)\end{array}$ & $\begin{array}{l}\text { Upper } \\
(95 \%) \\
\end{array}$ & Mean \\
\hline 1998 & 2 & 97.0 & -- & -- & -- & 4.95E-03 & 6.08E-02 & 2.16E-02 \\
\hline 1999 & 3 & 97.0 & -- & -- & -- & 9.37E-03 & 7.31E-02 & 3.03E-02 \\
\hline 2000 & 10 & 97.3 & -- & -- & -- & 5.00E-02 & $1.52 E-01$ & 9.06E-02 \\
\hline 2001 & 4 & 97.0 & -- & -- & -- & 1.44E-02 & $8.51 \mathrm{E}-02$ & 3.89E-02 \\
\hline 2002 & 5 & 97.0 & -- & -- & -- & 1.98E-02 & 9.67E-02 & 4.76E-02 \\
\hline 2003 & 8 & 97.0 & -- & -- & -- & $3.75 \mathrm{E}-02$ & $1.30 \mathrm{E}-01$ & 7.35E-02 \\
\hline 2004 & 0 & 97.3 & -- & -- & -- & 1.70E-05 & 3.37E-02 & 4.31E-03 \\
\hline 2005 & 4 & 97.0 & -- & -- & -- & 1.44E-02 & 8.51E-02 & 3.89E-02 \\
\hline 2006 & 2 & 97.0 & -- & -- & -- & 4.95E-03 & 6.08E-02 & 2.16E-02 \\
\hline 2007 & 7 & 97.6 & -- & -- & -- & 3.12E-02 & 1.19E-01 & $6.45 \mathrm{E}-02$ \\
\hline 2008 & 4 & 98.3 & -- & -- & -- & 1.42E-02 & 8.41E-02 & $3.85 \mathrm{E}-02$ \\
\hline 2009 & 5 & 98.0 & 2.96E-02 & 8.68E-03 & 1.01E-01 & 1.96E-02 & 9.58E-02 & 4.71E-02 \\
\hline 2010 & 3 & 98.0 & 2.71E-02 & 9.62E-03 & 7.62E-02 & 9.29E-03 & 7.25E-02 & $3.00 \mathrm{E}-02$ \\
\hline 2011 & 4 & 98.0 & 2.48E-02 & 1.04E-02 & 5.92E-02 & 1.43E-02 & 8.43E-02 & 3.86E-02 \\
\hline 2012 & 1 & 98.3 & 2.27E-02 & 1.07E-02 & 4.82E-02 & $1.50 \mathrm{E}-03$ & 4.73E-02 & $1.28 \mathrm{E}-02$ \\
\hline 2013 & 0 & 95.6 & 2.07E-02 & 1.02E-02 & 4.22E-02 & 1.72E-05 & 3.42E-02 & 4.38E-03 \\
\hline 2014 & 1 & 94.0 & $1.90 \mathrm{E}-02$ & 8.96E-03 & 4.01E-02 & 1.56E-03 & 4.91E-02 & 1.33E-02 \\
\hline 2015 & 4 & 93.0 & 1.73E-02 & 7.33E-03 & 4.11E-02 & 1.49E-02 & 8.81E-02 & 4.03E-02 \\
\hline 2016 & 4 & 93.0 & 1.59E-02 & 5.70E-03 & 4.41E-02 & 1.49E-02 & 8.81E-02 & 4.03E-02 \\
\hline 2017 & 0 & 92.0 & 1.45E-02 & 4.31E-03 & 4.89E-02 & 1.78E-05 & 3.53E-02 & 4.52E-03 \\
\hline 2018 & 3 & 92.0 & 1.33E-02 & 3.20E-03 & 5.51E-02 & 9.79E-03 & 7.64E-02 & 3.16E-02 \\
\hline Total & 74 & $2,021.3$ & & & & & & \\
\hline
\end{tabular}


Table 22. Plot data for Figure 14, frequency of FTR $>1$ H events (events per reactor year) trend for standby TDPs.

\begin{tabular}{|c|c|c|c|c|c|c|c|c|}
\hline \multirow[b]{2}{*}{ Year } & \multirow[b]{2}{*}{ Failures } & \multirow[b]{2}{*}{$\begin{array}{c}\text { Reactor } \\
\text { Years }\end{array}$} & \multicolumn{3}{|c|}{ Regression Curve Data Points } & \multicolumn{3}{|c|}{ Yearly Estimate Data Points } \\
\hline & & & Mean & $\begin{array}{c}\text { Lower } \\
(5 \%)\end{array}$ & $\begin{array}{l}\text { Upper } \\
(95 \%)\end{array}$ & $\begin{array}{c}\text { Lower } \\
(5 \%)\end{array}$ & $\begin{array}{l}\text { Upper } \\
(95 \%)\end{array}$ & Mean \\
\hline 1998 & 0 & 97.0 & -- & -- & -- & 1.68E-05 & 3.33E-02 & 4.26E-03 \\
\hline 1999 & 1 & 97.0 & -- & -- & -- & $1.50 \mathrm{E}-03$ & 4.72E-02 & $1.28 \mathrm{E}-02$ \\
\hline 2000 & 3 & 97.3 & -- & -- & -- & $9.22 E-03$ & 7.20E-02 & 2.98E-02 \\
\hline 2001 & 1 & 97.0 & -- & -- & -- & $1.50 \mathrm{E}-03$ & 4.72E-02 & $1.28 \mathrm{E}-02$ \\
\hline 2002 & 0 & 97.0 & -- & -- & -- & 1.68E-05 & 3.33E-02 & 4.26E-03 \\
\hline 2003 & 1 & 97.0 & -- & -- & -- & $1.50 \mathrm{E}-03$ & 4.72E-02 & $1.28 \mathrm{E}-02$ \\
\hline 2004 & 4 & 97.3 & -- & -- & -- & 1.41E-02 & 8.37E-02 & 3.83E-02 \\
\hline 2005 & 3 & 97.0 & -- & -- & -- & $9.24 \mathrm{E}-03$ & 7.21E-02 & 2.99E-02 \\
\hline 2006 & 0 & 97.0 & -- & -- & -- & 1.68E-05 & 3.33E-02 & 4.26E-03 \\
\hline 2007 & 1 & 97.6 & -- & -- & -- & 1.49E-03 & 4.70E-02 & 1.27E-02 \\
\hline 2008 & 2 & 98.3 & -- & -- & -- & 4.83E-03 & 5.93E-02 & $2.11 \mathrm{E}-02$ \\
\hline 2009 & 0 & 98.0 & $1.51 \mathrm{E}-02$ & 6.03E-03 & 3.81E-02 & 1.66E-05 & 3.30E-02 & $4.23 \mathrm{E}-03$ \\
\hline 2010 & 1 & 98.0 & 1.63E-02 & 7.44E-03 & 3.57E-02 & 1.49E-03 & 4.68E-02 & 1.27E-02 \\
\hline 2011 & 4 & 98.0 & 1.76E-02 & 9.07E-03 & 3.40E-02 & 1.41E-02 & 8.32E-02 & 3.81E-02 \\
\hline 2012 & 4 & 98.3 & $1.89 \mathrm{E}-02$ & $1.08 \mathrm{E}-02$ & 3.30E-02 & 1.40E-02 & 8.30E-02 & $3.80 \mathrm{E}-02$ \\
\hline 2013 & 3 & 95.6 & 2.04E-02 & 1.25E-02 & 3.32E-02 & 9.36E-03 & 7.30E-02 & 3.02E-02 \\
\hline 2014 & 3 & 94.0 & 2.19E-02 & 1.37E-02 & 3.51E-02 & $9.49 \mathrm{E}-03$ & 7.40E-02 & 3.06E-02 \\
\hline 2015 & 2 & 93.0 & 2.36E-02 & 1.42E-02 & 3.92E-02 & 5.06E-03 & 6.21E-02 & $2.21 \mathrm{E}-02$ \\
\hline 2016 & 2 & 93.0 & 2.54E-02 & 1.41E-02 & 4.59E-02 & 5.06E-03 & 6.21E-02 & $2.21 \mathrm{E}-02$ \\
\hline 2017 & 2 & 92.0 & 2.73E-02 & 1.35E-02 & 5.52E-02 & 5.10E-03 & 6.27E-02 & 2.23E-02 \\
\hline 2018 & 2 & 92.0 & 2.94E-02 & 1.28E-02 & 6.76E-02 & $5.10 \mathrm{E}-03$ & 6.27E-02 & 2.23E-02 \\
\hline Total & 39 & $2,021.3$ & & & & & & \\
\hline
\end{tabular}


Table 23. Plot data for Figure 15, frequency of start demands (demands per reactor year) trend for normally running TDPs.

\begin{tabular}{|c|c|c|c|c|c|c|c|c|}
\hline \multirow[b]{2}{*}{ Year } & \multirow[b]{2}{*}{ Demands } & \multirow[b]{2}{*}{$\begin{array}{c}\text { Reactor } \\
\text { Years }\end{array}$} & \multicolumn{3}{|c|}{ Regression Curve Data Points } & \multicolumn{3}{|c|}{ Yearly Estimate Data Points } \\
\hline & & & Mean & $\begin{array}{l}\text { Lower } \\
\text { (5\%) }\end{array}$ & $\begin{array}{l}\text { Upper } \\
\text { (95\%) }\end{array}$ & $\begin{array}{c}\text { Lower } \\
(5 \%)\end{array}$ & $\begin{array}{l}\text { Upper } \\
(95 \%)\end{array}$ & Mean \\
\hline 1998 & 79 & 29.0 & -- & -- & -- & $2.23 \mathrm{E}+00$ & $3.27 E+00$ & $2.71 \mathrm{E}+00$ \\
\hline 1999 & 79 & 29.0 & -- & -- & -- & $2.23 E+00$ & $3.27 E+00$ & $2.71 E+00$ \\
\hline 2000 & 79 & 29.1 & -- & -- & -- & $2.23 E+00$ & $3.26 \mathrm{E}+00$ & $2.71 \mathrm{E}+00$ \\
\hline 2001 & 78 & 29.0 & -- & -- & -- & $2.22 \mathrm{E}+00$ & $3.25 \mathrm{E}+00$ & $2.70 \mathrm{E}+00$ \\
\hline 2002 & 78 & 29.0 & -- & -- & -- & $2.22 \mathrm{E}+00$ & $3.25 \mathrm{E}+00$ & $2.70 \mathrm{E}+00$ \\
\hline 2003 & 78 & 29.0 & -- & -- & -- & $2.21 \mathrm{E}+00$ & $3.25 \mathrm{E}+00$ & $2.69 \mathrm{E}+00$ \\
\hline 2004 & 78 & 29.1 & -- & -- & -- & $2.22 \mathrm{E}+00$ & $3.25 \mathrm{E}+00$ & $2.70 \mathrm{E}+00$ \\
\hline 2005 & 78 & 29.0 & -- & -- & -- & $2.21 \mathrm{E}+00$ & $3.24 \mathrm{E}+00$ & $2.69 \mathrm{E}+00$ \\
\hline 2006 & 78 & 29.0 & -- & -- & -- & $2.22 \mathrm{E}+00$ & $3.25 E+00$ & $2.70 \mathrm{E}+00$ \\
\hline 2007 & 78 & 29.0 & -- & -- & -- & $2.21 \mathrm{E}+00$ & $3.25 \mathrm{E}+00$ & $2.69 E+00$ \\
\hline 2008 & 78 & 29.1 & -- & -- & -- & $2.21 \mathrm{E}+00$ & $3.24 \mathrm{E}+00$ & $2.68 \mathrm{E}+00$ \\
\hline 2009 & 78 & 29.0 & $2.64 \mathrm{E}+00$ & $2.62 E+00$ & $2.66 \mathrm{E}+00$ & $2.19 \mathrm{E}+00$ & $3.23 E+00$ & 2.67E+00 \\
\hline 2010 & 76 & 29.0 & $2.64 \mathrm{E}+00$ & $2.62 E+00$ & $2.66 \mathrm{E}+00$ & $2.16 \mathrm{E}+00$ & $3.18 \mathrm{E}+00$ & $2.63 \mathrm{E}+00$ \\
\hline 2011 & 76 & 29.0 & $2.63 E+00$ & $2.62 \mathrm{E}+00$ & $2.65 E+00$ & $2.15 \mathrm{E}+00$ & $3.17 \mathrm{E}+00$ & $2.62 E+00$ \\
\hline 2012 & 76 & 29.1 & $2.63 \mathrm{E}+00$ & $2.62 \mathrm{E}+00$ & $2.64 \mathrm{E}+00$ & $2.14 \mathrm{E}+00$ & $3.16 \mathrm{E}+00$ & $2.62 E+00$ \\
\hline 2013 & 76 & 29.0 & $2.63 E+00$ & $2.62 \mathrm{E}+00$ & $2.64 \mathrm{E}+00$ & $2.15 \mathrm{E}+00$ & $3.18 \mathrm{E}+00$ & $2.63 E+00$ \\
\hline 2014 & 76 & 29.0 & $2.63 E+00$ & $2.61 \mathrm{E}+00$ & $2.64 E+00$ & $2.15 \mathrm{E}+00$ & $3.17 \mathrm{E}+00$ & $2.62 E+00$ \\
\hline 2015 & 76 & 29.0 & $2.62 \mathrm{E}+00$ & $2.61 \mathrm{E}+00$ & $2.64 E+00$ & $2.15 \mathrm{E}+00$ & $3.17 \mathrm{E}+00$ & $2.63 E+00$ \\
\hline 2016 & 76 & 29.1 & $2.62 \mathrm{E}+00$ & $2.61 \mathrm{E}+00$ & $2.64 \mathrm{E}+00$ & $2.15 \mathrm{E}+00$ & $3.17 \mathrm{E}+00$ & $2.62 E+00$ \\
\hline 2017 & 76 & 29.0 & $2.62 \mathrm{E}+00$ & $2.60 \mathrm{E}+00$ & $2.64 \mathrm{E}+00$ & $2.16 \mathrm{E}+00$ & $3.18 \mathrm{E}+00$ & $2.63 \mathrm{E}+00$ \\
\hline 2018 & 76 & 29.0 & $2.61 \mathrm{E}+00$ & $2.59 \mathrm{E}+00$ & $2.64 \mathrm{E}+00$ & $2.15 \mathrm{E}+00$ & $3.17 \mathrm{E}+00$ & $2.62 E+00$ \\
\hline Total & 1,624 & 609.4 & & & & & & \\
\hline
\end{tabular}


Table 24. Plot data for Figure 16, frequency of run hours (hours per reactor year) trend for normally running TDPS.

\begin{tabular}{cccccccccc}
\hline & & & \multicolumn{2}{c}{ Regression Curve Data Points } & \multicolumn{2}{c}{ Yearly Estimate Data Points } \\
\cline { 7 - 10 } Year & $\begin{array}{c}\text { Run } \\
\text { Hours }\end{array}$ & $\begin{array}{c}\text { Reactor } \\
\text { Years }\end{array}$ & Mean & $\begin{array}{c}\text { Lower } \\
\mathbf{( 5 \% )}\end{array}$ & $\begin{array}{c}\text { Upper } \\
\mathbf{( 9 5 \% )}\end{array}$ & $\begin{array}{c}\text { Lower } \\
\mathbf{( 5 \% )}\end{array}$ & $\begin{array}{c}\text { Upper } \\
\mathbf{( 9 5 \% )}\end{array}$ & Mean \\
\hline 1998 & 335,022 & 29.0 & -- & -- & -- & $1.15 \mathrm{E}+04$ & $1.16 \mathrm{E}+04$ & $1.16 \mathrm{E}+04$ \\
\hline 1999 & 335,022 & 29.0 & -- & -- & -- & $1.15 \mathrm{E}+04$ & $1.16 \mathrm{E}+04$ & $1.16 \mathrm{E}+04$ \\
\hline 2000 & 335,022 & 29.1 & -- & -- & -- & $1.15 \mathrm{E}+04$ & $1.16 \mathrm{E}+04$ & $1.15 \mathrm{E}+04$ \\
\hline 2001 & 335,432 & 29.0 & -- & -- & -- & $1.15 \mathrm{E}+04$ & $1.16 \mathrm{E}+04$ & $1.16 \mathrm{E}+04$ \\
\hline 2002 & 335,387 & 29.0 & -- & -- & -- & $1.15 \mathrm{E}+04$ & $1.16 \mathrm{E}+04$ & $1.16 \mathrm{E}+04$ \\
\hline 2003 & 335,371 & 29.0 & -- & -- & -- & $1.15 \mathrm{E}+04$ & $1.16 \mathrm{E}+04$ & $1.16 \mathrm{E}+04$ \\
\hline 2004 & 335,356 & 29.1 & -- & -- & -- & $1.15 \mathrm{E}+04$ & $1.16 \mathrm{E}+04$ & $1.15 \mathrm{E}+04$ \\
\hline 2005 & 335,417 & 29.0 & -- & -- & -- & $1.15 \mathrm{E}+04$ & $1.16 \mathrm{E}+04$ & $1.16 \mathrm{E}+04$ \\
\hline 2006 & 335,463 & 29.0 & -- & -- & -- & $1.15 \mathrm{E}+04$ & $1.16 \mathrm{E}+04$ & $1.16 \mathrm{E}+04$ \\
\hline 2007 & 335,326 & 29.0 & -- & -- & -- & $1.15 \mathrm{E}+04$ & $1.16 \mathrm{E}+04$ & $1.16 \mathrm{E}+04$ \\
\hline 2008 & 335,387 & 29.1 & -- & -- & -- & $1.15 \mathrm{E}+04$ & $1.16 \mathrm{E}+04$ & $1.15 \mathrm{E}+04$ \\
\hline 2009 & 333,274 & 29.0 & $1.14 \mathrm{E}+04$ & $1.13 \mathrm{E}+04$ & $1.14 \mathrm{E}+04$ & $1.15 \mathrm{E}+04$ & $1.15 \mathrm{E}+04$ & $1.15 \mathrm{E}+04$ \\
\hline 2010 & 327,318 & 29.0 & $1.13 \mathrm{E}+04$ & $1.13 \mathrm{E}+04$ & $1.14 \mathrm{E}+04$ & $1.13 \mathrm{E}+04$ & $1.13 \mathrm{E}+04$ & $1.13 \mathrm{E}+04$ \\
\hline 2011 & 327,181 & 29.0 & $1.13 \mathrm{E}+04$ & $1.13 \mathrm{E}+04$ & $1.14 \mathrm{E}+04$ & $1.13 \mathrm{E}+04$ & $1.13 \mathrm{E}+04$ & $1.13 \mathrm{E}+04$ \\
\hline 2012 & 327,166 & 29.1 & $1.13 \mathrm{E}+04$ & $1.13 \mathrm{E}+04$ & $1.14 \mathrm{E}+04$ & $1.12 \mathrm{E}+04$ & $1.13 \mathrm{E}+04$ & $1.13 \mathrm{E}+04$ \\
\hline 2013 & 327,089 & 29.0 & $1.13 \mathrm{E}+04$ & $1.13 \mathrm{E}+04$ & $1.14 \mathrm{E}+04$ & $1.12 \mathrm{E}+04$ & $1.13 \mathrm{E}+04$ & $1.13 \mathrm{E}+04$ \\
\hline 2014 & 327,257 & 29.0 & $1.13 \mathrm{E}+04$ & $1.12 \mathrm{E}+04$ & $1.13 \mathrm{E}+04$ & $1.13 \mathrm{E}+04$ & $1.13 \mathrm{E}+04$ & $1.13 \mathrm{E}+04$ \\
\hline 2015 & 327,196 & 29.0 & $1.13 \mathrm{E}+04$ & $1.12 \mathrm{E}+04$ & $1.13 \mathrm{E}+04$ & $1.13 \mathrm{E}+04$ & $1.13 \mathrm{E}+04$ & $1.13 \mathrm{E}+04$ \\
\hline 2016 & 327,196 & 29.1 & $1.13 \mathrm{E}+04$ & $1.12 \mathrm{E}+04$ & $1.13 \mathrm{E}+04$ & $1.12 \mathrm{E}+04$ & $1.13 \mathrm{E}+04$ & $1.13 \mathrm{E}+04$ \\
\hline 2017 & 327,074 & 29.0 & $1.13 \mathrm{E}+04$ & $1.12 \mathrm{E}+04$ & $1.13 \mathrm{E}+04$ & $1.12 \mathrm{E}+04$ & $1.13 \mathrm{E}+04$ & $1.13 \mathrm{E}+04$ \\
\hline 2018 & 327,272 & 29.0 & $1.12 \mathrm{E}+04$ & $1.12 \mathrm{E}+04$ & $1.13 \mathrm{E}+04$ & $1.13 \mathrm{E}+04$ & $1.13 \mathrm{E}+04$ & $1.13 \mathrm{E}+04$ \\
\hline Total & $6,966,227$ & 609.4 & & & & & & & \\
\hline
\end{tabular}


Table 25. Plot data for Figure 17, frequency of FTS events (events per reactor year) trend for normally running TDPs.

\begin{tabular}{|c|c|c|c|c|c|c|c|c|}
\hline \multirow[b]{2}{*}{ Year } & \multirow[b]{2}{*}{ Failures } & \multirow[b]{2}{*}{$\begin{array}{c}\text { Reactor } \\
\text { Years }\end{array}$} & \multicolumn{3}{|c|}{ Regression Curve Data Points } & \multicolumn{3}{|c|}{ Yearly Estimate Data Points } \\
\hline & & & Mean & $\begin{array}{c}\text { Lower } \\
\mathbf{( 5 \% )}\end{array}$ & $\begin{array}{l}\text { Upper } \\
(95 \%) \\
\end{array}$ & $\begin{array}{c}\text { Lower } \\
(5 \%)\end{array}$ & $\begin{array}{l}\text { Upper } \\
(95 \%) \\
\end{array}$ & Mean \\
\hline 1998 & 2 & 29.0 & -- & -- & -- & 9.35E-03 & $1.15 \mathrm{E}-01$ & $4.08 \mathrm{E}-02$ \\
\hline 1999 & 2 & 29.0 & -- & -- & -- & 9.35E-03 & 1.15E-01 & 4.08E-02 \\
\hline 2000 & 0 & 29.1 & -- & -- & -- & 3.21E-05 & 6.37E-02 & 8.15E-03 \\
\hline 2001 & 1 & 29.0 & -- & -- & -- & 2.87E-03 & $9.04 \mathrm{E}-02$ & $2.45 \mathrm{E}-02$ \\
\hline 2002 & 0 & 29.0 & -- & -- & -- & 3.21E-05 & 6.38E-02 & 8.16E-03 \\
\hline 2003 & 0 & 29.0 & -- & -- & -- & 3.21E-05 & $6.38 \mathrm{E}-02$ & 8.16E-03 \\
\hline 2004 & 0 & 29.1 & -- & -- & -- & 3.21E-05 & 6.37E-02 & $8.15 E-03$ \\
\hline 2005 & 3 & 29.0 & -- & -- & -- & 1.77E-02 & 1.38E-01 & 5.72E-02 \\
\hline 2006 & 1 & 29.0 & -- & -- & -- & 2.87E-03 & 9.04E-02 & $2.45 \mathrm{E}-02$ \\
\hline 2007 & 0 & 29.0 & -- & -- & -- & 3.21E-05 & 6.38E-02 & 8.16E-03 \\
\hline 2008 & 0 & 29.1 & -- & -- & -- & 3.21E-05 & 6.37E-02 & $8.15 \mathrm{E}-03$ \\
\hline 2009 & 1 & 29.0 & 1.61E-02 & 6.89E-03 & 3.78E-02 & 2.87E-03 & 9.04E-02 & $2.45 \mathrm{E}-02$ \\
\hline 2010 & 0 & 29.0 & 1.53E-02 & 7.43E-03 & 3.15E-02 & 3.21E-05 & 6.38E-02 & 8.16E-03 \\
\hline 2011 & 0 & 29.0 & 1.45E-02 & 7.89E-03 & 2.66E-02 & 3.21E-05 & 6.38E-02 & 8.16E-03 \\
\hline 2012 & 1 & 29.1 & 1.37E-02 & 8.19E-03 & $2.30 \mathrm{E}-02$ & 2.87E-03 & 9.03E-02 & $2.45 \mathrm{E}-02$ \\
\hline 2013 & 1 & 29.0 & 1.30E-02 & 8.19E-03 & 2.07E-02 & 2.87E-03 & 9.04E-02 & $2.45 \mathrm{E}-02$ \\
\hline 2014 & 0 & 29.0 & 1.23E-02 & 7.79E-03 & 1.95E-02 & 3.21E-05 & 6.38E-02 & 8.16E-03 \\
\hline 2015 & 0 & 29.0 & 1.17E-02 & 7.04E-03 & 1.94E-02 & 3.21E-05 & 6.38E-02 & 8.16E-03 \\
\hline 2016 & 1 & 29.1 & 1.11E-02 & 6.11E-03 & 2.00E-02 & 2.87E-03 & 9.03E-02 & $2.45 \mathrm{E}-02$ \\
\hline 2017 & 0 & 29.0 & 1.05E-02 & 5.18E-03 & 2.12E-02 & 3.21E-05 & 6.38E-02 & 8.16E-03 \\
\hline 2018 & 0 & 29.0 & 9.93E-03 & 4.32E-03 & $2.28 \mathrm{E}-02$ & 3.21E-05 & 6.38E-02 & 8.16E-03 \\
\hline Total & 13 & 609.4 & & & & & & \\
\hline
\end{tabular}


Table 26. Plot data for Figure 18, frequency of FTR events (events per reactor year) trend for normally running TDPs.

\begin{tabular}{|c|c|c|c|c|c|c|c|c|}
\hline \multirow[b]{2}{*}{ Year } & \multirow[b]{2}{*}{ Failures } & \multirow[b]{2}{*}{$\begin{array}{l}\text { Reactor } \\
\text { Years }\end{array}$} & \multicolumn{3}{|c|}{ Regression Curve Data Points } & \multicolumn{3}{|c|}{ Yearly Estimate Data Points } \\
\hline & & & Mean & $\begin{array}{l}\text { Lower } \\
(5 \%)\end{array}$ & $\begin{array}{l}\text { Upper } \\
(95 \%)\end{array}$ & $\begin{array}{l}\text { Lower } \\
(5 \%)\end{array}$ & $\begin{array}{l}\text { Upper } \\
(95 \%)\end{array}$ & Mean \\
\hline 1998 & 1 & 29.0 & -- & -- & -- & 5.30E-03 & 1.67E-01 & 4.52E-02 \\
\hline 1999 & 6 & 29.0 & -- & -- & -- & 8.87E-02 & 3.76E-01 & 1.96E-01 \\
\hline 2000 & 2 & 29.1 & -- & -- & -- & 1.72E-02 & 2.11E-01 & 7.51E-02 \\
\hline 2001 & 3 & 29.0 & -- & -- & -- & 3.26E-02 & $2.55 \mathrm{E}-01$ & 1.05E-01 \\
\hline 2002 & 3 & 29.0 & -- & -- & -- & 3.26E-02 & $2.55 \mathrm{E}-01$ & 1.05E-01 \\
\hline 2003 & 6 & 29.0 & -- & -- & -- & 8.87E-02 & 3.76E-01 & 1.96E-01 \\
\hline 2004 & 3 & 29.1 & -- & -- & -- & 3.26E-02 & $2.54 \mathrm{E}-01$ & 1.05E-01 \\
\hline 2005 & 6 & 29.0 & -- & -- & -- & 8.87E-02 & 3.76E-01 & 1.96E-01 \\
\hline 2006 & 3 & 29.0 & -- & -- & -- & 3.26E-02 & $2.55 \mathrm{E}-01$ & 1.05E-01 \\
\hline 2007 & 3 & 29.0 & -- & -- & -- & 3.26E-02 & $2.55 \mathrm{E}-01$ & 1.05E-01 \\
\hline 2008 & 3 & 29.1 & -- & -- & -- & 3.26E-02 & $2.54 \mathrm{E}-01$ & 1.05E-01 \\
\hline 2009 & 3 & 29.0 & 1.39E-01 & 8.21E-02 & 2.35E-01 & 3.26E-02 & $2.55 \mathrm{E}-01$ & 1.05E-01 \\
\hline 2010 & 6 & 29.0 & $1.32 \mathrm{E}-01$ & 8.45E-02 & 2.05E-01 & 8.87E-02 & 3.76E-01 & 1.96E-01 \\
\hline 2011 & 2 & 29.0 & 1.25E-01 & 8.61E-02 & 1.82E-01 & 1.72E-02 & 2.12E-01 & 7.53E-02 \\
\hline 2012 & 6 & 29.1 & 1.19E-01 & 8.60E-02 & $1.64 \mathrm{E}-01$ & 8.85E-02 & 3.75E-01 & 1.95E-01 \\
\hline 2013 & 4 & 29.0 & 1.13E-01 & 8.36E-02 & $1.52 \mathrm{E}-01$ & 5.01E-02 & 2.96E-01 & 1.36E-01 \\
\hline 2014 & 2 & 29.0 & 1.07E-01 & 7.84E-02 & $1.45 \mathrm{E}-01$ & 1.72E-02 & 2.12E-01 & 7.53E-02 \\
\hline 2015 & 4 & 29.0 & $1.01 \mathrm{E}-01$ & 7.13E-02 & $1.44 \mathrm{E}-01$ & 5.01E-02 & 2.96E-01 & 1.36E-01 \\
\hline 2016 & 2 & 29.1 & 9.61E-02 & 6.34E-02 & $1.46 \mathrm{E}-01$ & 1.72E-02 & 2.11E-01 & 7.51E-02 \\
\hline 2017 & 3 & 29.0 & $9.12 \mathrm{E}-02$ & 5.56E-02 & $1.50 \mathrm{E}-01$ & 3.26E-02 & $2.55 \mathrm{E}-01$ & 1.05E-01 \\
\hline 2018 & 2 & 29.0 & 8.65E-02 & 4.84E-02 & $1.55 \mathrm{E}-01$ & 1.72E-02 & 2.12E-01 & 7.53E-02 \\
\hline Total & 73 & 609.4 & & & & & & \\
\hline
\end{tabular}




\section{REFERENCES}

[1] J. R. Houghton, H. G. Hamzehee, "Component Performance Study - Turbine-Driven Pumps, 19871998," NUREG-1715, Vol. 1, U.S. Nuclear Regulatory Commission, April 2000.

[2] J. A. Schroeder, "Enhanced Component Performance Study: Turbine-Driven Pumps 1998-2016," INL/EXT-17-44116, Idaho National laboratory, April 2018.

[3] C. D. Gentillion, "Overview and Reference Document for Operational Experience Results and Databases Trending," February 2016. [Online]. Available: https://nrcoe.inel.gov/resultsdb/publicdocs/Overview-and-Reference.pdf.

[4] J. C. Lane, "NRC Operating Experience (OpE) Programs," Office of Nuclear Regulatory Research, July 2015. [Online]. Available: http://pbadupws.nrc.gov/docs/ML1518/ML15189A345.pdf. [Accessed 2015].

[5] Nuclear Energy Institute, "Regulatory Assessment Performance Indicator Guideline," NEI 99-02, Revision 7, August 2013.

[6] United States Nuclear Regulatory Commission, "Component Reliability Data Sheets Update 2015," February 2017. [Online]. Available: http://nrcoe.inl.gov/resultsdb/publicdocs/AvgPerf/ComponentReliabilityDataSheets2015.pdf.

[7] S. A. Eide, T. E. Wierman, C. D. Gentillon, D. M. Rasmuson and C. L. Atwood, "Industry-Average Performance for Components and Initiating Events at U.S. Commercial Nuclear Power Plants," NUREG/CR-6928, U.S. Nuclear Regulatory Commission, February 2007.

[8] C. L. Atwood, etc., "Handbook of Parameter Estimation for Probabilistic Risk Assessment," NUREG/CR-6823, U.S. Nuclear Regulatory Commission, September 2003. 